\title{
Characterisation of NO production and consumption: new insights by an improved laboratory dynamic chamber technique
}

\author{
T. Behrendt ${ }^{1}$, P. R. Veres $^{2}$, F. Ashuri ${ }^{1}$, G. Song ${ }^{1,3}$, M. Flanz ${ }^{4}$, B. Mamtimin ${ }^{1}$, M. Bruse ${ }^{5}$, J. Williams ${ }^{4}$, and \\ F. X. Meixner ${ }^{1}$ \\ ${ }^{1}$ Biogeochemistry Department, Max Planck Institute for Chemistry, Mainz, Germany \\ ${ }^{2}$ Cooperative Institute for Research in Environmental Sciences, Boulder, CO 80305, USA \\ ${ }^{3}$ Institute of Applied Ecology, Chinese Academy of Sciences, Shenyang, P.R. China \\ ${ }^{4}$ Atmospheric Chemistry Department, Max Planck Institute for Chemistry, Mainz, Germany \\ ${ }^{5}$ Environmental Modelling Group (EMG), Johannes Gutenberg University Mainz, Mainz, Germany \\ Correspondence to: T. Behrendt (thomas.behrendt@mpic.de)
}

Received: 1 January 2014 - Published in Biogeosciences Discuss.: 17 January 2014

Revised: 15 July 2014 - Accepted: 28 August 2014 - Published: 8 October 2014

\begin{abstract}
Biogenic $\mathrm{NO}_{\mathrm{x}}$ emissions from natural and anthropogenically influenced soils are currently estimated to amount to $9 \mathrm{Tg} \mathrm{a}^{-1}$, hence a significant fraction of global $\mathrm{NO}_{\mathrm{x}}$ emissions $\left(45 \mathrm{Tg} \mathrm{a}^{-1}\right)$. During the last three decades, a large number of field measurements have been performed to quantify biogenic NO emissions. To study biogenic NO emissions as a function of soil moisture, soil temperature, and soil nutrients, several laboratory approaches have been developed to estimate local/regional NO emissions by suitable upscaling. This study presents an improved and automated laboratory dynamic chamber system (consisting of six individual soil chambers) for investigation and quantification of all quantities necessary to characterise biogenic NO release from soil (i.e. net NO release rate, NO production and consumption rate, and respective $Q_{10}$ values). In contrast to former versions of the laboratory dynamic chamber system, the four experiments for complete characterisation can now be performed on a single soil sample, whereas former studies had to be performed on four sub-samples. This study discovered that the sub-sample variability biased former measurements of net NO release rates tremendously. Furthermore, it was also shown that the previously reported variation of optimum soil moisture (i.e. where a maximum net NO release rates occur) between individual sub-samples is most likely a methodical artefact of former versions of the laboratory dynamic chamber system.
\end{abstract}

A comprehensive and detailed methodical concept description of the improved laboratory dynamic chamber system is provided. Response of all quantities (necessary to characterise net NO release) to soil temperature and NO mixing ratio of the flushing airstream are determined by automatic monitoring of these variables during one single dryingout experiment with one single soil sample only. The method requires precise measurements of $\mathrm{NO}$ mixing ratio at the inlet and outlet of each soil chamber; finally, four pairs of inlet/outlet NO mixing ratios are sufficient to derive all necessary quantities. Soil samples from drylands exhibit particularly low NO production, but even lower NO consumption rates. However, with the improved laboratory dynamic chamber system those low levels can be quantified, as well as corresponding NO compensation point mixing ratios and respective $Q_{10}$ values. It could be shown that the NO compensation point mixing ratio seems to be generally independent of gravimetric soil moisture content, but, particularly for dryland soils, strongly dependent on soil temperature.

New facilities have been included into the improved system (e.g. for investigation of net release rates of other trace gases, namely $\mathrm{CO}_{2}$ and volatile organic compounds - VOCs). First, results are shown for net release rates of acetone $\left(\mathrm{C}_{3} \mathrm{H}_{6} \mathrm{O}\right)$, acetaldehyde $\left(\mathrm{C}_{2} \mathrm{H}_{4} \mathrm{O}\right)$ and $\mathrm{CO}_{2}$. This new system is thus able to simultaneously investigate potential mechanistic links between NO, multitudinous VOC and $\mathrm{CO}_{2}$. 


\section{Introduction}

The turnover of nutrients in natural soils is predominantly driven by soil microbes and any control of production and consumption of trace gases in the soil is exerted on the level of microbes' metabolism. If production of the trace gas in the soil exceeds its consumption, the trace gas will be delivered to the atmosphere. In case of nitric oxide (NO), microbially produced NO is usually released from soils. Once in the atmosphere, it is immediately involved in important chemical reactions (Crutzen et al., 1999; Denman et al., 2007). It reacts with atmospheric oxidants $\left(\mathrm{O}_{3}, \mathrm{OH}, \mathrm{NO}_{3}^{*}\right)$ and is converted first to nitrogen dioxide $\left(\mathrm{NO}_{2}\right)$, and finally to nitric acid $\left(\mathrm{HNO}_{3}\right.$, Williams et al., 1992). The concentration of both, $\mathrm{NO}_{\mathrm{x}}\left(=\mathrm{NO}+\mathrm{NO}_{2}\right)$ and volatile organic compounds (VOCs), controls the production or destruction of tropospheric $\mathrm{O}_{3}$ with a production threshold of ca. $30 \mathrm{ppt}$ of $\mathrm{NO}$ (Sillman, 1999; Chameides et al., 1992). Particularly for understanding tropospheric chemistry of non-industrialised regions, it is important to know the strength of biogenic NO and VOCs emissions from natural sources. While there is rich literature with respect to soil biogenic NO emissions, relatively little is known about VOC emissions from and VOC deposition to soils.

The microbial release of NO from soils was first discovered by Galbally and Roy (1978). Underlying processes are nitrification and denitrification (Braker and Conrad, 2011). It is well known that microbes can release VOCs but the mechanisms are still unknown (Insam and Seewald, 2010; Schulz and Dickschat, 2007). Historically, it has been assumed that the function of inter- and intraspecies communication (quorum sensing) as well as defence play an important role in VOC production (Schulz and Dickschat, 2007). Since (i) emissions of NO and VOCs from soils are highly variable in space and time and (ii) corresponding field experiments are costly, laboratory incubation experiments are the ideal tool for studying mechanistic processes. Additionally, environmental conditions are usually highly variable in the field; consequently, identification and quantification of individual factors, which might influence soil biogenic NO and VOC (e.g. soil moisture, soil temperature, soil nutrients), is often impossible because of mutual masking effects.

Early pioneering studies of NO emission from soils found that - within the top soil layer - NO is microbially produced and consumed as an intermediate within the process of nitrification and denitrification (Gödde and Conrad, 1999; Conrad, 1996; Schuster and Conrad, 1992). The major enzymatic pathways which generate NO are autotrophic nitrification, heterotrophic nitrification, and denitrification (Braker and Conrad, 2011). The enzymes involved differ in their half saturation constants, $K_{\mathrm{m}}$, as well as in their maximum reaction rate, $V_{\max }$ (Koper et al., 2010, Betlach and Tiedje, 1981). In an earlier study (Kumon et al., 2002), co-denitrification of fungi, i.e. the formation of an N-product owing an oxidation number between the oxidation numbers of its educts, was found. It is still unclear how much this process contributes to the production and consumption of NO in soils. Within the process of dissimilatory nitrate reduction to ammonia (DNRA), $\mathrm{N}_{2} \mathrm{O}$ can be produced (Rütting et al., 2011). Since DNRA is the reverse process of nitrification, where $\mathrm{NO}$ and $\mathrm{N}_{2} \mathrm{O}$ can be produced, it might be possible that $\mathrm{NO}$ is formed, too. Besides the microbial production and consumption of NO, some abiotic processes are known that also result in the release of NO from soils (Van Cleemput and Samater, 1996). These processes are assumed to be of importance under acidic conditions, where microbial activity is limited. Since the kinetics of NO release follow a first order reaction, the net release of NO, which is usually measured in laboratory incubation experiments, can be separated into production and consumption terms. However, it should be emphasised that this concept has been shown to be valid only, if (i) production and consumption processes occur simultaneously, and (ii) are homogeneously distributed in the top soil layer (Rudolph et al., 1996; Rudolph and Conrad, 1996). Simultaneous occurrence of production and consumption processes imply the so-called compensation point; the mixing ratio, where production equals consumption and consequently the net NO release is zero, is defined as the NO compensation point mixing ratio (Conrad, 1994).

The major environmental factors that control the release of NO from soil are (i) soil moisture, (ii) soil temperature, (iii) the atmospheric mixing ratio of NO, and (iv) nitrogen availability/fertiliser application (Ludwig et al., 2001). In addition to these factors, several other controlling factors have been recognised. Gödde and Conrad (2000) investigated net NO release rates for a series of different soils under constant soil moisture and soil temperature. They identified soil nitrate and nitrite $\left(\mathrm{NO}_{3}^{-}, \mathrm{NO}_{2}^{-}\right)$, soil $\mathrm{pH}$, soil texture, and soil nitrification rates as further influencing factors for NO production, while microbial respiration, soil texture, and soil ammonium $\left(\mathrm{NH}_{4}^{+}\right)$have affected the consumption of NO. Stark et al. (2002) found in an earlier study that soils characterised by high organic carbon and $\mathrm{C}: \mathrm{N}$ ratio showed lower biogenic $\mathrm{NO}$ emissions. This might be explained by the fact that high availability of $\mathrm{C}$ leads to a greater demand for $\mathrm{N}$ and thereby to an increase of consumption of NO. If this is the case, soil organic carbon and microbial respiration might be used to predict the consumption or even the release of NO (Ashuri, 2009; Dunfield and Knowles, 1998; Stark et al., 2002; Gödde and Conrad, 2000).

Steinkamp and Lawrence (2011; Supplement) provide a recent compilation of numerous (110 studies in the last 3 decades) field measurements of NO fluxes. However, the majority of the studies concentrated on fertilised agricultural soils, despite the fact that $47 \%$ of the earth's surface is covered by drylands (UNEP, 1997) for which only a relatively small number of studies exists (Feig, 2009). Several field and laboratory methods have been established to study soil NO fluxes (in mass per area and time) as well as soil NO release rates (in mass per mass of dry soil and time) and their 
influencing factors, namely soil temperature, soil moisture, ambient NO mixing ratio, and more (Galbally and Johansson, 1989; Yang and Meixner, 1997; Pape et al., 2009; Gut et al., 1998; Wang et al., 2011; Gödde and Conrad, 1998). The most relevant parameter which has been determined either in field experiments (Slemr and Seiler, 1991) or during laboratory incubations is the NO compensation point mixing ratio, $m_{\mathrm{NO}}$,comp (Feig et al., 2008a, b; Bargsten et al., 2010; Remde et al., 1989). The NO production rate $\left(P_{\mathrm{NO}}\right)$, and the NO consumption rate coefficient $\left(k_{\mathrm{NO}}\right)$ need to be parameterised for the influencing factors separately, as they define $m_{\mathrm{NO}}$,comp, which in turn is needed to calculate the socalled net potential NO flux using soil-diffusion algorithms described by Galbally and Johansson (1989) and Meixner and Yang (2006). Once, the net potential NO flux is parameterised for soil moisture and soil temperature, routine measured field data of soil temperature and soil moisture have been used to up-scale the laboratory-derived net potential NO flux to different spatial (plot, ecosystem, region) and temporal scales. Up-scaled NO fluxes have been repeatedly shown to be in largely good agreement with those measured in the field (Mayer et al., 2011; Laville et al., 2009; van Dijk et al., 2002, Ludwig et al., 2001; Remde et al., 1993).

Laboratory incubation systems for the investigation of NO release from soil are usually dynamic chamber systems. Here, the net release rate of $\mathrm{NO}\left(J_{\mathrm{NO}}\right)$ from an enclosed soil sample is determined from the NO concentration difference between incoming and outgoing air. All further quantities, which are necessary to characterise NO production and NO consumption (i.e. $P_{\mathrm{NO}}, k_{\mathrm{NO}}, m_{\mathrm{NO}, \text { comp }}, Q_{10}$ values $J_{\mathrm{NO}}$ ) were usually derived from $J_{\mathrm{NO}}$ data, eventually obtained under different, mostly discrete soil temperature and soil moisture conditions. Particularly, the study of arid/hyper-arid as well as organic-rich soils by laboratory dynamic chambers has manifested obvious and partly substantial difficulties for the determination of $k_{\mathrm{NO}}, m_{\mathrm{NO}, \text { comp }}$, or corresponding $Q_{10}$ values (cf. Feig, 2009; Gelfand et al., 2009; Yu et al., 2008, 2010; Bargsten et al., 2010; Laville et al., 2009). Since there was reasonable suspicion that these difficulties are due to non-standardised pre-incubation protocols and sub-sample variability, it was decided to design an improved laboratory dynamic chamber system such that these difficulties will be eliminated. In the next section, the methodical concept for the determination of $J_{\mathrm{NO}}, P_{\mathrm{NO}}, k_{\mathrm{NO}}, m_{\mathrm{NO}}$,comp, and corresponding $Q_{10}$ values from only four pairs of NO mixing ratio is described in detail as well as the reasons to develop the improved laboratory dynamic chamber system. Furthermore, design of the improved system included the option to apply the system also for soil release studies of other trace gases. First attempts to determine (simultaneously with net NO release) the net release of $\mathrm{CO}_{2}$, and two volatile organic compounds (VOCs), namely acetone $\left(\mathrm{C}_{2} \mathrm{H}_{4} \mathrm{O}\right)$ and acetaldehyde $\left(\mathrm{C}_{3} \mathrm{H}_{6} \mathrm{O}\right)$ are also reported.

\section{The need for an improved laboratory dynamic chamber system: methodical concept vs. experimental reality}

\subsection{Methodical concept}

The dynamic chamber technique is applied to determine the release of a trace gas from the enclosed soil sample. The mass balance of the dynamic chamber necessitates that all mass fluxes into and out of the chamber's volume sum up to zero (see Sect. S1 of the Supplement). The mass flux $\Phi_{\text {in }}$ entering the chamber (in mass per time; here: $\mathrm{ng} \mathrm{s}^{-1}$ ) is equal to $Q \cdot c_{\text {in }}$, where $Q$ is the purging flow $\left(\mathrm{m}^{3} \mathrm{~s}^{-1}\right)$ and $c_{\text {in }}$ is the trace gas' concentration at the chamber's inlet $\left(\mathrm{ng} \mathrm{m}^{-3}\right)$. Given a wellmixed volume of the chamber, the concentration within the chamber $\left(c_{\text {cham }}\right)$ is identical to that at its outlet; consequently, the mass flux $\Phi_{\text {out }}$ leaving the chamber is equal to $Q \cdot c_{\text {cham }}$. The mass flux of the trace gas out of (or into) the soil $\left(\Phi_{\text {soil }}\right)$ is usually related to the mass of the soil sample $m_{\text {soil }}(\mathrm{kg})$ and is named the release rate $J$ (in $\operatorname{ng~kg}^{-1} \mathrm{~s}^{-1}$ ). Conventionally, fluxes into the chamber's volume are counted positive, those out of it negative; therefore, the chamber's mass balance equation delivers

$$
\begin{aligned}
J=\frac{\Phi_{\text {soil }}}{m_{\text {soil }}} & =\frac{Q c_{\text {cham }}-Q c_{\text {in }}}{m_{\text {soil }}} \\
& =\frac{Q}{m_{\text {soil }}}\left(m_{\text {cham }}-m_{\text {in }}\right) f_{\mathrm{C}, \mathrm{NO}},
\end{aligned}
$$

where $f_{\mathrm{C}, \mathrm{NO}}$ is the factor to convert the incoming and chamber NO mixing ratios ( $m_{\text {in }}$ and $m_{\text {cham }}, \mathrm{ppb}$ ) into corresponding NO concentrations $\left(f_{\mathrm{C}, \mathrm{NO}}=572.5 \mathrm{ng} \mathrm{m}^{-3} \mathrm{ppb}^{-1}\right.$, at $1013.25 \mathrm{hPa}$ and $T=25^{\circ} \mathrm{C}$; see Sect. 3.4).

If the release of the trace gas is the result of microbial production and consumption processes in the soil sample, the release rate $J$ is always a net release rate, which is defined by

$J=P-U$,

where $P$ and $U\left(\mathrm{ng} \mathrm{kg}^{-1} \mathrm{~s}^{-1}\right)$ are the rates of trace gas production and consumption, respectively. If $P>U$, the net release rate $J$ is positive, if $U>P$, then $J$ becomes negative. According to Eq. (1) this is equivalent to $m_{\text {cham }}>m_{\text {in }}$ and $m_{\text {cham }}<m_{\text {in }}$, respectively. For $U=P, J$ equals zero and the corresponding mixing ratio in the chamber's headspace is called the compensation point mixing ratio $m_{\mathrm{NO} \text {, comp }}$ (because here, the consumption of the trace gas in the soil sample compensates its production).

Since Remde et al. (1989), it has frequently been shown experimentally that there is a strong linear relationship between $J_{\mathrm{NO}}$ and the chamber's $\mathrm{NO}$ mixing ratio $m_{\mathrm{NO} \text {, cham }}$ :

$J_{\mathrm{NO}}\left(m_{\mathrm{NO}, \text { cham }}\right)=P_{\mathrm{NO}}+k_{\mathrm{NO}} m_{\mathrm{NO}, \text { cham }} f_{\mathrm{C}, \mathrm{NO}}$,

where $k_{\mathrm{NO}}$ is the so-called NO consumption rate coefficient (in $\mathrm{m}^{3} \mathrm{~kg}^{-1} \mathrm{~s}^{-1}$, which is counted negative). This 


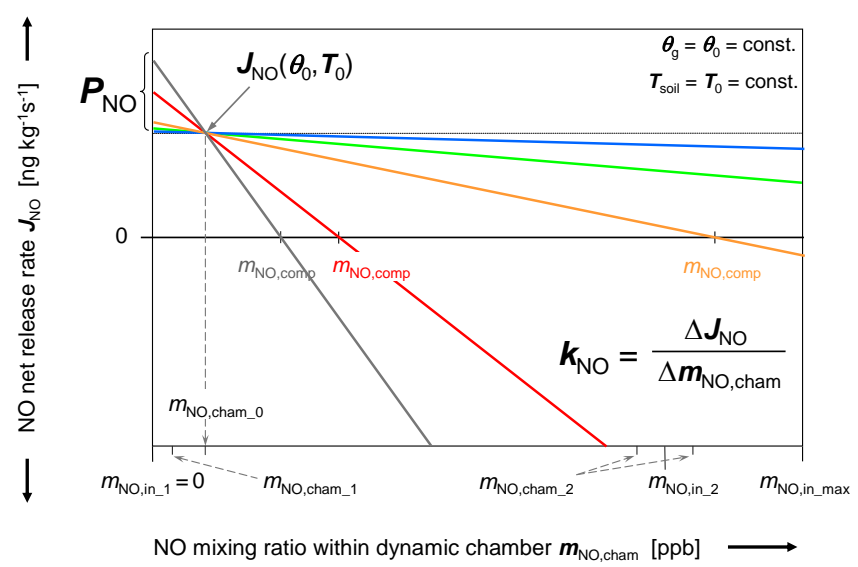

Figure 1. Schematic of NO net release rate $J_{\mathrm{NO}}$ vs. NO mixing ratio $m_{\mathrm{NO} \text {,cham }}$ in the headspace of the dynamic chamber at constant soil temperature and soil moisture; different indices on $\mathrm{NO}$ mixing ratios at the inlet $\left(m_{\mathrm{NO}, \text { in }}\right)$ or within the dynamic chamber $\left(m_{\mathrm{NO}}\right.$,cham $)$ are explained in the text (note: $m_{\mathrm{NO}, \text { cham } \_2}<m_{\mathrm{NO}, \text { in_2 }}$, if $m_{\mathrm{NO} \text {, cham } \_2}>m_{\mathrm{NO}, \text { comp }}$, and $m_{\mathrm{NO}, \text { cham } \_2}>m_{\mathrm{NO}, \text { in } \_2}$, if $\left.m_{\mathrm{NO}, \text { cham } \_2}<m_{\mathrm{NO}, \text { comp }}\right)$.

relation is linear for a wide range of $m_{\mathrm{NO} \text {,cham, and is }}$ schematically shown in Fig. 1. The relation implies that $P_{\mathrm{NO}}$ is independent of $m_{\mathrm{NO}}$,cham, while the NO consumption rate $\left(U_{\mathrm{NO}}\right)$ is dependent on $m_{\mathrm{NO} \text {, cham }}$ and can be described by a first order decay process, characterised by the consumption rate coefficient $k_{\mathrm{NO}}$. The compensation point mixing ratio, defined by $J_{\mathrm{NO}}\left(m_{\mathrm{NO} \text {, cham }}\right)=0$, is just $m_{\mathrm{NO}, \mathrm{comp}}=-P_{\mathrm{NO}} /\left(k_{\mathrm{NO}} f_{\mathrm{C}, \mathrm{NO}}\right)$. Considering Eqs. (1) and (3), the determination (and further characterisation) of $P_{\mathrm{NO}}$ and $U_{\mathrm{NO}}\left(k_{\mathrm{NO}}\right)$ can be basically achieved by measurements of only two related NO mixing ratio sets, namely $\left(m_{\mathrm{NO}, \text { in } \_1} ; m_{\mathrm{NO} \text {, cham } \_1}\right)$ and $\left(m_{\mathrm{NO}, \text { in } \_2} ; m_{\mathrm{NO}, \text { cham } \_2}\right)$, where $m_{\mathrm{NO}, \text { cham } \_2}>m_{\mathrm{NO}, \text { cham_1 }}\left(\right.$ and $\left.m_{\mathrm{NO}, \text { in_2 }}>m_{\mathrm{NO} \text {,in_1 } 1}\right)$.

However, the NO net release rate has been observed to be also strongly dependent on the temperature of the soil $\left(T_{\text {soil }}\right)$, as well as the moisture content $\theta_{\mathrm{g}}$ (i.e. dimensionless gravimetric soil moisture, see Sect. S1 of the Supplement) of the soil sample (e.g. Ludwig et al., 2001). Therefore, $J_{\mathrm{NO}}$ is defined to be dependent on a total of three variables, namely $\theta_{\mathrm{g}}$, $T_{\text {soil }}$, and $m_{\mathrm{NO}, \text { cham }}$

$$
\begin{aligned}
J_{\mathrm{NO}}\left(\theta_{\mathrm{g}}, T_{\text {soil }}, m_{\mathrm{NO}, \text { cham }}\right) & =P_{\mathrm{NO}}\left(\theta_{\mathrm{g}}, T_{\text {soil }}\right) \\
& -U_{\mathrm{NO}}\left(\theta_{\mathrm{g}}, T_{\text {soil }}, m_{\mathrm{NO}, \text { cham }}\right),
\end{aligned}
$$

considering Eq. (3), this is equivalent to

$$
\begin{aligned}
J_{\mathrm{NO}}\left(\theta_{\mathrm{g}}, T_{\text {soil }}, m_{\mathrm{NO}, \text { cham }}\right) & =P_{\mathrm{NO}}\left(\theta_{\mathrm{g}}, T_{\text {soil }}\right) \\
& +k_{\mathrm{NO}}\left(\theta_{\mathrm{g}}, T_{\text {soil }}\right) m_{\mathrm{NO}, \text { cham }} f_{\mathrm{C}, \mathrm{NO}} .
\end{aligned}
$$

Since NO production and NO consumption in the soil are enzymatic processes (e.g. Schuster and Conrad; 1992), an exponential dependence on soil temperature can generally be

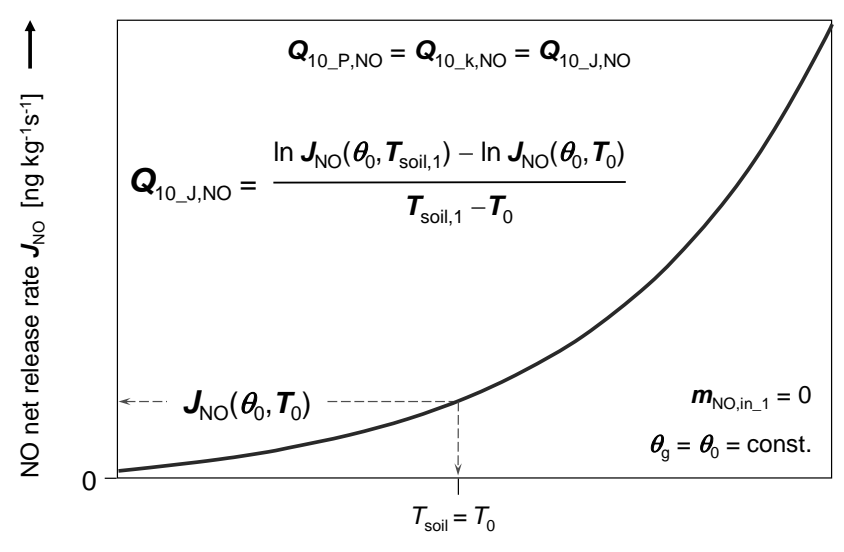

soil temperature $\boldsymbol{T}_{\text {soil }}\left[{ }^{\circ} \mathrm{C}\right]$

Figure 2. Schematic of NO net release rate $J_{\mathrm{NO}} v s$. temperature $T_{\text {soil }}$ of the enclosed soil sample at constant gravimetric soil moisture and "zero"-air at the dynamic chamber's inlet (note: the shown exponential dependence for $J_{\mathrm{NO}}\left(T_{\text {soil }}\right)$ is only valid, if $Q_{10}$ values of both, NO production $\left(Q_{10} \mathrm{P}, \mathrm{NO}\right)$ and NO consumption $\left(Q_{10 \_\mathrm{k}, \mathrm{NO}}\right)$ are identical; in this case $Q_{10 \_\mathrm{J}, \mathrm{NO}}$ equals $Q_{10 \_\mathrm{P}, \mathrm{NO}}=$

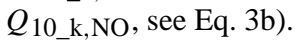

assumed (see Fig. 2). Hence, for a constant (fixed) gravimetric soil moisture $\left(\theta_{\mathrm{g}}=\theta_{0}\right), P_{\mathrm{NO}}$ and $U_{\mathrm{NO}}$ are described by

$$
\begin{aligned}
P_{\mathrm{NO}}\left(\theta_{0}, T_{\text {soil }}\right) & =n P_{\mathrm{NO}}\left(\theta_{0}, T_{0}\right) \exp \left(\frac{\ln Q_{10 \_\mathrm{P}, \mathrm{NO}}}{10}\left(T_{\text {soil }}-T_{0}\right)\right) \\
& =P_{\mathrm{NO}}\left(\theta_{0}, T_{0}\right) Q_{10 \_\mathrm{P}, \mathrm{NO}}^{\left(T_{\text {soil }}-T_{0}\right) / 10} \\
U_{\mathrm{NO}}\left(\theta_{0}, T_{\text {soil }}\right) & =U_{\mathrm{NO}}\left(\theta_{0}, T_{0}\right) \exp \left(\frac{\ln Q_{10 \_\mathrm{U}, \mathrm{NO}}}{10}\left(T_{\text {soil }}-T_{0}\right)\right) \\
& =U_{\mathrm{NO}}\left(\theta_{0}, T_{0}\right) Q_{10 \_\mathrm{U}, \mathrm{NO}}^{\left(T_{\text {soil }}-T_{0}\right) / 10}
\end{aligned}
$$

where $T_{0}$ is a certain reference soil temperature (i.e. where $P_{\mathrm{NO}}\left(\theta_{0}, T_{\text {soil }}\right)=P_{\mathrm{NO}}\left(\theta_{0}, T_{0}\right)$ and $U_{\mathrm{NO}}\left(\theta_{0}, T_{\text {soil }}\right)=U_{\mathrm{NO}}\left(\theta_{0}\right.$, $\left.\left.T_{0}\right)\right)$. $Q_{10 \_\mathrm{P}, \mathrm{NO}}$ and $Q_{10 \_\mathrm{U}, \mathrm{NO}}$ are defined by individual ratios of $P_{\mathrm{NO}}$ and $U_{\mathrm{NO}}$ at two different temperatures which differ by ten degrees (i.e. without loss of generality, $T_{0}$ and $T_{1}=$ $\left.T_{0}+10\right)$ :

$$
\begin{aligned}
& Q_{10 \_ \text {P,NO }}=\frac{P_{\mathrm{NO}}\left(\theta_{0}, T_{1}\right)}{P_{\mathrm{NO}}\left(\theta_{0}, T_{0}\right)}=\frac{P_{\mathrm{NO}}\left(\theta_{0}, T_{0}+10\right)}{P_{\mathrm{NO}}\left(\theta_{0}, T_{0}\right)} \\
& Q_{10 \_ \text {U,NO }}=\frac{U_{\mathrm{NO}}\left(\theta_{0}, T_{1}\right)}{U_{\mathrm{NO}}\left(\theta_{0}, T_{0}\right)}=\frac{U_{\mathrm{NO}}\left(\theta_{0}, T_{0}+10\right)}{U_{\mathrm{NO}}\left(\theta_{0}, T_{0}\right)} .
\end{aligned}
$$

From Eqs. (7), (2a), and (3a) it is evident that $Q_{10 \_\mathrm{U}, \mathrm{NO}}=$ $Q_{10 \_ \text {k,NO}}$. Combining Eqs. (2a), (4), and (5) leads to

$$
\begin{gathered}
J_{\mathrm{NO}}\left(\theta_{0}, T_{0}, m_{\mathrm{NO}, \text { cham }}\right)=P\left(\theta_{0}, T_{0}\right) Q_{10 \_\mathrm{P}, \mathrm{NO}}^{\left(T_{\text {soil }}-T_{0}\right) / 10} \\
+k\left(\theta_{0}, T_{0}\right) Q_{10 \_\mathrm{k}, \mathrm{NO}}^{\left(T_{\text {soil }}-T_{0}\right) / 10} m_{\mathrm{NO}, \text { cham }} f_{\mathrm{C}, \mathrm{NO}} .
\end{gathered}
$$

The relationships between $P_{\mathrm{NO}}$ as well as $U_{\mathrm{NO}}$ and the soil temperature are log-linear. Consequently, measurements at 
least at two different soil temperatures are necessary to characterise their temperature dependency. Since the determination of $P_{\mathrm{NO}}$ and $k_{\mathrm{NO}}$ for any soil temperature needs already at least two measurements at two different $\mathrm{NO}$ mixing ratio levels, the determination of $Q_{10 \_ \text {P,NO }}$ and $Q_{10 \_ \text {k,NO needs }}$ finally at least four measurements of related NO mixing ratio data sets, namely $\left(m_{\mathrm{NO}, \text { in } \_1} ; m_{\mathrm{NO}, \text { cham } \_1}\right)$ and $\left(m_{\mathrm{NO}, \text { in } \_} ;\right.$; $\left.m_{\mathrm{NO}, \text { cham } \_2}\right)$ at $T=T_{0}$ and $\left(m_{\mathrm{NO}, \text { in } \_3} ; m_{\mathrm{NO}, \text { cham } \_3}\right)$ and $\left(m_{\mathrm{NO}, \text { in_4 } 4} ; m_{\mathrm{NO}, \text { cham_4 }}\right)$ at $T_{1}=T_{0}+10$.

During the last two decades, it has repeatedly been shown that $J_{\mathrm{NO}}$ follows the soil moisture $\theta_{\mathrm{g}}$ in form of an optimum curve (Yang and Meixner, 1997; Otter et al., 1999; Kirkman et al., 2001; van Djik and Meixner, 2001; van Dijk et al., 2002; Garrido et al., 2002; Meixner and Yang, 2006; Yu et al., 2008, 2010; Feig et al., 2008a, b; Ashuri, 2009; Feig, 2009; Laville et al., 2009; Gelfand et al., 2009; Bargsten et al., 2010). This is schematically shown in Fig. 3.

As mentioned above, the optimum curve relationship between $J_{\mathrm{NO}}$ and $\theta_{\mathrm{g}}$ is in accordance with the general behaviour of soil microbial activity in aerobic soils (Skopp et al., 1990). Hence, it is supposed that both processes, NO production as well as NO consumption, follow jointly the optimum curve with $\theta_{\mathrm{g}}$. Consequently, their optimum (maximum) values, namely $P_{\mathrm{NO} \text {,opt }}$ and $U_{\mathrm{NO} \text {, opt }}$ (consequently also $k_{\mathrm{NO} \text {,opt }}$ ), occur at the same optimum gravimetric soil moisture $\theta_{\mathrm{g}, \mathrm{opt}}$, which henceforth is denoted as $\theta_{0}$. The form of the optimum curve can be generally described by the product of a (increasing) power function and a (decreasing) exponential function (e.g. Bronstein and Semendajew, 1972). For $T_{\text {soil }}=T_{0}$ and $m_{\text {in_1 } 1}=0$, the corresponding NO net release' optimum curve $J_{\mathrm{NO}}\left(\theta_{\mathrm{g}}, T_{0}\right)$ can be described as follows (cf. Meixner and Yang, 2008):

$J_{\mathrm{NO}}\left(\theta_{\mathrm{g}}, T_{0}\right)=J\left(\theta_{0}, T_{0}\right)\left(\frac{\theta_{\mathrm{g}}}{\theta_{0}}\right)^{a} \exp \left[-a\left(\frac{\theta_{\mathrm{g}}}{\theta_{0}}-1\right)\right]$,

where $J_{\mathrm{NO}}\left(\theta_{\mathrm{g}}, \mathrm{T}_{0}\right)$ is determined via Eq. (1) from a preset $m_{\text {in_1 } 1}$ (preferably $m_{\text {in_1 } 1}=0$; without loss of generality) and the chamber's NO mixing ratio measured at $\theta_{\mathrm{g}}=\theta_{0}$ (henceforth denoted as $m_{\mathrm{NO} \text {,cham } \_1,0}$ ). The optimum curve's shapecoefficient $a$ is then given by

$a=\ln \frac{J_{\mathrm{NO}}\left(\theta_{0}, T_{0}\right)}{J_{\mathrm{NO}}\left(\theta_{\mathrm{g}, 1}, T_{0}\right)}\left[\ln \frac{\theta_{0}}{\theta_{\mathrm{g}, 1}}+\frac{\theta_{\mathrm{g}, 1}}{\theta_{0}}-1\right]^{-1}$.

The value of $\theta_{\mathrm{g}, 1}$ can arbitrarily be chosen, e.g. such that

$\frac{J_{\mathrm{NO}}\left(\theta_{0}, T_{0}\right)}{J_{\mathrm{NO}}\left(\theta_{\mathrm{g}, 1}, T_{0}\right)}=R_{J}$

Hence, Eq. (8a) will read as

$a=\frac{\ln R_{J}}{\ln \frac{\theta_{0}}{\theta_{\mathrm{g}, 1}}+\frac{\theta_{\mathrm{g}, 1}}{\theta_{0}}-1}$.

It is compulsory from Eq. (8) - (8c) that only two data pairs are necessary to define the shape of the optimum curve,

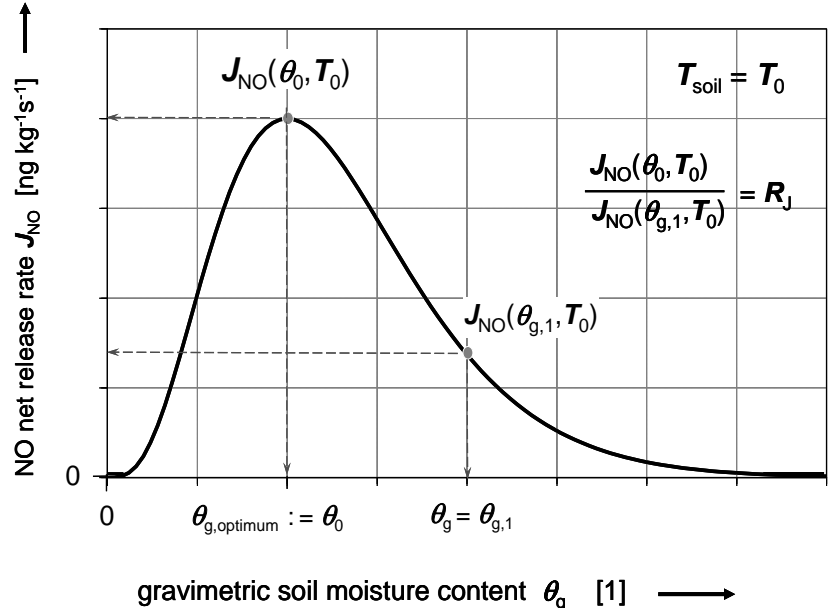

Figure 3. Schematic of $\mathrm{NO}$ net release rate $J_{\mathrm{NO}}$ vs. gravimetric soil moisture $\theta_{\mathrm{g}}$ at constant soil temperature. The ratio $J_{\mathrm{NO}}\left(\theta_{0}\right) / J_{\mathrm{NO}}\left(\theta_{\mathrm{g}, 1}\right)=R_{J}$ is chosen arbitrarily (without loss of generality).

namely (i) the optimum (maximum) value of the NO net release rate and the related (optimum) gravimetric soil moisture (i.e. $J_{\mathrm{NO}}\left(\theta_{0}, T_{0}\right)$ and $\left.\theta_{0}\right)$, and (ii) the value of that gravimetric soil moisture where the NO net release is $1 / R_{J}$ of the maximum value of the NO net release rate (i.e. $\theta_{\mathrm{g}, 1}$ at $\left.J_{\mathrm{NO}}\left(\theta_{\mathrm{g}, 1}, T_{0}\right)=J_{\mathrm{NO}}\left(\theta_{0}, T_{0}\right) / R_{J}\right)$. For practical reasons $\theta_{\mathrm{g}, 1}$ should be selected such that $\theta_{\mathrm{g}, 1}>\theta_{0}$.

Fortunately, $T_{\text {soil }}=T_{0}$ and $m_{\text {in_1 }}=0$ can easily be obtained: (i) the soil temperature can be kept constant by enclosing the dynamic chamber in a thermostat, and (ii) $m_{\text {in } 1}=0$ is achieved by purging the dynamic chamber with NO-free, so-called "zero" air (see Sect. 3.2.1). The necessary variation of the gravimetric soil moisture over its full range is realised by (i) wetting the soil sample (e.g. to its water holding capacity, see Sect. 3.1) at the start of the experiment and (ii) purging the dynamic chamber continuously by air (of any NO mixing ratio) with a dew point (much) less than $T_{\text {soil }}$. The enforced evaporation of water vapour from the soil sample results in a continuous drying out of the soil sample and consequently provides the desired variation of the gravimetric soil moisture over its full range.

This drying out experiment delivers the necessary data to calculate the optimum curve's shape coefficient $a$ (i.e. $\theta_{0}$ and $\theta_{\mathrm{g}, 1}$; cf. Eq. 8c). Then the gravimetric soil moisture's shapefunction $g\left(\theta_{\mathrm{g}}\right)$ is defined as

$g\left(\theta_{\mathrm{g}}\right)=\left(\frac{\theta_{\mathrm{g}}}{\theta_{0}}\right)^{a} \exp \left[-a\left(\frac{\theta_{\mathrm{g}}}{\theta_{0}}-1\right)\right]$.

Note that $g\left(\theta_{\mathrm{g}}\right)=1$ for $\theta_{g}=\theta_{0}$. Considering Eq. (8), the dependency of $J_{\mathrm{NO}}\left(\theta_{\mathrm{g}}, T_{\mathrm{soil}}, m_{\mathrm{NO} \text {, cham }}\right), P_{\mathrm{NO}}\left(\theta_{\mathrm{g}}, T_{\text {soil }}\right)$, and $U_{\mathrm{NO}}\left(\theta_{\mathrm{g}}, T_{\mathrm{soil}}, m_{\mathrm{NO}, \text { cham }}\right)$ from gravimetric soil moisture becomes

$$
J_{\mathrm{NO}}\left(\theta_{\mathrm{g}}, T_{\mathrm{soil}}, m_{\mathrm{NO}, \text { cham }}\right)=J_{\mathrm{NO}}\left(\theta_{0}, T_{\text {soil }}, m_{\mathrm{NO}, \text { cham }}\right) g\left(\theta_{\mathrm{g}}\right)
$$


$P_{\mathrm{NO}}\left(\theta_{\mathrm{g}}, T_{\text {soil }}\right)=P_{\mathrm{NO}}\left(\theta_{0}, T_{\text {soil }}\right) g\left(\theta_{\mathrm{g}}\right)$

$$
\begin{gathered}
U_{\mathrm{NO}}\left(\theta_{\mathrm{g}}, T_{\mathrm{soil}}, m_{\mathrm{NO}, \text { cham }}\right)=U_{\mathrm{NO}}\left(\theta_{0}, T_{\mathrm{soil}}, m_{\mathrm{NO}, \text { cham }}\right) g\left(\theta_{\mathrm{g}}\right) \\
\quad=k_{\mathrm{NO}}\left(\theta_{0}, T_{\text {soil }}\right) m_{\mathrm{NO}, \text { cham }} f_{\mathrm{C}, \mathrm{NO}} g\left(\theta_{\mathrm{g}}\right),
\end{gathered}
$$

because NO production and NO consumption (consequently also the NO net release) share the same shape of the soil moisture's optimum curve. Combining Eqs. (3a), (3b), and (10.1)-(10.3) leads to the desired general formulation of the NO net release rate (Eq. 2a) as function of $\theta_{\mathrm{g}}, T_{\text {soil }}$, and $m_{\mathrm{NO}, \text { cham }}$

$$
\begin{aligned}
& J_{\mathrm{NO}}\left(\theta_{\mathrm{g}}, T_{\text {soil }}, c_{\mathrm{NO}, \text { cham }}\right)=\left[P\left(\theta_{0}, T_{0}\right) Q_{10 \_\mathrm{P}, \mathrm{NO}}^{\left(T_{\text {soil }}-T_{0}\right) / 10}\right. \\
& \left.\quad+k\left(\theta_{0}, T_{0}\right) Q_{10 \_\mathrm{k}, \mathrm{NO}}^{\left(T_{\text {soil }}-T_{0}\right) / 10} m_{\mathrm{NO}, \text { cham }} f_{\mathrm{C}, \mathrm{NO}}\right] g\left(\theta_{\mathrm{g}}\right) .
\end{aligned}
$$

There are six parameters in Eq. (11) which have to be determined by suitable experiments: $\theta_{0}$ and $a$ (defining $g\left(\theta_{\mathrm{g}}\right)$ ), as well as $P_{\mathrm{NO}}\left(\theta_{0}, T_{0}\right), k_{\mathrm{NO}}\left(\theta_{0}, T_{0}\right), Q_{10 \_\mathrm{P}, \mathrm{NO}}$, and $Q_{10 \_\mathrm{k}, \mathrm{NO}}$. Given that $T_{\text {soil }}$ and $\theta_{\mathrm{g}}$ are known (by direct or indirect measurements, see Sect. 3.4), the quantities which have to be measured during a dynamic chamber experiment are only the NO mixing ratios at the inlet and within the chamber. As already mentioned above, at least four different experiments are necessary over the full range of gravimetric soil moisture $\theta_{\mathrm{g}}:$

$$
\begin{aligned}
& \text { exp. 1: at } T_{\text {soil }}=T_{0} \text { and } m_{\mathrm{NO}, \text { in }}=m_{\mathrm{NO}, \text { in_1 }} \\
& \text { exp. 2: at } T_{\text {soil }}=T_{0} \text { and } m_{\mathrm{NO}, \text { in }}=m_{\mathrm{NO}, \text { in_2 }} \\
& \text { exp. 3: at } T_{\text {soil }}=T_{1} \text { and } m_{\mathrm{NO}, \text { in }}=m_{\mathrm{NO}, \text { in_3 }} \\
& \text { exp. 4: at } T_{\text {soil }}=T_{1} \text { and } m_{\mathrm{NO}, \text { in }}=m_{\mathrm{NO}, \text { in_4 }} .
\end{aligned}
$$

At first, experiment (1) delivers the necessary data $\left(\theta_{0}, \theta_{\mathrm{g}, 1}\right)$ for the determination of the optimum curve's shape function $g\left(\theta_{\mathrm{g}}\right)$. Assuming that the respective optimum (maxi$\mathrm{mal} / \mathrm{minimal}$ ) values of $J_{\mathrm{NO}}$ in all four experiments will be observed at the same optimum gravimetric soil moisture $\theta_{0}$ (which could be proofed for each drying-out experiment), the four experiments will provide four data pairs at optimum gravimetric soil moisture, the respective NO mixing ratio within the chamber and the corresponding NO release rate (which is determined by the respective difference of NO mixing ratio within and at the inlet of the chamber; cf. Eq. 1):

exp. 1: $m_{\mathrm{NO}, \text { cham_ } 1,0}$ and $J_{\mathrm{NO}}\left(\theta_{0}, T_{0}, m_{\mathrm{NO}, \text { cham } \_1,0}\right)$ $=Q / m_{\mathrm{soil}}\left(m_{\mathrm{NO}, \text { cham_ } \_1,0}-m_{\mathrm{NO}, \text { in_1 } 1}\right) f_{\mathrm{C}, \mathrm{NO}}$

exp. 2: $m_{\mathrm{NO}, \text { cham } \_2,0}$ and $J_{\mathrm{NO}}\left(\theta_{0}, T_{0}, m_{\mathrm{NO}, \text { cham } \_2,0}\right)$ $=Q / m_{\text {soil }}\left(m_{\mathrm{NO}, \text { cham } \_2,0}-m_{\mathrm{NO}, \text { in } \_2}\right) f_{\mathrm{C}, \mathrm{NO}}$

exp. 3: $m_{\mathrm{NO}, \text { cham } \_3,0}$ and $J_{\mathrm{NO}}\left(\theta_{0}, T_{1}, m_{\mathrm{NO}, \text { cham } \_3,0}\right)$ $=Q / m_{\text {soil }}\left(m_{\mathrm{NO}, \text { cham } \_3,0}-m_{\mathrm{NO}, \text { in_3 }}\right) f_{\mathrm{C}, \mathrm{NO}}$ exp. 4: $m_{\mathrm{NO}, \text { cham } \_4,0}$ and $J_{\mathrm{NO}}\left(\theta_{0}, T_{1}, m_{\mathrm{NO}, \text { cham } \_4,0}\right)$ $=Q / m_{\text {soil }}\left(m_{\mathrm{NO}, \text { cham_4,0 }}-m_{\mathrm{NO}, \text { in_4 }}\right) f_{\mathrm{C}, \mathrm{NO}}$.

For experiments (1) and (2), $T_{\text {soil }}$ equals $T_{0}$, consequently

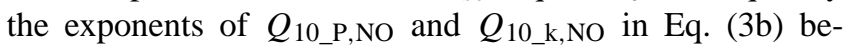
come zero. Then, the reference NO consumption coefficient $k_{\mathrm{NO}}\left(\theta_{0}, T_{0}\right)$, the slope of the linear relation between $J_{\mathrm{NO}}$, and $m_{\mathrm{NO} \text {, cham }}$, is determined by

$k_{\mathrm{NO}}\left(\theta_{0}, T_{0}\right)$

$=\frac{J_{\mathrm{NO}}\left(\theta_{0}, T_{0}, m_{\mathrm{NO}, \text { cham } \_2,0}\right)-J_{\mathrm{NO}}\left(\theta_{0}, T_{0}, m_{\mathrm{NO}, \text { cham } \_1,0}\right)}{\left(m_{\mathrm{NO}, \text { cham } \_2,0}-m_{\mathrm{NO}, \text { cham } \_1,0}\right) f_{\mathrm{C}, \mathrm{NO}}}$,

which is equivalent to

$k_{\mathrm{NO}}\left(\theta_{0}, T_{0}\right)$

$=\frac{Q}{m_{\text {soil }}} \frac{\left(m_{\mathrm{NO}, \text { cham } \_2,0}-m_{\mathrm{NO}, \mathrm{in} \_2}\right)-\left(m_{\mathrm{NO}, \text { cham } \_1,0}-m_{\mathrm{NO}, \mathrm{in} \_1}\right)}{m_{\mathrm{NO}, \text { cham } \_2,0}-m_{\mathrm{NO}, \text { cham } \_1,0}}$.

Hence, it follows for $P_{\mathrm{NO}}\left(\theta_{0}, T_{0}\right)$,

$$
\begin{aligned}
P_{\mathrm{NO}}\left(\theta_{0}, T_{0}\right) & =J_{\mathrm{NO}}\left(\theta_{0}, T_{0}, m_{\mathrm{NO}, \text { cham } \_1,0}\right) \\
& -k_{\mathrm{NO}}\left(\theta_{0}, T_{0}\right) m_{\mathrm{NO}, \text { cham__ } 1,0} f_{\mathrm{C}, \mathrm{NO}},
\end{aligned}
$$

which is equivalent to

$P_{\mathrm{NO}}\left(\theta_{0}, T_{0}\right)=\frac{Q f_{\mathrm{C}, \mathrm{NO}}}{m_{\mathrm{soil}}}\left(m_{\mathrm{NO}, \text { cham }_{-} 1,0}-m_{\mathrm{NO}, \text { in }_{-} 1}\right)$

$-k_{\mathrm{NO}}\left(\theta_{0}, T_{0}\right) m_{\mathrm{NO}, \text { cham_ } 1,0} f_{\mathrm{C}, \mathrm{NO}}$.

Analogously from experiments (3) and (4):

$$
\begin{aligned}
& k_{\mathrm{NO}}\left(\theta_{0}, T_{1}\right) \\
& =\frac{Q}{m_{\text {soil }}} \frac{\left(m_{\mathrm{NO}, \text { cham } \_4,0}-m_{\mathrm{NO}, \text { in } \_4}\right)-\left(m_{\mathrm{NO}, \text { cham } \_3,0}-m_{\mathrm{NO}, \mathrm{in} \_3}\right)}{m_{\mathrm{NO}, \text { cham } \_4,0}-m_{\mathrm{NO}, \text { cham } \_3,0}} \\
& P_{\mathrm{NO}}\left(\theta_{0}, T_{1}\right)=\frac{Q f_{\mathrm{C}, \mathrm{NO}}}{m_{\text {soil }}}\left(m_{\mathrm{NO}, \text { cham } \_3,0}-m_{\mathrm{NO}, \mathrm{in} \_3}\right) \\
& \quad-k_{\mathrm{NO}}\left(\theta_{0}, T_{0}\right) m_{\mathrm{NO}, \text { cham } \_3,0} f_{\mathrm{C}, \mathrm{NO} .} .
\end{aligned}
$$

The remaining parameters in Eq. (11) are $Q_{10 \_ \text {P,NO }}$ and $Q_{10 \_\mathrm{k}, \mathrm{NO}}$, which are defined by the ratio of $P_{\mathrm{NO}}\left(\theta_{0}\right.$, $\left.T_{1}\right) / P_{\mathrm{NO}}\left(\theta_{0}, T_{0}\right)$ and $k_{\mathrm{NO}}\left(\theta_{0}, T_{1}\right) / k_{\mathrm{NO}}\left(\theta_{0}, T_{1}\right)$, respectively (note: $\left.T_{1}=T_{0}+10\right)$. Combining Eqs. (12b) and (14b), as well as Eqs. (13b) and (15b), after some mathematical rearrangements, it follows that

$$
\begin{aligned}
Q_{10 \_\mathrm{k}, \mathrm{NO}}= & \frac{m_{\mathrm{NO}, \mathrm{cham} \_4,0}-m_{\mathrm{NO}, \mathrm{in} \_4}-m_{\mathrm{NO}, \mathrm{cham} \_3,0}+m_{\mathrm{NO}, \mathrm{in} \_3}}{m_{\mathrm{NO}, \mathrm{cham} \_2,0}-m_{\mathrm{NO}, \mathrm{in} \_2}-m_{\mathrm{NO}, \mathrm{cham} \_1,0}+m_{\mathrm{NO}, \mathrm{in} \_1}} \\
& \cdot \frac{m_{\mathrm{NO}, \mathrm{cham} \_2,0}-m_{\mathrm{NO}, \mathrm{cham} \_1,0}}{m_{\mathrm{NO}, \text { cham }} \_4,0-m_{\mathrm{NO}, \text { cham } \_3,0}}
\end{aligned}
$$

$$
Q_{10 \_\mathrm{P}, \mathrm{NO}}=\frac{m_{\mathrm{NO}, \text { cham } \_3,0}\left(1-\frac{m_{\text {soil }}}{Q} k\left(\theta_{0}, T_{1}\right)\right)-m_{\mathrm{NO}, \text { in } \_3}}{m_{\mathrm{NO}, \text { cham } \_1,0}\left(1-\frac{m_{\text {soil }}}{Q} k\left(\theta_{0}, T_{0}\right)\right)-m_{\mathrm{NO}, \text { in_ } \_}} .
$$


Using Eqs. (12b), (13b), (16), and (17), the six unknown parameters $\left(\theta_{0}, a, P_{\mathrm{NO}}\left(\theta_{0}, T_{0}\right), k_{\mathrm{NO}}\left(\theta_{0}, T_{0}\right), Q_{10 \_\mathrm{P}, \mathrm{NO}}\right.$, $\left.Q_{10 \mathrm{k}, \mathrm{NO}}\right)$ of the general formulation of the NO net release rate (Eq. 11) can be determined from direct and immediate measurements of $\mathrm{NO}$ mixing ratios only.

The expected variations of the NO net release rate which should be observed under different conditions of gravimetric soil moisture, soil temperature, and the chamber's headspace NO mixing ratio, are schematically shown in Fig. 4. Moreover, this figure summarises the methodical concept of the applied dynamic chamber approach.

It is worthwhile to note that the compensation point mixing ratio, defined by $m_{\mathrm{NO}}$, comp $=-P_{\mathrm{NO}} /\left(k_{\mathrm{NO}} f_{\mathrm{C}, \mathrm{NO}}\right)$, is not a function of $\theta_{\mathrm{g}}$, as long as NO production and NO consumption respond identically to variations of gravimetric soil moisture. Furthermore, if $Q_{10 \_\mathrm{P}, \mathrm{NO}}=Q_{10 \_\mathrm{k}, \mathrm{NO}}\left(=Q_{10 \_\mathrm{NO}}\right)$, the temperature dependence of both processes as well as that of $J_{\mathrm{NO}}$ can be described by

$h\left(T_{\text {soil }}\right)=J\left(\theta_{0}, T_{0}\right) Q_{10 \_ \text {NO }}^{\left(T_{\text {soil }}-T_{0}\right) / 10}$.

Consequently, the general formulation of NO net release, $\mathrm{NO}$ production, and NO consumption rates as function of $\theta_{\mathrm{g}}$, $T_{\text {soil }}$, and $m_{\mathrm{NO} \text {,cham }}$ would be reduced to

$$
\begin{aligned}
& P_{\mathrm{NO}}\left(\theta_{\mathrm{g}}, T_{\text {soil }}\right)=P_{\mathrm{NO}}\left(\theta_{0}, T_{0}\right) g\left(\theta_{\mathrm{g}}\right) h\left(T_{\text {soil }}\right) \\
& U_{\mathrm{NO}}\left(\theta_{\mathrm{g}}, T_{\text {soil }}, m_{\mathrm{NO}, \text { cham }}\right) \\
& \quad=U_{\mathrm{NO}}\left(\theta_{0}, T_{0}, m_{\mathrm{NO}, \text { cham }}\right) g\left(\theta_{\mathrm{g}}\right) h\left(T_{\text {soil }}\right) \\
& \quad=k_{\mathrm{NO}}\left(\theta_{0}, T_{0}\right) m_{\mathrm{NO}, \text { cham }} f_{\mathrm{C}, \mathrm{NO}} g\left(\theta_{\mathrm{g}}\right) h\left(T_{\text {soil }}\right) \\
& \left.\quad \quad+k\left(\theta_{0}, T_{0}\right) m_{\mathrm{NO}, \text { cham }} f_{\mathrm{C}, \mathrm{NO}}\right] g\left(\theta_{\mathrm{g}}\right) h\left(T_{\text {soil }}\right) .
\end{aligned}
$$

Consequently, the compensation point mixing ratio $m_{\mathrm{NO}}$,comp would then be neither a function of gravimetric soil moisture, nor of soil temperature: $m_{\mathrm{NO}}$,comp would get the significance of a "fixed" microbiological soil parameter.

\subsection{Experimental reality - need and challenges of an improved laboratory method}

For more than two decades (from Remde et al., 1989 until Bargsten et al., 2010), various experiments to determine the net NO release rate from soils have been performed on individual sub-samples out of the respective bulk soil sample from a given ecosystem. Generally, the bulk soil samples have been (i) passed through a screen (usually $2 \mathrm{~mm}$; $16 \mathrm{~mm}$ for forest soils of high organic content, cf. Bargsten et al., 2010) to remove large pieces of rock, roots, and litter, (ii) mechanically homogenised, and (iii) pre-incubated at prescribed soil moisture contents before the actual (drying out) experiment started. However, these prescribed soil moisture contents, soil temperatures, and the duration of the preincubation period varied significantly. In any case, the above mentioned requisite four experiments (exp. 1 to exp. 4) have

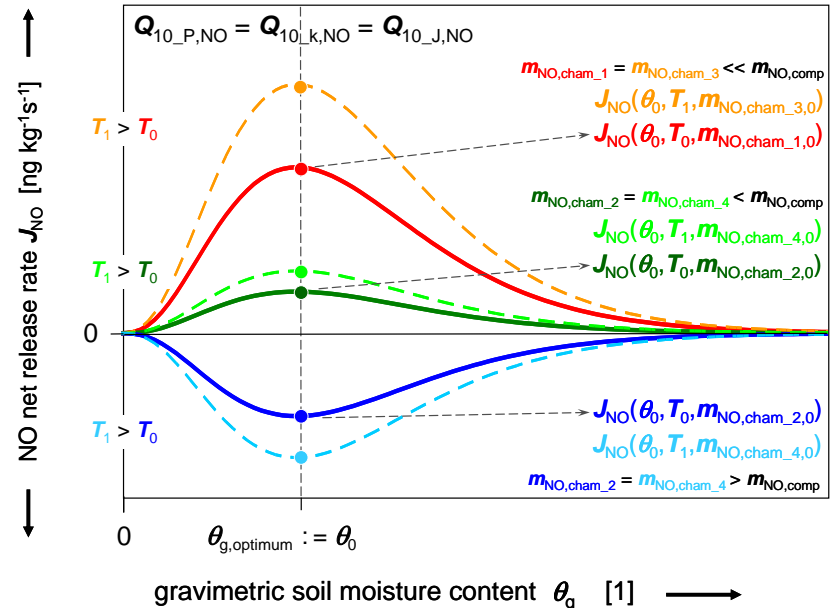

Figure 4. Schematic of NO net release rate $\left(J_{\mathrm{NO}}\right)$ variations, which should be observed under different conditions of gravimetric soil moisture $\left(\theta_{\mathrm{g}}\right)$, soil temperature $\left(T_{\mathrm{soil}}\right)$, and the dynamic chamber's headspace NO mixing ratio $\left(m_{\mathrm{NO}}\right.$,cham $)$. Note that the shown variations of $J_{\mathrm{NO}}$ with $T_{\text {soil }}$ are only valid, if $Q_{10 \_\mathrm{P}, \mathrm{NO}}=Q_{10 \_\mathrm{k}, \mathrm{NO}}$; then, also $Q_{10 \_ \text {J,NO }}=Q_{10 \_ \text {P,NO }}=Q_{10 \_ \text {k,NO}}$, see Eq. $3 \mathrm{~b}$ ).

been performed on four individual sub-samples of the original bulk soil sample. While van Dijk and Meixner (2001) observed good agreement between the measured net NO release rates of soil sub-samples, Gelfand et al. (2009), and Bargsten et al. (2010) found under certain circumstances great differences between $\theta_{0}$ and $\theta_{\mathrm{g}, 1}$, as well as between $J_{\mathrm{NO}}\left(\theta_{0}, T_{0}\right)$ and $J_{\mathrm{NO}}\left(\theta_{0}, T_{1}\right)$ of individual sub-samples. These differences became substantial as (i) the organic content of the soil increased (e.g. forest soils), or (ii) the NO consumption rate decreased (particularly in arid and hyperarid soils). Corresponding examples are presented in Figs. 5 and 6. Replicate measurements of $J_{\mathrm{NO}}\left(\theta_{\mathrm{g}}, T_{0}=25^{\circ} \mathrm{C}\right)$ at $m_{\mathrm{NO}, \text { in_1 }} \approx 0 \mathrm{ppb}$ of two mechanically homogenised rain forest soil sub-samples from Suriname show substantial difference of $\theta_{0}(0.56$ vs. 0.69$)$ and $\theta_{\mathrm{g}, 1}\left(0.83\right.$ vs. $\left.1.21 ; R_{J}=10\right)$, while the difference of $J_{\mathrm{NO}}\left(\theta_{0}, T_{0}\right)$ from the two experiments is small. For the results shown in Fig. 6, twelve individual experiments have been performed for a desert soil from Mongolia, three replicates each for the four conditions of exp. 1-exp. 4. The differences with respect to $\theta_{0}$ and $\theta_{\mathrm{g}, 1}$ might be acceptable; however, differences between net $\mathrm{NO}$ release rates measured under conditions of exp. 1exp. 4 contradict the methodical concept described above. Exponential increase of enzymatic activity with soil temperature necessitates that $J_{\mathrm{NO}}\left(\theta_{\mathrm{g}}, T_{1}, m_{\mathrm{NO}, \text { in_}_{-} 2}\right)>J_{\mathrm{NO}}\left(\theta_{\mathrm{g}}, T_{0}\right.$, $\left.m_{\mathrm{NO}, \text { in_1 } 1}\right)$ and $J_{\mathrm{NO}}\left(\theta_{\mathrm{g}}, T_{1}, m_{\mathrm{NO}, \text { in_4 }}\right)>J_{\mathrm{NO}}\left(\theta_{\mathrm{g}}, T_{0}, m_{\mathrm{NO}, \text { in_3 } 3}\right)$; linear increase of soil consumption with head space NO mixing ratio requires that $J_{\mathrm{NO}}\left(\theta_{\mathrm{g}}, T_{0}, m_{\mathrm{NO}, \text { cham }} 1\right)>J_{\mathrm{NO}}\left(\theta_{\mathrm{g}}\right.$, $\left.T_{0}, m_{\mathrm{NO}, \text { cham } \_2}\right)$ and $J_{\mathrm{NO}}\left(\theta_{\mathrm{g}}, T_{1}, m_{\mathrm{NO}, \text { cham } \_3}\right)>J_{\mathrm{NO}}\left(\theta_{\mathrm{g}}, T_{1}\right.$, $m_{\mathrm{NO}, \text { cham_4 }}$ ) (cf. Fig. 4). In Fig. 6, there are a dozen data points which contradict the first paradigm; however, 


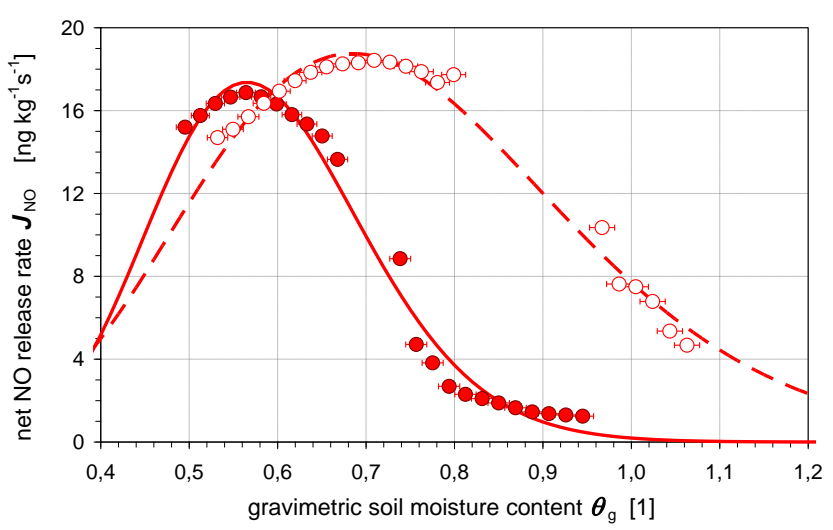

Figure 5. Results of two replicate NO net release rate $\left(J_{\mathrm{NO}}\right)$ measurements performed on two individual sub-samples of a organic rainforest soil from Suriname; both experiments have been performed at $T_{\text {soil }}=25^{\circ} \mathrm{C}$ and $m_{\mathrm{NO}, \text { in_ } 1}<0.15 \mathrm{ppb}$.

particularly for $\theta_{\mathrm{g}}<0.03$, fumigation with high NO mixing ratios (144 and $134 \mathrm{ppb}$ ) result in considerably higher net NO release rates than for those obtained under zero-air fumigation: an obvious contradiction to the second paradigm.

It has been suspected that (i) non-standardised preincubation procedures (s. Gödde and Conrad, 1999), and (ii) variability of nutrients and microbial composition in the soil sub-samples (still existing even after mechanical homogenisation) might be the most important reasons for contradicting results as shown in Figs. 5 and 6. To tackle these hypotheses, two decisions have been made for this study: (i) to omit any pre-incubation of soil samples (but applying a simple standardised procedure for initial wetting of the soil samples), and (ii) to re-design and improve the existing laboratory dynamic chamber system in a way that exp. 1-exp. 4 could be performed during one individual drying-out experiment on one soil sample only. Particularly the latter posed two major technical challenges, namely (i) the control of the soil temperature (via the temperature controlled cabinet) must allow the frequent (and fast) change at least between two temperatures differing by $10 \mathrm{~K}\left(T_{0}\right.$ and $\left.T_{1}\right)$ during an individual drying-out experiment, and (ii) the repeated and fast change of the incoming NO mixing ratio between zero air $\left(m_{\mathrm{NO}, \text { in_1 }}, m_{\mathrm{NO}, \text { in_3 }}\right)$ and a prescribed high level $\left(m_{\mathrm{NO}, \text { in_} \_2}\right.$, $\left.m_{\mathrm{NO} \text {,in_4 }}\right)$ also during the individual drying-out experiment. Temporal changes and equilibration of both $T_{\text {soil }}$ and $m_{\mathrm{NO}}$, in must be so fast that during one drying-out experiment for each of the conditions of exp. 1-exp. 4 (formerly individually applied to four individual soil sub-samples) a sufficient number of data points would be available to establish experimentally reliable relations between the corresponding net $\mathrm{NO}$ release rate and the three variables $\theta_{\mathrm{g}}, T_{\text {soil }}$, and $m_{\mathrm{NO}}$,cham . Besides these technical aspects, it had to be tested whether these repeated changes of environmental conditions would stress the microbial community.

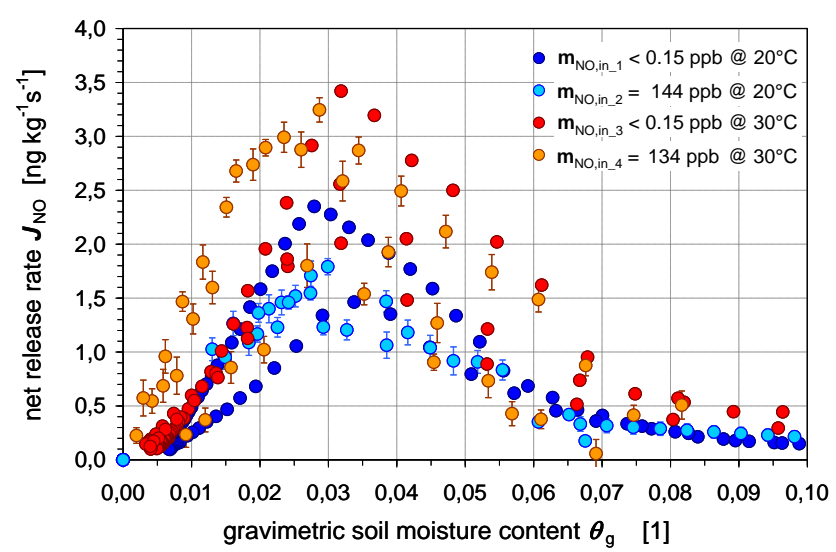

Figure 6. Results of individual NO net release rate $\left(J_{\mathrm{NO}}\right)$ measurements performed on 12 sub-samples of a desert soil from Mongolia; three replicates have been measured for each of the four measurement conditions indicated by the four different colours of shown data points.

Two additional technical facilities were implemented during the re-design of the laboratory dynamic chamber system, (i) humidification of the incoming air, and (ii) the temporal "switch" of the laboratory chamber system from the state of a dynamic chamber into a static chamber. The first facility accounts for the need to slow down the drying-out of the enclosed soil sample in order to get a temporally higher resolution of data points under quasi-constant $\theta_{\mathrm{g}}$ conditions, particularly for arid and hyper-arid soils where $\theta_{0}$ usually occurs below 0.1 . The second facility allows quantification of the emission of carbon dioxide $\left(\mathrm{CO}_{2}\right)$ which is usually used as proxy for microbial activity in the soil. There is wide evidence that the release of gaseous $\mathrm{N}$ is strongly coupled to the release of gaseous C (Stark et al., 2002; Dunfield and Knowles, 1998; Gödde and Conrad, 2000). However, small amounts of $\mathrm{CO}_{2}$ release from less than $0.1 \mathrm{~kg}$ soil sample and the limited precision of $\mathrm{CO}_{2}$ analysers do not allow application of the dynamic chamber technique.

\section{Material and methods}

\subsection{Soil sampling and preparation of soil samples}

The soil samples analysed in this study cover a large range of soil properties to demonstrate the improvement of the analysis of NO production, NO consumption, the NO compensation mixing ratio, and the release rate of $\mathrm{CO}_{2}$ by the new laboratory system. The capability of the system to study release rates of other trace gases (volatile organic compounds, VOC) in parallel is also demonstrated as this provides a valuable new tool for understanding the processes underlying $\mathrm{NO}$ emission. Consequently, the selection of soil samples to be used for this study was guided by most contrasting soil properties (see Table 1). For instance, soil $\mathrm{pH}$ of the samples 
Table 1. Compilation of soil properties of all soil samples used in this study. All soil samples have been taken from the top soil of corresponding ecosystems $(0-5 \mathrm{~cm}$ depth).

\begin{tabular}{|c|c|c|c|c|c|c|c|c|c|c|}
\hline \multirow{2}{*}{$\begin{array}{l}\text { Sample } \\
\text { ID }\end{array}$} & \multirow{2}{*}{$\begin{array}{l}\text { Eco- } \\
\text { system }\end{array}$} & \multicolumn{2}{|c|}{ Coordinates } & \multirow{2}{*}{$\begin{array}{l}\mathrm{pH} \\
{[1]}\end{array}$} & \multirow{2}{*}{$\begin{array}{l}\text { soil } \\
\text { type }\end{array}$} & \multirow{2}{*}{$\begin{array}{l}\mathrm{NH}_{4}^{+} \\
\left(\mathrm{mg} \mathrm{kg}^{-1}\right) \\
(\mathrm{N})\end{array}$} & \multirow{2}{*}{$\begin{array}{l}\mathrm{NO}_{3}^{-} \\
\left(\mathrm{mg} \mathrm{kg}^{-1}\right) \\
(\mathrm{N})\end{array}$} & \multirow{2}{*}{$\begin{array}{l}\text { Total N } \\
(\%)\end{array}$} & \multirow{2}{*}{$\begin{array}{l}\text { Total C } \\
(\%)\end{array}$} & \multirow{2}{*}{$\begin{array}{l}J_{\mathrm{CO}_{2}}\left(\theta_{0}, T_{0}\right)^{\mathrm{b}} \\
\left(\mathrm{ng} \mathrm{kg}^{-1} \mathrm{~s}^{-1}\right) \\
\text { (C) }\end{array}$} \\
\hline & & $\begin{array}{l}\text { latitude } \\
\left({ }^{\circ} \mathrm{N}\right)\end{array}$ & $\begin{array}{l}\text { longitude } \\
\left({ }^{\circ} \mathrm{E}\right)\end{array}$ & & & & & & & \\
\hline $\begin{array}{l}\text { MONGOLIA desert } \\
\text { (Mongolia) }\end{array}$ & $\begin{array}{l}\text { hyper-arid } \\
\text { desert }\end{array}$ & 44.1367 & 96.6314 & 7.9 & $\begin{array}{l}\text { sandy } \\
\text { loam }\end{array}$ & 0.64 & 68.80 & $<0.05$ & 0.96 & $105.6^{\mathrm{d}}$ \\
\hline $\begin{array}{l}\text { KUCHE corn } \\
\text { (Xinjiang, China) }\end{array}$ & $\begin{array}{l}\text { arid oasis } \\
\text { agriculture }\end{array}$ & 41.5358 & 82.855 & 8.3 & $\begin{array}{l}\text { silty } \\
\text { loam }\end{array}$ & 2.16 & 105.62 & 0.11 & 4.89 & n. a. \\
\hline $\begin{array}{l}\text { KUCHE wheat } \\
\text { (Xinjiang, China) }\end{array}$ & $\begin{array}{l}\text { arid oasis } \\
\text { agriculture }\end{array}$ & 41.5357 & 82.8541 & 8.0 & $\begin{array}{l}\text { silty } \\
\text { loam }\end{array}$ & 2.27 & 54.32 & 0.09 & 4.77 & n. a. \\
\hline $\begin{array}{l}\text { FINTHEN grassland } \\
\text { (Germany) }\end{array}$ & $\begin{array}{l}\text { grass-land } \\
\text { steppe }\end{array}$ & 49.9685 & 8.1479 & 6.2 & loam & 7.00 & 2.20 & 0.31 & 4.54 & n. a. \\
\hline $\begin{array}{l}\text { SURINAME rainforest } \\
\text { (Suriname) }\end{array}$ & rainforest $^{\mathrm{a}}$ & 05.0763 & -55.0029 & 4.0 & - & 83.40 & 4.88 & 0.59 & 8.12 & 416.7 \\
\hline $\begin{array}{l}\text { EGER blueberry } \\
\text { (Germany) }\end{array}$ & $\begin{array}{l}\text { spruce } \\
\text { forest }\end{array}$ & 50.1425 & 11.8665 & 3.2 & - & 239.6 & 36.9 & 1.89 & 41.00 & 2824 \\
\hline $\begin{array}{l}\text { EGER spruce } \\
\text { (Germany) }\end{array}$ & $\begin{array}{l}\text { spruce } \\
\text { forest }\end{array}$ & 50.1420 & 11.8673 & 3.0 & - & 982.6 & 90.2 & n. d. & $43.84^{b}$ & 5641 \\
\hline
\end{tabular}

${ }^{a}$ From Oswald et al. (2013). ${ }^{\mathrm{b}} \theta_{0}$ : optimum gravimetric soil moisture content of net NO release rate. ${ }^{\mathrm{c}}$ Data obtained by "loss on ignition" measurements (conversion factor: 2.13 ).

${ }^{\mathrm{d}}$ Calculated data statistically not significant $\left(\Delta m_{\mathrm{CO}_{2}} / \Delta t\right.$ not significantly different from zero (see Eq. 25).

ranges from 3.2 (mid-latitude spruce forest soil, "EGER blueberry") to 8.3 (arid oasis cornfield soil, "KUCHE corn"), ammonium and nitrate contents of the hyper-arid ("MONGOLIA desert"), arid cornfield and arid wheatfield soils are characterised by very low soil $\mathrm{NH}_{4}^{+}$concentrations $(0.64$, 2.16 , and $2.27 \mathrm{~m} \mathrm{~kg}^{-1}$ (in terms of $\mathrm{N}$ ), and high soil $\mathrm{NO}_{3}^{-}$ concentrations $\left(68.80,105.62\right.$, and $54.32 \mathrm{mg} \mathrm{kg}^{-1}$; in terms of $\mathrm{N}$ ), respectively.

Mechanical homogenisation of root free soil by sieving was only applied to field-fresh soil samples, since drying inevitably alters the microbial community significantly (Thomson et al., 2010). To minimise these effects on the net NO release rate, fresh soil was passed through 2 and $16 \mathrm{~mm}$ mesh sieves for mineral (Feig et al., 2008a) and organic soils (Bargsten et al., 2010), respectively. In the field, soil was sampled from 0 to $0.05 \mathrm{~m}$ and mid-latitude samples were measured immediately, while dryland soils were stored in the dark at $4{ }^{\circ} \mathrm{C}$ at very low field moisture content $\left(<0.02 \theta_{\mathrm{g}}\right)$ until analysis. Storage for up to 3 months at $4{ }^{\circ} \mathrm{C}$ is not supposed to lead to microbial alterations (Stotzky et al., 1962).

Mechanically homogenised soil samples of $0.06 \mathrm{~kg}$ each were placed into six Plexiglas chambers (inner diameter: $0.092 \mathrm{~m}$; height: $0.136 \mathrm{~m}$ ) and wetted up to water holding capacity $(1.8 \mathrm{pF})$. This procedure has been chosen, since the gravitational water in the wide macropores will drain a short time after rainfall (up to 2-3 days) and only the water in the smaller macropores, medium pores, and micropores will be available. Therefore, water holding capacity is used within this study as a maximum wetting value. Furthermore, water holding capacity can easily be measured by the so-called filter method (Whatman-filter paper no. 42). As performed in earlier studies (Remde et al., 1989, 1993), we preferred to omit any pre-incubation of the soil samples to come as close as possible to natural field conditions. Therefore, net NO release rates in the dynamic chamber system were always measured immediately after the adjustment to water holding capacity until the soil was completely dried out. Nevertheless, since six chambers are prepared for one experiment, 30 minutes were necessary for equilibration of soil temperature, headspace humidity, and NO mixing ratio.

\subsection{Laboratory chamber system: set-up}

The new laboratory chamber system is shown in Fig. 7. The system consists of four units: "gas dilution", "thermostat valve", "thermostat cabinet", and "analysers", which are briefly described below (for detailed description, see Sect. 1 of the Supplement). For clarity only two soil chambers are shown in Fig. 7, one reference cell and one soil sample, although there are six chambers in all.

\subsubsection{The gas dilution unit}

Pressurised air is passed through a so-called "purified air generator" (PAG 003, Ecophysics, Switzerland) to filter out particles $(<7 \mu \mathrm{m})$, water vapour $\left(-30^{\circ} \mathrm{C}\right.$ dew point $), \mathrm{NO}_{\mathrm{x}}$, $\mathrm{SO}_{2}$, ozone $(<10 \mathrm{ppt})$, as well as hydrocarbons and $\mathrm{CO}$ $(<3 \mathrm{ppb})$. Different (pre-set) NO mixing ratios for flushing the soil chambers are generated by diluting known amounts of NO from a standard gas cylinder $(200 \mathrm{ppm}$, Air Liquide, Germany) through the mass flow controller (NO MFC, $0-10 \mathrm{~cm}^{3} \mathrm{~min}^{-1}$; Bronckhorst, Germany) into the zero airstream. During the entire drying-out experiment, the dilution of NO must be continuously maintained to guarantee stable NO mixing ratios of the flushing airstream. For that 


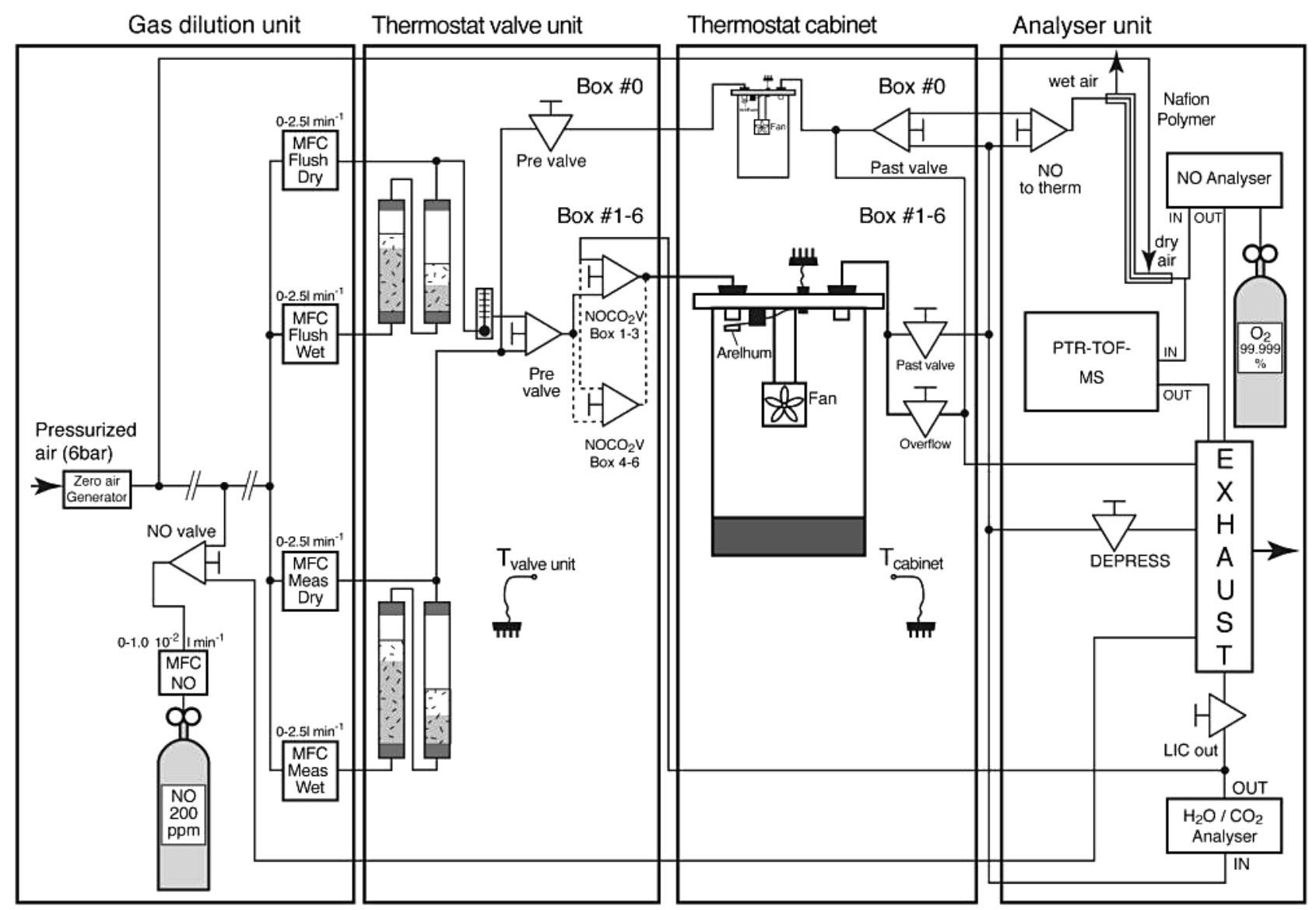

Figure 7. Schematic of the improved laboratory dynamic chamber system, consisting of four units: "gas dilution", "thermostat valve", "thermostat cabinet", and "analysers". For simplification only two soil chambers are shown in the figure: one reference cell and one soil sample, although there are six soil chambers in all.

a valve is placed after NO MFC, to waste the continuous flow of NO to the exhaust in the analyser unit, in case zeroair flushing of the chambers is applied. There are ca. $3 \mathrm{~m}$ of PTFE tubing $(6.35 \mathrm{~mm}$ o.d.) between the NO valve and the downstream MFCs to allow for complete mixing of zero air and NO from the standard cylinder. At this point, the flushing airstream is divided into four sub-streams: two dry gas streams controlled by MFC Meas Dry and by MFC Flush Dry, as well as two wet gas streams controlled by MFC Meas Wet and MFC Flush Wet (all 4 MFCs: 0-2.5 $\mathrm{L} \mathrm{min}^{-1}$ or $4.16667 \times 10^{-5} \mathrm{~m}^{3} \mathrm{~s}^{-1}$; Bronckhorst, Germany).

\subsubsection{The thermostat valve unit}

Within the Thermostat valve unit, the air downstream of MFC Meas Wet and MFC Flush Wet are directed into two humidifiers. Downstream of these devices, dry and wet streams are mixed together to the Meas gas stream and the Flush gas stream, respectively. By proper pre-set of MFC Meas Wet and MFC Flush Wet, the water vapour content of both, the Meas gas and the Flush gas stream can be controlled from 0 to $95 \%$ relative humidity (see Sect. S1 of the Supplement). The Meas flow of $2.5 \mathrm{~L} \mathrm{~min}^{-1}$ is led through that soil chamber (via the Pre valve), whose headspace mixing ratio is actually measured. The Flush flow of $2.5 \mathrm{~L} \mathrm{~min}^{-1}$ is again split up by flow controllers (Omega ${ }^{\circledR}$, USA) to flush the remaining five chambers (with $0.5 \mathrm{~L} \mathrm{~min}^{-1}$; the reference chamber, containing soil sample was not flushed). To avoid condensation effects, the temperature of the Thermostat valve unit is continuously maintained at $40^{\circ} \mathrm{C}$.

\subsubsection{The thermostat cabinet unit}

The pre and past valve are switched in such a way that the Meas flow is passing through the different chambers and subsequently detected by the NO, PTR-TOF-MS, and $\mathrm{H}_{2} \mathrm{O} / \mathrm{CO}_{2}$ analyser. In the dynamic chamber mode, which is used for the measurement of net release rates, the chosen combination of chamber volume $\left(9.1405 \times 10^{-4} \mathrm{~m}^{3}\right)$ and flushing rate $\left(4.16667 \times 10^{-5} \mathrm{~m}^{3} \mathrm{~s}^{-1}\right)$ leads to a very short residence time of the air within the chamber (22s). Given an incoming $\mathrm{CO}_{2}$ mixing ratio of $m_{\mathrm{CO}_{2} \text {, cham }} 1$ $\approx 350 \mathrm{ppm}$, this 
residence time has been repeatedly observed to be not long enough that the $\mathrm{CO}_{2}$ respiration (from $0.06 \mathrm{~kg}$ of soil) may

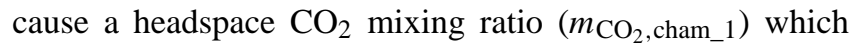
can be measured as significantly different from the incoming $\mathrm{CO}_{2}$ mixing ratio (on the basis of common $\mathrm{CO}_{2}$ analysers' precision, ca. $0.5 \mathrm{ppm}$ ). Consequently, the static mode facility has been implemented in the new design of our laboratory chamber system in order to measure the release rate of $\mathrm{CO}_{2}$ (and potential other trace gases of low soil emission and/or insufficient analyser's precision). In this mode that chamber, which is actually being probed, is "closed", i.e. the headspace air is cycled (and analysed for its increasing $\mathrm{CO}_{2}$ mixing ratio) for $3.5 \mathrm{~min}$ from the chamber's headspace, via corresponding tubing into the measurement cell of the $\mathrm{CO}_{2}$ analyser (see below) and back. In order to change the system from the dynamic into static mode, first the NO and NOtoTherm valves are switched to allow the Meas flow to pass the NO-analyser and change the incoming mixing ratio of NO. After the incoming mixing ratio of NO is stable (usually $3.5 \mathrm{~min}$ ), the "LIC_out", "NOCO${ }_{2}$ ", and overflow valves for the corresponding box (1-6), are switched to allow the Flush flow to pass the $\mathrm{CO}_{2}$ analyser. The chamber system stays only in the static mode, after the incoming NO mixing ratio has just been switched from zero air ( $m_{\mathrm{NO} \text {,in_1 }}$ or $\left.m_{\mathrm{NO} \text {,in_3 }}\right)$ to the high mixing ratio level $\left(m_{\mathrm{NO}, \text { in_2 } 2}\right.$ or $\left.m_{\mathrm{NO}, \text { in } \_4}\right)$ and vice versa: after the stabilisation time, the mixing ratio of $\mathrm{CO}_{2}$ of the six soil chambers is measured for $4 \mathrm{~min}$ in the static mode, while the NO mixing ratio of the reference chamber is monitored (for details, see Sect. 1 of the Supplement). When the NO mixing ratio of the Meas flow is stabilised, the measurement of the temporal increase of $\mathrm{CO}_{2}$ mixing ratio in the soil chambers is completed; the $\mathrm{NOCO}_{2}$ and NOtoTherm valves are switched again to operate the system back to the dynamic mode.

\subsubsection{The analyser unit}

The analysers for the measurement of $\mathrm{NO}, \mathrm{CO}_{2}, \mathrm{H}_{2} \mathrm{O}$, and VOC mixing ratios in the incoming and chamber headspace air are as follows: (i) chemiluminescence (gas-phase) $\mathrm{NO}_{\mathrm{x}}$ analyser (Model 42i-TL, Thermo Fisher Scientific Inc., USA), (ii) $\mathrm{CO}_{2} / \mathrm{H}_{2} \mathrm{O}$ non-dispersive infrared (NDIR) analyser (Model LI-COR 840A, LI-COR Biosciences Inc., USA), and (iii) proton transfer time of flight mass spectrometer (PTR-TOF-MS 8000, IONICON, Austria).

For the $\mathrm{NO}_{\mathrm{x}}$-analyser, dry oxygen $(99.999 \%)$ is used to photolytically generate ozone that reacts in the instrument's reaction cell (at ca. $30 \mathrm{hPa}$ ) with the $\mathrm{NO}$ of the sample air to form electronically excited $\mathrm{NO}_{2}$ molecules. The decay to the ground state is accompanied by photon emission (chemiluminescence proportional to NO mixing ratio) which is subsequently detected by a photomultiplier. The $\mathrm{NO}_{\mathrm{x}}$ analyser is regularly calibrated using a commercial gas-dilution device (146C Dynamic Gas Calibrator, Thermo Fisher Scientific Inc., USA) where known amounts of NO from a pressurised standard cylinder ( 5 ppm; Air Liquide, Germany) are diluted into NO free zero air. From these calibrations the limit of detection (LOD) and the precision (from LOD to $500 \mathrm{ppb}$ ) of the analyser have been determined (see Sect. 4).

In the dual channel NDIR- $\mathrm{CO}_{2} / \mathrm{H}_{2} \mathrm{O}$ analyser sample airflows through a measurement cell consisting of an optical bench with an infrared source, $\mathrm{CO}_{2}$ filters (3.95 $\times 10^{-6} \mathrm{~m}$ reference and $4.26 \times 10^{-6} \mathrm{~m}$ sample), $\mathrm{H}_{2} \mathrm{O}$ filters $\left(2.35 \times 10^{-6} \mathrm{~m}\right.$ reference and $2.59 \times 10^{-6} \mathrm{~m}$ sample $)$, and detector. The mixing ratios of $\mathrm{CO}_{2}$ and $\mathrm{H}_{2} \mathrm{O}$ are inferred from the difference in infrared absorption between the sample gas and the internally generated reference gas (free of $\mathrm{CO}_{2}$ and $\mathrm{H}_{2} \mathrm{O}$ ). For the calibration of the $\mathrm{CO}_{2} / \mathrm{H}_{2} \mathrm{O}$ analyser, three gaseous $\mathrm{CO}_{2}$ standards were used (356.9, 457.3, and $551 \mathrm{ppm}$; Air Liquide, Germany). For these calibration mixing ratios, corresponding relative precision $\left(\sigma_{\mathrm{m}, \mathrm{CO}_{2}} / m_{\mathrm{CO}_{2}}\right)$ of the analyser has been determined to 3.15 , 1.68 , and $1.54 \times 10^{-3}$, respectively.

Measurements of volatile organic compounds (VOC) were performed using a commercial PTR-TOF-MS instrument (Ionicon Analytik GmbH, Innsbruck, Austria, see Grauss et al., 2010). The detection principle relies on the protonation of ambient VOCs by $\mathrm{H}_{3} \mathrm{O}^{+}$-ions (which are generated in a hollow cathode discharge) that are subsequently detected by mass spectrometry. Such systems can typically measure protonated VOCs with at a detection limit of about 10-100 ppt (Lindinger et al., 1998). The PTR-TOF-MS offers a mass resolution of ca. $3700 \mathrm{~m} / \Delta \mathrm{m}$. Mass spectra were collected ranging from $m / z=10$ to 500 . The instrument was operated with a drift voltage of $600 \mathrm{~V}$ and a drift pressure of $2.20 \mathrm{mbar}$ (E/N $140 \mathrm{Td}$ ). Internal mass calibration of the PTR-TOF-MS was performed by permeating 1,3,5-trichlorobenzene into a $1 \mathrm{~mm}$ section of $1.58 \mathrm{~mm}$ o.d. Teflon tubing used in the inlet flow system controlled to $60^{\circ} \mathrm{C}$. Post-acquisition data analysis was performed according to procedures described elsewhere (Müller et al., 2010, 2011, 2013; Titzmann et al., 2010). Standards for acetone and acetaldehyde were available from commercial pressurised standard gas cylinders (Apel-Riemer Environmental). The dynamic chamber system provides a Meas flow of $2.5 \mathrm{~L} \mathrm{~min}^{-1}$, where the $\mathrm{NO}_{\mathrm{x}}$ analyser receives about $1.3 \mathrm{~L} \mathrm{~min}^{-1}$, the $\mathrm{CO}_{2} / \mathrm{H}_{2} \mathrm{O}$ analyser about $0.5 \mathrm{~L} \mathrm{~min}^{-1}$, and the PTR-TOF-MS about $0.1 \mathrm{~L} \mathrm{~min}^{-1}$; the rest is wasted to the exhaust. The LOD for the PTR-TOFMS for $\mathrm{C}_{2} \mathrm{H}_{4} \mathrm{O}$ and $\mathrm{C}_{3} \mathrm{H}_{6} \mathrm{O}$ was determined as $1 \sigma$ noise (during calibration by standard gas) as 0.081 and $0.024 \mathrm{ppb}$, respectively.

Since the signal of the $\mathrm{NO}_{\mathrm{x}}$ analyser (see below) is somewhat sensitive to changing water vapour concentrations (originating from evaporation of the enclosed soil sample), a certain amount of the purified and dry airstream (see gas dilution unit) was used to continuously flush the outer tube of the $3.6 \mathrm{~m}$ Nafion ${ }^{\circledR}$ inverted gas dryer (Model Perma Pure $\mathrm{MD}^{\mathrm{TM}}$ 110, Perma Pure LLC, USA). To avoid gas diffusion from the NO standard gas cylinder (200 ppm, Air Liquide, Germany) into the dryer, ca. $3 \mathrm{~m}$ of PTF tubing (6.35 mm o.d.) separates 
the T-connector and the NO mass flow controller NO MFC. In order to avoid pressure pulses within the complex valve switching framework of the our laboratory chamber system, the "Depress" valve has been integrated, which is opened before and closed after each operation of any switching valves.

\subsection{Determination of the gravimetric soil moisture}

Suitable sensors for direct measurement of the gravimetric soil moisture content of the small $(0.06 \mathrm{~kg})$ enclosed soil sample are currently not available. Therefore, high-precision determination of the actual gravimetric soil moisture content is indirectly achieved by considering the mass balance of $\mathrm{H}_{2} \mathrm{O}$ vapour of the dynamic chamber. A detailed description is given in Sect. 2 of supplement. During the entire drying-out experiment, $\mathrm{H}_{2} \mathrm{O}$ vapour in the incoming flushing airstream, $s_{\mathrm{H}_{2} \mathrm{O} \text {,in }}(t)$, and in the well-mixed headspace of the laboratory dynamic chamber, $s_{\mathrm{H}_{2} \mathrm{O} \text {, cham }}(t)$, is measured by the $\mathrm{CO}_{2} / \mathrm{H}_{2} \mathrm{O}$ NDIR analyser. In case of flushing the chambers with dry air, the presence of $\mathrm{H}_{2} \mathrm{O}$ vapour in the chamber's headspace is exclusively due to evaporation from the (initially wetted) soil sample, which in turn diminishes the (gravimetric) soil moisture content of the soil sample (in case of flushing the chambers with humidified air, the decrease of $\mathrm{H}_{2} \mathrm{O}$ vapour is exclusively due to absorption in the (initially dry) soil sample). For the sake of convenience, data of $\mathrm{H}_{2} \mathrm{O}$ vapour are considered only in terms of the mea-

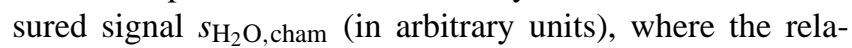
tion between $s_{\mathrm{H}_{2}} \mathrm{O}$, cham and the $\mathrm{H}_{2} \mathrm{O}$ vapour concentration is given by $c_{\mathrm{H}_{2} \mathrm{O} \text {, cham }}(t)=g s_{\mathrm{H}_{2} \mathrm{O} \text {, cham }}(t)$. The proportionality constant $g$ is "calibrated" by the temporally integrated $\mathrm{H}_{2} \mathrm{O}$ vapour signal which is directly related to the amount of evaporated soil water; the latter is simply determined by weighing the soil sample before and after the experiment. Hence, the proportionality constant $g$ is given by

$g=\frac{m_{\text {soil }}\left(t_{S}\right)-m_{\text {soil }}\left(t_{0}\right)}{V\left[s_{\mathrm{H}_{2} \mathrm{O}, \text { cham }}\left(t_{S}\right)-s_{\mathrm{H}_{2} \mathrm{O}, \text { cham }}\left(t_{0}\right)\right]+S_{0}}$,

where $V$ is the volume of the chamber $\left(\mathrm{m}^{3}\right), m_{\text {soil }}\left(t_{0}\right)$ and $m_{\text {soil }}\left(t_{\mathrm{S}}\right)$, given in $\mathrm{kg}$, is the total mass of the soil sample at the begin $\left(t=t_{0}\right)$ and the end $\left(t=t_{S}\right)$ of the drying-out experiment, $s_{\mathrm{H}_{2} \mathrm{O} \text {, cham }}\left(t_{0}\right)$, and $s_{\mathrm{H}_{2} \mathrm{O} \text {, cham }}\left(t_{S}\right)$ are the corresponding $\mathrm{H}_{2} \mathrm{O}$ signals (arbitrary units), and $S_{0}$ is an integration constant (Eq. S3.4, see Sect. S.1 of the Supplement). At any time, $t_{i}$, during the drying-out experiment the total mass of the enclosed soil sample $m_{\text {soil }}\left(t_{i}\right)$ is then given by

$m_{\text {soil }}\left(t_{i}\right)=m_{\text {soil }}\left(t_{i-1}\right)+$
$V g\left[s_{\mathrm{H}_{2} \mathrm{O}, \text { cham }}\left(t_{i}\right)-s_{\mathrm{H}_{2} \mathrm{O}, \text { cham }}\left(t_{i-1}\right)\right]+S_{i}$,

where

$S_{i}=\left(T_{i}+T_{i-1}\right)\left[s_{\mathrm{H}_{2} \mathrm{O}, \mathrm{cham}}\left(t_{i-1}\right)-s_{\mathrm{H}_{2} \mathrm{O}, \text { in }}\left(t_{i-1}\right)\right] ;$

$T_{i}=\frac{t_{i}-t_{i-1}}{2} ; T_{0}=T_{S+1}=0$.
The dimensionless gravimetric soil moisture is defined by $\theta_{\mathrm{g}}=\left(m_{\text {soil,wet }}-m_{\text {soil,dry }}\right) / m_{\text {soil,dry }}$. Hence, during the entire period of drying-out a soil sample in the laboratory dynamic chamber, the actual gravimetric soil moisture $\theta_{\mathrm{g}}\left(t_{i}\right)$ is then given by

$\theta_{\mathrm{g}}\left(t_{i}\right)=\frac{m_{\mathrm{soil}}\left(t_{i}\right)-m_{\mathrm{soil}}\left(t_{S}\right)}{m_{\text {soil }}\left(t_{S}\right)}$.

\subsection{Calculation of release rates of $\mathrm{NO}, \mathrm{CO}_{2}$, $\mathrm{C}_{2} \mathrm{H}_{4} \mathrm{O}$, and $\mathrm{C}_{3} \mathrm{H}_{6} \mathrm{O}$}

Most analysers provide measurement data in units of the dimensionless volume mixing ratio of the corresponding trace gas $i\left(m_{i}\right.$ in $\left.10^{-9}=\mathrm{ppb}\right)$, while for the calculation of release rates $\left(J_{i}\right.$ in $\left.\mathrm{ng} \mathrm{kg}_{\text {dry soil }}^{-1} \mathrm{~s}^{-1}\right)$ concentration units $\left(c_{i}\right.$ in $\mathrm{ng} \mathrm{m}^{-3}$ ) have to be used. Therefore, appropriate conversion factors $f_{C, i}$ are necessary:

$c_{i}=f_{\mathrm{C}, i} m_{i}=10^{3} \frac{\rho_{\mathrm{air}} M_{i}}{M_{\text {air, dry }}} m_{i}$,

where $\rho_{\text {air }}$ is the mean dry air density $\left(\mathrm{kg} \mathrm{m}^{-3}\right), M_{i}$ is the atomic/molecular weight of the considered trace gas $i$ ( $\mathrm{kg} \mathrm{kmole}^{-1}$ ), and $M_{\text {air,dry }}$ is the molecular weight of dry air $\left(M_{\text {air,dry }}=28.9644 \mathrm{~kg} \mathrm{kmole}^{-1}\right)$. Release rates and fluxes of $\mathrm{NO}$ are often expressed in terms of mass of atomic nitrogen $M_{\mathrm{N}}=14.0067 \mathrm{~kg} \mathrm{kmole}^{-1}$ ), because this enables easy comparison with corresponding soil related fluxes and release rates of nitrous oxide $\left(\mathrm{N}_{2} \mathrm{O}\right)$, nitrogen dioxide $\left(\mathrm{NO}_{2}\right)$, nitrous and nitric acid $\left(\mathrm{HONO}\right.$ and $\left.\mathrm{HNO}_{3}\right)$, as well as ammonia $\left(\mathrm{NH}_{3}\right)$. Analogously, the corresponding quantities for $\mathrm{CO}_{2}, \mathrm{C}_{2} \mathrm{H}_{4} \mathrm{O}$, and $\mathrm{C}_{3} \mathrm{H}_{6} \mathrm{O}$ are expressed in terms of the atomic weight of carbon $\left(M_{\mathrm{C}}=12.0107 \mathrm{~kg} \mathrm{kmole}^{-1}\right)$. Here, the mean air density $\rho_{\text {air }}\left(\mathrm{kg} \mathrm{m}^{-3}\right)$ is dependent on air temperature of the chamber's headspace (the temperature controlled cabinet) according to

$\rho_{\text {air }}=\frac{100 p_{\text {air }} M_{\text {air, dry }}}{R\left(273.15+T_{\text {headspace }}\right)}$,

where $p_{\text {air }}$ is the barometric pressure $(\mathrm{hPa}), R$ the universal gas constant (8314.41 $\mathrm{J} \mathrm{kmole}^{-1} \mathrm{~K}^{-1}\left(\mathrm{~N} \mathrm{~m} \mathrm{kmole}{ }^{-1} \mathrm{~K}^{-1}\right.$; $\mathrm{kg} \mathrm{m}^{2} \mathrm{kmole}^{-1} \mathrm{~K}^{-1} \mathrm{~s}^{-2}$, and $T_{\text {headspace }}$ the actual air temperature $\left({ }^{\circ} \mathrm{C}\right)$ of the chamber's headspace.

Considering the mass balance of the dynamic chamber (e.g. Meixner and Yang, 2006), the net release rate $\left(J_{i}\right)$ can be calculated from the chamber's purging rate $(Q$ in $\left.\mathrm{m}^{3} \mathrm{~s}^{-1}\right)$, the mass of the enclosed soil ( $m_{\text {soil }}$ in $\mathrm{kg}$ ), and the mixing ratio difference between the chamber's out- and inlet $\left(m_{i, \text { out }}-m_{i \text {,in }}\right.$ in $\left.\mathrm{ppb}\right)$. For the above described setup of our laboratory dynamic chamber system, $m_{i \text {,in }}$ is replaced by the mixing ratio measured in the reference chamber $\left(m_{i, \text { ref }}\right)$, and $m_{i \text {,out }}$ by the mixing ratio the chamber's headspace $\left(m_{i, \text { cham }}\right)$. The latter is justified by the effective mixing of the headspace's air by the fan and the high purging 
rate $Q$, i.e. short exchange time $\tau$ of the chamber's headspace volume). Then, $J_{i}$ is formulated as

$J_{i}=\frac{Q}{m_{\text {soil }}}\left(m_{i, \text { cham }}-m_{i, \text { in }}\right) f_{\mathrm{C}, i}$,

where $Q=4.16667 \times 10^{-5} \mathrm{~m}^{3} \mathrm{~s}^{-1}\left(=2.5 \mathrm{~L} \mathrm{~min}^{-1}\right)$ for each experiment of this study.

Formulas for the calculation of the net NO release rate $J_{\mathrm{NO}}$, the NO production rate $P_{\mathrm{NO}}$, the $\mathrm{NO}$ consumption rate $U_{\mathrm{NO}}$, the NO consumption coefficient $k_{\mathrm{NO}}$, and the $Q_{10}$ values for NO production and consumption are already given in Sect. 2 of this paper. Numeric expressions of optimum curve relationships between $J_{\mathrm{NO}}, k_{\mathrm{NO}}, P_{\mathrm{NO}}, U_{\mathrm{NO}}$, and gravimetric soil moisture content $\theta_{\mathrm{g}}$ have been obtained by fitting Eq. (9) to corresponding data points using the solver option of Microsoft ${ }^{\circledR}$ Office Excel.

Acetone $\left(\mathrm{C}_{2} \mathrm{H}_{4} \mathrm{O}\right)$ and acetaldehyde $\left(\mathrm{C}_{3} \mathrm{H}_{6} \mathrm{O}\right)$ are two of the VOC species which have been measured by PTR-TOFMS, which was calibrated by a commercially available, calibrated gas standard (see above). The PTR-TOF-MS signals are converted to corresponding mixing ratios by

$m_{\mathrm{VOC}}=\left(\frac{\mathrm{ncps}_{\mathrm{VOC}, \mathrm{cham}}-\mathrm{ncps}_{\mathrm{VOC}, \mathrm{in}}}{C_{\mathrm{f}, \mathrm{VOC}}}\right)$,

where $C_{\mathrm{f}, \mathrm{VOC}}$ is the VOC specific calibration factor, and ncpsVOC, in and ncpsVoC,cham are the normalised PTR-TOFMS signals (counts per second) at the inlet (measured from the reference chamber box0) and within the chamber's headspace, respectively. Analogously to the calculation of the net NO release rate, the release rate for VOCs (here: $\mathrm{C}_{2} \mathrm{H}_{4} \mathrm{O}$ and $\left.\mathrm{C}_{3} \mathrm{H}_{6} \mathrm{O}\right)$ is calculated as

$J_{\mathrm{VOC}}=\frac{Q\left(m_{\mathrm{VOC}, \text { cham }}-m_{\mathrm{VOC}, \text { in }}\right) f_{\mathrm{C}, \mathrm{VOC}}}{m_{\mathrm{soil}}}$,

where $Q$ is the flushing flow rate $\left(2.5 \mathrm{~L} \mathrm{~min}^{-1}\right.$ or $\left.4.16667 \times 10^{-5} \mathrm{~m}^{3} \mathrm{~s}^{-1}\right), m_{\text {soil }}$ the dry mass of soil $(\mathrm{kg})$, and

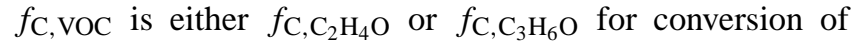
$\mathrm{C}_{2} \mathrm{H}_{4} \mathrm{O}\left(\mathrm{C}_{3} \mathrm{H}_{6} \mathrm{O}\right)$ mixing ratios (ppb) into $\mathrm{C}_{2} \mathrm{H}_{4} \mathrm{O}\left(\mathrm{C}_{3} \mathrm{H}_{6} \mathrm{O}\right)$ concentrations $\left(\mathrm{ng} \mathrm{m}^{-3}\right)$.

To determine the $\mathrm{CO}_{2}$ release rate $J_{\mathrm{CO}_{2}}$, the chamber system is operated in the static mode. Consequently, for calculation of $J_{\mathrm{CO}_{2}}$, the mass balance equation of the closed chamber has to be considered, i.e. the release rate is derived from the temporal change of the $\mathrm{CO}_{2}$ concentration in the total volume $V^{*}$ over the soil sample $\left(V^{*}=1.273 \times 10^{-3} \mathrm{~m}^{3}\right.$; i.e. chambers' volume + volume of tubing + volume of the $\mathrm{CO}_{2} / \mathrm{H}_{2} \mathrm{O}$ analyser's absorption cell):

$J_{\mathrm{CO}_{2}}=\frac{\left[m_{\mathrm{CO}_{2}, \text { cham }}\left(t_{1}\right)-m_{\mathrm{CO}_{2}, \operatorname{cham}}\left(t_{0}\right)\right] f_{\mathrm{C}, \mathrm{CO}_{2}}}{m_{\text {soil }}} \frac{V^{*}}{t_{1}-t_{0}}$,

where $m_{\mathrm{CO}_{2} \text {, cham }}\left(t_{1}\right)$ and $m_{\mathrm{CO}_{2} \text {, cham }}\left(t_{0}\right)$ are the $\mathrm{CO}_{2}$ mixing ratios (ppm) at $t_{1}$ and $t_{0}$, and $f_{\mathrm{C}, \mathrm{CO}_{2}}$ is the factor to convert the $\mathrm{CO}_{2}$ mixing ratio $(\mathrm{ppm})$ into $\mathrm{CO}_{2}$ concentration $\left(\mu \mathrm{g} \mathrm{m}^{-3}\right)$. Note that $t_{1}-t_{0}(=3.5 \mathrm{~min})$ is the duration of closing the respective soil chamber, see above).

\subsection{Error analysis}

The directly measured quantities in this study were the mixing ratios of $\mathrm{NO}, \mathrm{CO}_{2}, \mathrm{H}_{2} \mathrm{O}$, and VOCs in the flushing (incoming) airstream and within the chamber's headspace. Each chamber was measured for 4 minutes with temporally high resolution of $30 \mathrm{~s}$ for $\mathrm{NO}$, VOCs, $\mathrm{CO}_{2}$, and $\mathrm{H}_{2} \mathrm{O}$. Corresponding averages and standard deviations have been calculated of the last $90 \mathrm{~s} \mathrm{(3} \mathrm{data} \mathrm{points)} \mathrm{for} \mathrm{each} \mathrm{measurement.}$ Therefore, general Gaussian error propagation was applied to calculate the errors of all those quantities, which are derived from measured mixing ratios, i.e. net NO release rate $J_{\mathrm{NO}}$, NO consumption coefficient $k_{\mathrm{NO}}$, NO production rate $P_{\mathrm{NO}}$, NO consumption rate $U_{\mathrm{NO}}$, NO compensation point mixing ratio $m_{\mathrm{NO} \text { omp }}, Q_{10}$ values of $\mathrm{NO}$ production and $\mathrm{NO}$ consumption, the proportionality factor $g$, actual mass of enclosed soil sample $m_{\text {soil }}\left(t_{i}\right)$, actual gravimetric soil moisture $\theta_{\mathrm{g}},\left(t_{i}\right)$, and the release rates of VOCs and $\mathrm{CO}_{2}$.

\subsubsection{Standard deviations of $J_{\mathrm{NO}}, k_{\mathrm{NO}}, P_{\mathrm{NO}}, U_{\mathrm{NO}}$, $\mathrm{m}_{\mathrm{NO}, \mathrm{comp}}, Q_{10 \_\mathrm{k}, \mathrm{NO}}$, and $Q_{10 \_\mathrm{P}, \mathrm{NO}}$}

To calculate $\sigma_{J, \mathrm{NO}}$, Eq. (1) is recalled (see Sect. 2):

$J_{\mathrm{NO}}=\frac{Q}{m_{\mathrm{soil}}}\left(m_{\mathrm{NO}, \mathrm{cham} 1,0}-m_{\mathrm{NO}, \text { in }}\right) f_{\mathrm{C}, \mathrm{NO}}$.

For application of the general Gaussian error propagation, the derivatives of $J_{\mathrm{NO}}$ with respect to $m_{\text {soil }}, Q, m_{\mathrm{NO} \text {,cham }}$, $m_{\mathrm{NO} \text {,in }}, f_{\mathrm{C}, \mathrm{NO}}$ as well as their standard deviations $\left(\sigma_{\mathrm{msoil}}\right.$, $\sigma_{Q}, \sigma_{\mathrm{mNOcham}}, \sigma_{m N \text { Oin }}$, and $\left.\sigma_{f, \mathrm{C} \mathrm{NO}}\right)$ have to be considered. However, it can be assumed that $\sigma_{f, \mathrm{C} \mathrm{NO}} \approx 0$, and experimental evidence has shown that both $\sigma_{\text {msoil }}$ and $\sigma_{Q}$ are negligible (less than $1 \%$ of $m_{\text {soil }}, Q$, respectively). Hence, the standard deviation of $J_{\mathrm{NO}}$ is given by

$\sigma_{\mathrm{J}, \mathrm{NO}}= \pm J_{\mathrm{NO}} \sqrt{\left(\frac{\sigma_{\mathrm{mNO} \text { cham }}}{m_{\mathrm{NO}, \mathrm{cham}}}\right)^{2}+\left(\frac{\sigma_{\mathrm{mNOin}}}{m_{\mathrm{MO}, \mathrm{in}}}\right)^{2}}$.

Analogously, according to Eqs. (12a), (14b), (13b), and (15b) only the derivatives of $m_{\mathrm{NO}}$,cham and $m_{\mathrm{NO}}$,in, as well as their standard deviations $\sigma_{\mathrm{mNOcham}}$ and $\sigma_{\mathrm{mNO}}$ in have to be considered for the calculation of the standard deviations of $k_{\mathrm{NO}}$ $\left(U_{\mathrm{NO}}\right), P_{\mathrm{NO}}$, and $m_{\mathrm{NO}, \mathrm{comp}}\left(=-P_{\mathrm{NO}} /\left(k_{\mathrm{NO}} f_{\mathrm{C}, \mathrm{NO}}\right)\right)$, which are given by 


$$
\begin{gathered}
\sigma_{\mathrm{k}, \mathrm{NO} \_\mathrm{T} 0}= \pm \frac{Q}{m_{\mathrm{soil}}\left(m_{\mathrm{NO}, \mathrm{cham} 2,0}-m_{\mathrm{NO}, \mathrm{cham} 1,0}\right)}\left[\sigma_{\mathrm{mNOin} 2}^{2}\right. \\
+\sigma_{\mathrm{mNOin} 1}^{2}+\left(\frac{m_{\mathrm{NO}, \mathrm{cham} 1,0}}{m_{\mathrm{NO}, \mathrm{cham} 2,0}-m_{\mathrm{NO}, \mathrm{cham} 1,0}}\right)^{2}\left(\sigma_{\mathrm{mNOcham} 2,0}^{2}\right. \\
\left.\left.+\sigma_{\mathrm{mNOcham} 1,0}^{2}\right)\right]^{\frac{1}{2}} \\
\sigma_{\mathrm{U}, \mathrm{NO} \_\mathrm{T} 0}= \pm U_{\mathrm{NO} \_\mathrm{T} 0}\left[\left(\frac{\sigma_{\mathrm{k}, \mathrm{NO} \_\mathrm{T} 0}}{k_{\mathrm{NO} \_\mathrm{T} 0}}\right)^{2}+\left(\frac{\sigma_{\mathrm{mNOcham} 1,0}}{m_{\mathrm{NO}, \mathrm{cham} 1,0}}\right)^{2}\right]^{\frac{1}{2}} \\
\sigma_{\mathrm{P}, \mathrm{NO} \_\mathrm{T} 0}= \pm P_{\mathrm{NO} \_\mathrm{T} 0}\left[\left(\frac{\sigma_{\mathrm{J}, \mathrm{NO} \_\mathrm{T} 0}}{J_{\mathrm{NO} \_\mathrm{T} 0}}\right)^{2}+\left(\frac{\sigma_{\mathrm{k}, \mathrm{NO} \_\mathrm{T} 0}}{k_{\mathrm{NO} \_\mathrm{T} 0}}\right)^{2}\right. \\
\left.+\left(\frac{\sigma_{\mathrm{mNOcham} 1,0}}{m_{\mathrm{NO}, \mathrm{cham} 1,0}}\right)^{2}\right]^{\frac{1}{2}} \\
\sigma_{\mathrm{mNOcomp} \_\mathrm{T} 0} m= \pm m_{\mathrm{NO}, \mathrm{comp} \_\mathrm{T} 0}\left[\left(\frac{\sigma_{\mathrm{k}, \mathrm{NO} \_\mathrm{T} 0}}{k_{\mathrm{NO} \_\mathrm{T} 0}}\right)^{2}\right. \\
\left.+\left(\frac{\sigma_{\mathrm{P}, \mathrm{NO} \_\mathrm{T} 0}}{P_{\mathrm{NO} \_\mathrm{T} 0}}\right)^{2}\right]^{\frac{1}{2}} \cdot
\end{gathered}
$$

For the standard deviations of $k_{\mathrm{NO}}, U_{\mathrm{NO}}, P_{\mathrm{NO}}$, and $m_{\mathrm{NO}, \text { comp }}$ at $T_{\text {soil }}=T_{1}\left(\sigma_{\mathrm{k}, \mathrm{NO} \mathrm{C}_{-} 1}, \sigma_{\mathrm{U}, \mathrm{NO} \_\mathrm{T} 1}, \sigma_{\mathrm{P}, \mathrm{NO} \_\mathrm{T} 1}\right.$, and $\left.\sigma_{\mathrm{m}, \text { NOcomp_T1 }}\right)$ the indices "1", " 2 ", and "T0" in Eqs. (2730 ) have to be replaced by "3", " 4 ", and "T1", respectively.

The $Q_{10}$ values of NO production and NO consumption are defined by

$$
\begin{aligned}
& Q_{10 \_\mathrm{P}, \mathrm{NO}}=\frac{P_{\mathrm{NO}}\left(\theta_{0}, T_{1}\right)}{P_{\mathrm{NO}}\left(\theta_{0}, T_{0}\right)} \text { and } \\
& Q_{10 \_\mathrm{U}, \mathrm{NO}}=\frac{U_{\mathrm{NO}}\left(\theta_{0}, T_{1}\right)}{U_{\mathrm{NO}}\left(\theta_{0}, T_{0}\right)}=\frac{k_{\mathrm{NO}}\left(\theta_{0}, T_{1}\right)}{k_{\mathrm{NO}}\left(\theta_{0}, T_{0}\right)},
\end{aligned}
$$

where $T_{1}=T_{0}+10$. Consequently, the standard deviations of $Q_{10 \_ \text {P,NO }}$ and $Q_{10 \_ \text {U,NO }}$ are given by

$\sigma_{\mathrm{Q} 10 \_\mathrm{PNO}}= \pm Q_{10 \_\mathrm{P}, \mathrm{NO}}\left[\left(\frac{\sigma_{\mathrm{P}, \mathrm{NO} \_\mathrm{T} 1}}{P_{\mathrm{NO} \_\mathrm{T} 1}}\right)^{2}+\left(\frac{\sigma_{\mathrm{P}, \mathrm{NO} \_\mathrm{T} 0}}{P_{\mathrm{NO} \_\mathrm{T} 0}}\right)^{2}\right]^{\frac{1}{2}}$

$\sigma_{\mathrm{Q} 10 \_\mathrm{UNO}}= \pm Q_{10 \_\mathrm{k}, \mathrm{NO}}\left[\left(\frac{\sigma_{\mathrm{k}, \mathrm{NO} \_\mathrm{T} 1}}{k_{\mathrm{NO} \_\mathrm{T} 1}}\right)^{2}+\left(\frac{\sigma_{\mathrm{k}, \mathrm{NO} \_\mathrm{T} 0}}{k_{\mathrm{NO} \_\mathrm{T} 0}}\right)^{2}\right]^{\frac{1}{2}}$.

\subsubsection{Standard deviations of the proportionality factor $g, m_{\text {soil }}\left(t_{i}\right)$, and $\theta_{\mathrm{g}},\left(t_{i}\right)$}

According to the definition of the proportionality factor $g$ (see Eq. (S6) and Eq. (S3.4), Sect. S.1 of the Supplement), the calculation of $\sigma_{\mathrm{g}}$ requires the derivatives of $g$ with respect to $m_{\text {soil }}\left(t_{0}\right), m_{\text {soil }}\left(t_{S}\right), V, s_{\mathrm{H}_{2} \mathrm{O} \text {, cham }}\left(t_{0}\right), s_{\mathrm{H}_{2} \mathrm{O} \text {,cham }}\left(t_{S}\right), Q$, and
$S_{0}$, as well as their standard deviations $\left(\sigma_{m s o i l(t 0)}, \sigma_{m s o i l(t S)}\right.$, $\sigma_{V}, \sigma_{\text {scham }(t 0)}, \sigma_{\text {scham }(t S)}, \sigma_{Q}$, and $\left.\sigma_{S 0}\right)$. Application of general Gaussian error propagation leads to

$$
\begin{aligned}
\sigma_{\mathrm{g}} & = \pm\left(\frac{\Delta m}{D^{2}}\right)\left[\left(\frac{D}{\Delta m}\right)^{2}\left(\sigma_{\mathrm{msoil}\left(t_{S}\right)}^{2}+\sigma_{\mathrm{msoil}\left(t_{0}\right)}^{2}\right)\right. \\
& \left.+V^{2}\left(\sigma_{\text {scham }\left(t_{S}\right)}^{2}+\sigma_{\text {scham }\left(t_{0}\right)}^{2}\right)+\sigma_{S_{0}}^{2}\right]^{\frac{1}{2}},
\end{aligned}
$$

where $D=V \Delta s+S_{0}, \Delta m=m_{\text {soil }}\left(t_{S}\right)-m_{\text {soil }}\left(t_{0}\right), \Delta s=$ $s_{\mathrm{H}_{2} \mathrm{O} \text {,cham }}\left(t_{S}\right)-s_{\mathrm{H}_{2} \mathrm{O} \text {,cham }}\left(t_{0}\right)$, and $\sigma_{S_{0}}$ the standard deviation of the integration constant $S_{0}$ (for details, see Sect. 2 of supplement).

Typical values for $\sigma_{m s o i l(t 0)}, \sigma_{m s o i l(t S)}, \sigma_{\text {scham }(t 0)}$, and $\sigma_{\text {scham }(t S)}$ are within $0.5 \%$ of $m_{\text {soil }}\left(t_{0}\right), m_{\text {soil }}\left(t_{S}\right), s_{\text {cham }}\left(t_{0}\right)$, and $s_{\text {cham }}\left(t_{S}\right)$. Consequently, the standard deviation $\sigma_{\mathrm{g}}$ of the proportionality factor $g$ is as small as $1 \%$ of $g$.

The standard deviation $\sigma_{\theta g(t i)}$ of the actual gravimetric soil water content $\theta_{\mathrm{g}}\left(t_{i}\right)$, defined by Eq. (S11) is given by

$\sigma_{\theta \mathrm{g}(\mathrm{ti})}= \pm\left[\left(\frac{\sigma_{\mathrm{msoil}\left(t_{i}\right)}}{m_{\text {soil }}\left(t_{S}\right)}\right)^{2}+\left(-\frac{m_{\text {soil }}\left(t_{i}\right)}{m_{\text {soil }}^{2}\left(t_{S}\right)} \sigma_{\mathrm{m} \text { soil }(\mathrm{tS})}\right)^{2}\right]^{\frac{1}{2}}$,

where $\sigma_{\mathrm{msoil}\left(t_{i}\right)}$ is the standard deviation derived for the actual total soil mass $m_{\text {soil }}\left(t_{i}\right)$ as shown in Sect. 2 of supplement.

\subsubsection{Standard deviations of the VOC and $\mathrm{CO}_{2}$ release rates}

The error for $\mathrm{C}_{2} \mathrm{H}_{4} \mathrm{O}$ and $\mathrm{C}_{3} \mathrm{H}_{6} \mathrm{O}$ was calculated as

$\sigma_{\mathrm{m}, \mathrm{VOC}}=\sqrt{\left(\frac{\left(\sigma_{\mathrm{m}, \mathrm{VOCham}}+\sigma_{\mathrm{m}, \mathrm{VOCin}}\right)}{\text { cnt }_{\text {cham }, \text { corr }}}\right)^{2}+\left(\frac{\sigma_{\mathrm{fcal}}}{f_{\text {cal }}}\right)^{2}}$,

where $\sigma_{\mathrm{m}, \mathrm{VOC} \text {,in }}$ and $\sigma_{\mathrm{m}, \mathrm{VOC} \text {,cham }}$ are the standard deviations (in counts) for the incoming and chamber's headspace measurements, respectively; cnt $_{\text {cham, cor }}$ are the corrected counts and $\sigma_{\text {fcal }}$ is the standard deviation of the calibration factor $f_{\text {cal }}$.

The release rate of $\mathrm{CO}_{2}$, measured under static mode conditions of the laboratory chamber system, is defined via Eq. (25). The errors of $m_{\text {soil }}, f_{\mathrm{C}, \mathrm{CO}_{2}}, t_{0}$, and $t_{1}$ are considered to be negligible. The relative error of the total volume $V^{*}$, determined by the standard gas addition technique, was calculated to $1.5 \%$. Consequently, the standard deviation $\sigma_{J, \mathrm{CO}_{2}}$ of the $\mathrm{CO}_{2}$ release rate is formulated as

$$
\begin{aligned}
\sigma_{\mathrm{J}, \mathrm{CO}_{2}} & = \pm \frac{f_{\mathrm{C}, \mathrm{CO}_{2}} V^{*}}{m_{\mathrm{soil}}\left(t_{1}-t_{0}\right)}\left[\left(\left(m_{\mathrm{CO}_{2}, \text { cham }}\left(t_{1}\right)\right.\right.\right. \\
& \left.\left.-m_{\mathrm{CO}_{2}, \text { cham }}\left(t_{0}\right)\right) \sigma_{V^{*}} / V^{*}\right)^{2}+\sigma_{\mathrm{mCO}_{2} \text { cham }, t_{1}}^{2} \\
& \left.+\sigma_{\mathrm{mCO}_{2} \text { cham }, t_{0}}^{2}\right]^{\frac{1}{2}} .
\end{aligned}
$$




\subsubsection{Detection limit, precision, and data rejection criteria}

The LOD of the NO mixing ratio could be evaluated during each drying-out experiment where the soil chambers have been flushed by zero air. The LOD is usually defined as the lowest mixing ratio level that can be determined to be statistically different from a measurement of zero air (e.g. MacDougall and Crummett, 1980). In this study, we define the LOD for NO measurements as three times that standard deviation which has been obtained through a statistically significant number (>100) of zero-air measurements. Depending of the actual conditions of the dilution unit and/or the $\mathrm{NO}_{\mathrm{x}}$ analyser, $\mathrm{LOD}_{\mathrm{NO}}$ usually varies between 0.07 and $0.130 \mathrm{ppb}$. Since the errors of the measurement of NO mixing ratio propagate through all quantities which are characterising net NO release from soil samples, we have chosen for this study $\mathrm{LOD}_{\mathrm{NO}}=0.15 \mathrm{ppb}$ for further conservative estimates of errors and (minimum) detectability.

For this study, release rates, consumption and production rates, as well as the determination of characteristic $Q_{10}$ values are exclusively derived from differences of mixing ratios (often (very) small), particularly between those measured in the incoming (the chamber's headspace). Hence, the quantification of the analysers' reproducibility (precision) is as important as that of LOD. In case of NO mixing ratio measurements, we define precision as the dimensionless ratio of the standard deviation $\left(\sigma_{\mathrm{mNO}}\right)$ and the corresponding mixing ratio $\left(m_{\mathrm{NO}}\right)$. Corresponding data have been obtained during (i) routine multipoint calibration exercises and (ii) every drying-out experiment where different $\mathrm{NO}$ mixing ratios have been used for flushing the soil chambers. For $m_{\mathrm{NO}}>50 \mathrm{ppb}$, the precision of the used $\mathrm{NO}_{\mathrm{x}}$ analyser is rather low $(<0.01)$; however, it is sharply increasing for $m_{\mathrm{NO}}<10 \mathrm{ppb}$ (see Fig. 8).

As mentioned above, mean NO mixing ratios of the incoming air as well as of each chamber's headspace have recorded every $30 \mathrm{~s}$ for a total of $240 \mathrm{~s}$, and only data of the last $90 \mathrm{~s}$ have been used for further evaluation. Only those NO mixing ratios measured in each chamber's headspace have been considered for further evaluation which have been found to exceed the detection limit of the NO analyser ( $0.15 \mathrm{ppb}$; see above). Remaining NO mixing ratios had to pass a simple statistical test to ensure consistency of the data. Instead of applying an outlier test, the combinations of corresponding differences have been calculated. Those data which exceeded $95 \%$ of the corresponding cumulative frequency distribution have been rejected. Then, the difference between NO mixing ratios of the incoming and each chamber's headspace air has been calculated for use in Eq. (1). Since these differences can be very small (particularly for high and very small $\theta_{\mathrm{g}}$ values, cf. Fig. 4), they had to pass a statistical standard test to ensure their significance ( $F$ test for standard deviations, and a subsequent $t$ test for averages). Only those data pairs whose difference was significant

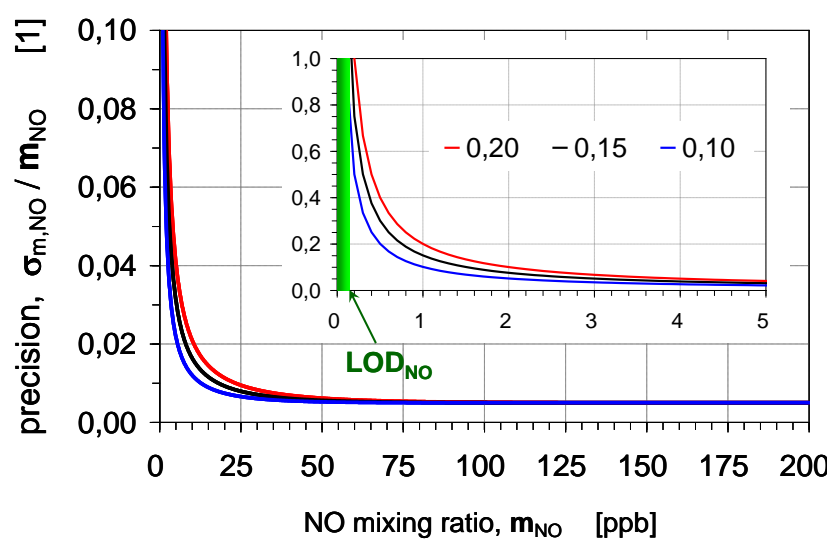

Figure 8. Precision of $\mathrm{NO}$ mixing ratios measured by the used $\mathrm{NO}_{\mathrm{x}}$ analyser. Data have been obtained (a) during routine multipoint calibration exercises, and (b) during each drying-out experiment using different $m_{\mathrm{NO}}$,in. Note $\mathrm{LOD}_{\mathrm{NO}}$ and the sharp of precision for $\mathrm{m}_{\mathrm{NO}}<10 \mathrm{ppb}$ as shown in the insert of Fig. 7.

( $p$ value 0.05 ) have been included in subsequent calculations. Consistency and significance of measured $\mathrm{H}_{2} \mathrm{O}$ signals (and respective differences) have been treated analogously.

\section{Results and discussion}

\subsection{Response of microbial activity to changing experimental conditions}

Knowledge of the microbial activity's response to temporal changes of soil moisture content, soil temperature, and incoming mixing ratios is important for any kind of incubation experiments. Wetted to the level of water-holding capacity and flushed with dry air, highly organic soils need between $48-96 \mathrm{~h}$ for dry out. For most dryland soils, only about $24 \mathrm{~h}$ are necessary to completely dry out the enclosed soil sample. However, with the new humidification facility (see Sect. 3), the drying-out period for these soils can easily be extended to $48-96 \mathrm{~h}$. Such periods are well comparable with those drying periods that occur naturally after rainfalls. With respect to changes of soil temperature, microbial activity's response is assumed to be quick. Using the NO compensation point mixing ratio (as an integral quantity for the combined action of production and consumption), Gödde and Conrad (1999) have already demonstrated that during a step-wise increase of soil temperature ( 4 to $45^{\circ} \mathrm{C} ; 5-10 \mathrm{~K}$ per $1-3 \mathrm{~h}$ ), the response of microbial activity is much less than $1 \mathrm{~h}$. This has guided the design of the heating/cooling facility of our improved laboratory dynamic chamber system. As described in the supplement, this facility needs about $30 \mathrm{~min}$ for the prescribed $10 \mathrm{~K}$ increase or decrease of soil temperature; another 10-15 min are allowed for final equilibration of the chamber system. Gödde and Conrad (1999) give no information concerning the microbial activity's response to changes of 
incoming NO mixing ratio. To examine that, first, the response time of the laboratory dynamic chamber system was determined. For repeated step-wise changes of incoming NO mixing ratios between 10 and ca. $30 \mathrm{ppb}, m_{\mathrm{NO} \text {, in }}$ data $(30 \mathrm{~s}$ means) were plotted versus the time elapsed after switching. From that, the $98 \%$ response time of the system $\left(\tau_{98}\right)$ has been determined to $113 \mathrm{~s}$. Since mean analyser signals were logged every $30 \mathrm{~s}$, it was decided for the measurement of $\mathrm{NO}\left(\mathrm{H}_{2} \mathrm{O}, \mathrm{VOC}\right)$ mixing ratio of incoming as well of every chamber's headspace air to discard the first $150 \mathrm{~s}$ and to keep the remaining $90 \mathrm{~s}$ ( 3 data points) for further evaluation (see Sect. 3). Consequently, each of the seven soil chambers of the laboratory system was probed for $4 \mathrm{~min}$; in any case, no significant temporal trends of $m_{\mathrm{NO}}$, cham have been observed after $150 \mathrm{~s}$ of probing each chamber. One entire cycle (i.e. probing all seven chambers at constant soil temperature, constant incoming NO mixing ratio, and "quasi-constant" gravimetric soil moisture content) lasted for $28 \mathrm{~min}$. Twenty different soil samples (including those studied in this work) were tested for potential trend of $J_{\mathrm{NO}}$; for that the cycle for all seven chambers was just repeated after switching $m_{\mathrm{NO}}$,in from zero air to $130 \mathrm{ppb}$. In any case, there was no significant difference between $m_{\mathrm{NO} \text {,cham }}$ data of the respective chamber measured in the first and in second cycle. From that it is concluded that microbial activity's response to step-changes of incoming NO mixing ratio might be as fast as for step-wise changes of soil temperature.

\subsection{Standardised procedure for initial wetting and sub-sample variability}

As described in Sect. 2, only four experiments (exp. 1-exp. 4) are necessary to completely characterise the net NO release from a soil sample in terms of gravimetric soil moisture content, soil temperature, and NO mixing ratio of the incoming air. However, former experiments have been performed on four individual sub-samples of the original soil sample, which led (i) to non-consistent values of $\theta_{0}$ and $\theta_{\mathrm{g}, 1}$, and (ii) to non-consistent, even contradicting net NO release rates under varying conditions of (prescribed) soil temperatures and incoming NO mixing ratios. Our decision to omit any pre-incubation of soil samples, but applying a simple standardised procedure for initial wetting of the soil samples (i.e. wetting up to corresponding water holding capacity) resulted in very uniform $\theta_{0}$ and $\theta_{\mathrm{g}, 1}$ values for conditions exp. 1exp. 4. It has to be emphasised that this is valid for a very wide range of optimum gravimetric soil moisture contents, namely from 0.02 (desert soil) to 2.12 (spruce covered forest soil). The second decision, namely to perform exp. 1-exp. 4 on only one (sub-)sample, has drastically reduced the effect of sub-sample variability with respect to non-consistent net NO release rates. This is best demonstrated by comparing the results of net NO release rates shown in Fig. 6 and those in Fig. 14. In both cases, sub-samples were from the same original soil sample of a hyper-arid desert soil of Mongolia. While the data in Fig. 6 result from a total of 12 sub-samples (three replicates using four sub-samples each), those in Fig. 14 were obtained for only two sub-samples. The overwhelming scatter of data points in Fig. 6 does not allow any meaningful conclusions about relations between net NO release rates, soil temperature, and incoming NO mixing ratio. In contrast, it is hard to distinguish each pair of data points in Fig. 14 which originate from two replicate studies under identical conditions of exp. 1-exp. 4 (i.e. each pair of circles and diamonds in Fig. 14). Moreover, there is a very clear picture how the net NO release rate for this hyper-arid soil depends on soil temperature. Since the reddish (exp. 3 and exp. 4) as well as the blueish (exp. 1 and exp. 2) fitted curves are statistically indistinguishable, there is evidence that in this hyper-arid soil sample NO consumption obviously does not occur. Potential microbial reasoning for this observation is discussed in detail below.

\subsection{Minimum detectable level of $J_{\mathrm{NO}}, k_{\mathrm{NO}}$, $Q_{10 \_ \text {U,NO}}, P_{\text {NOO }}$, and $Q_{10 \_P, N O}$}

For a given ratio of flushing rate $(Q)$ and dry mass of the enclosed soil sample ( $\left.m_{\text {soil,dry }}\right)$, the minimum detectable level of $J_{\mathrm{NO}}$ is dependent on the precision and the LOD of NO mixing ratio (see Eq. 1), because $J_{\mathrm{NO}}$ is defined as the difference of two measured, error prone NO mixing ratios. Minimum detectable levels have been estimated for the condition that $m_{\mathrm{NO} \text {,cham }}$ and $m_{\mathrm{NO} \text {,in }}$ in Eq. (1) must differ at least by the square root of the sum of their variances (squared standard deviations). In Fig. 9 the minimum detectable net NO release rate is shown as a function of the NO mixing ratio in the soil chamber's headspace $\left(m_{\mathrm{NO}}\right.$,cham $)$. At the $\mathrm{LOD}_{\mathrm{NO}}$ level of this study $(=0.15 \mathrm{ppb})$, the minimum detection level of $J_{\mathrm{NO}}$ is 0.34 and $0.08 \mathrm{ng} \mathrm{kg}^{-1} \mathrm{~s}^{-1}$ for $m_{\text {soil, dry }}=0.015 \mathrm{~kg}$ (EGER blueberry and spruce) and $0.06 \mathrm{~kg}$ (for the remainder of the soil samples), respectively. In earlier studies (e.g. Feig et al., 2008a; Gelfand et al., 2009; Bargsten et al., 2010), where $0.1 \mathrm{~kg}$ of dry soil mass has been used, the minimum detection level of $J_{\mathrm{NO}}$ (at $\mathrm{LOD}_{\mathrm{NO}}$ ) has been experimentally determined to 0.08 and $0.11 \mathrm{ng} \mathrm{kg}^{-1} \mathrm{~s}^{-1}$. For $m_{\text {soil, dry }},=0.1 \mathrm{~kg}$, our calculations would result in $0.08 \mathrm{ng} \mathrm{kg}^{-1} \mathrm{~s}^{-1}$.

Particularly on the minimum detectable level of $k_{\mathrm{NO}}$, and $Q_{10 \_k, N O}$, precision and LOD of NO mixing ratio measurements have a decisive impact, because these quantities are defined as difference of differences and as the ratio of differences of differences of NO mixing ratio, respectively. Respective minimum detectable levels have been estimated for the condition that (i) $J_{\mathrm{NO}}\left(\theta_{0}, T_{0}, m_{\mathrm{NO}, \text { cham }} 1_{1,0}\right)$ and $J_{\mathrm{NO}}\left(\theta_{0}\right.$, $\left.T_{0}, m_{\mathrm{NO}, \text { cham } \_2,0}\right)$ in Eqs. (12a) and (14b), and (ii) $k_{\mathrm{NO}}\left(\theta_{0}\right.$, $\left.T_{1}\right)$ and $k_{\mathrm{NO}}\left(\theta_{0}, T_{0}\right)$ in Eq.(7) must (significantly) differ at least by the square root of the sum of their variances (squared standard deviations). In Fig. 17, the minimum detectable level of the NO consumption rate coefficient $k_{\mathrm{NO}}$ is shown as function of that NO mixing ratio $\left(m_{\mathrm{NO} \text {, cham_1,0 }}\right)$, which will establish in the soil chamber for $m_{\mathrm{NO}, \text { in }_{-} 1} \approx 0 \mathrm{ppb}$, 


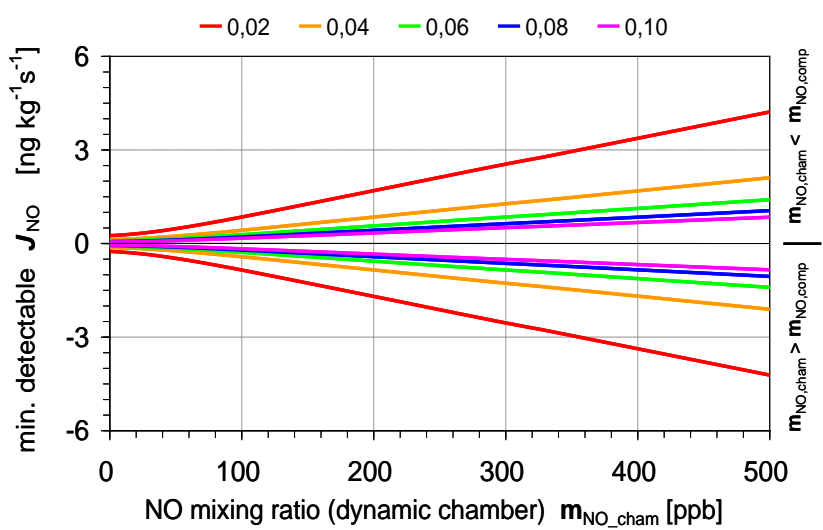

Figure 9. Minimum detectable net NO release rate as function of the NO mixing ratio in the soil chamber's headspace. Data have been calculated for $\mathrm{LOD}_{\mathrm{NO}}=0.15 \mathrm{ppb}$ on the basis of the $\mathrm{NO}_{\mathrm{x}}$ analyser's precision (see Fig. 8). Colour code indicates different values of dry mass of the enclosed soil ( $m_{\text {soil, dry, }}$ in $\mathrm{kg}$ ).

$\theta_{\mathrm{g}}=\theta_{0}$, and $T_{\text {soil }}=T_{0}$. According to Eq. (12a) and Fig. 1, $k_{\mathrm{NO}}$ is the slope of $J_{\mathrm{NO}}\left(\theta_{0}, T_{0}, m_{\mathrm{NO}}\right.$,cham $)$. Besides on the NO mixing ratio's precision, the minimum detectable level of $k_{\mathrm{NO}}$ depends decisively on the magnitude of the NO compensation point mixing ratio $m_{\mathrm{NO}}$,comp $\left(\right.$ where $J_{\mathrm{NO}}=0$ ). This is shown by the coloured curves (indicating different $\left.m_{\mathrm{NO}, \text { comp }}\right)$ in Fig. 17. With the present $\mathrm{NO}_{\mathrm{x}}$ analyser, minimum detectable levels of $k_{\mathrm{NO}}$ range between $-4 \times 10^{-7}$ and $-4 \times 10^{-6} \mathrm{~m}^{3} \mathrm{~kg}^{-1} \mathrm{~s}^{-1}$. This information is particularly important for arid and hyper-arid soils, where extremely low $k_{\mathrm{NO}}$ values have been found (e.g. Gelfand et al., 2009). In our study, values of $k_{\mathrm{NO}}\left(\theta_{0}, T_{0}\right)$ and $k_{\mathrm{NO}}\left(\theta_{0}, T_{1}\right)$ for the hyperarid desert soil are indeed exceeding respective minimum detectable levels of $k_{\mathrm{NO}}$, but due to their large standard deviations they are statistically not different from zero (s. Table 2). Consequently, for determination of corresponding NO compensation point mixing ratios of this soil, $P_{\mathrm{NO}}\left(\theta_{0}, T_{0}\right)$ and $P_{\mathrm{NO}}\left(\theta_{0}, T_{1}\right)$ have been divided by the minimum detectable $k_{\text {NO }}$ value $\left(=-4 \times 10^{-7} \mathrm{~m}^{3} \mathrm{~kg}^{-1} \mathrm{~s}^{-1}\right)$.

The minimum detectable level of $Q_{10 \_\mathrm{U}, \mathrm{NO}}$, as function of $m_{\mathrm{NO}, \text { cham }} 1,0$ and $m_{\mathrm{NO} \text {,comp }}$ is shown in Fig. 18. Data have been calculated for $\mathrm{LOD}_{\mathrm{NO}}=0.15 \mathrm{ppb}$ and the precision curve shown in Fig. 9. As an exponential increase of the NO consumption rate $U_{\mathrm{NO}}\left(=k_{\mathrm{NO}} \cdot m_{\mathrm{NO} \text {, cham }} \cdot f_{\mathrm{C}, \mathrm{NO}}\right)$ is assumed (see Sect. 2), $Q_{10 \_ \text {U,NO }}$ cannot fall below unity. With respect to the $\mathrm{NO}_{\mathrm{x}}$ analyser's precision, the $Q_{10 \_\mathrm{U}, \mathrm{NO}}$ value is the most error prone quantity, because six individual differences of NO mixing ratios have to be used for its calculation (see Eq. 16). Consequently, the minimum detectable level of $Q_{10 \_\mathrm{U}, \mathrm{NO}}$, strongly increases with increasing $m_{\mathrm{NO}, \mathrm{comp}}$ and decreasing headspace NO mixing ratio (particularly for $m_{\mathrm{NO}, \text { cham_1,0 }}<10 \mathrm{ppb}$ ). All calculated $Q_{10 \_\mathrm{U}, \mathrm{NO}}$ values of this study had to pass this minimum detectable $Q_{10 \_ \text {U,NO }}$ test. Data calculated for the "FINTHEN grassland" and
"KUCHE wheat" soil samples do not pass this criterion; in both cases the respective minimum detectable $Q_{10 \_\mathrm{U}, \mathrm{NO}}$ value has been used for further evaluation (1.366 and 1.278 , respectively; see Table 2).

Minimum detectable levels of $P_{\mathrm{NO}}\left(\theta_{0}, T_{0}\right)$ and $Q_{10} \mathrm{P}, \mathrm{NO}$ have also been calculated and have been proven to be only marginally dependent on the NO mixing ratio in the chamber's headspace (corresponding figures not shown). For $m_{\mathrm{NO}, \text { cham }}<60 \mathrm{ppb}, P_{\mathrm{NO}}\left(\theta_{0}, T_{0}\right)$ and $Q_{10 \_\mathrm{P}, \mathrm{NO}}$ are virtually

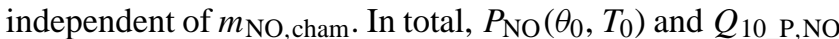
range between 0.4 and $1.6 \mathrm{ng} \mathrm{kg}^{-1} \mathrm{~s}^{-1}$ and 1.02 and 1.1 for $100<m_{\mathrm{NO}, \text { comp }}<500 \mathrm{ppb}$, respectively.

\subsection{NO release rates, $\mathrm{J}_{\mathrm{NO}}$, for five contrasting soils}

In contrast to earlier studies, only one soil sample has been exposed to conditions exp. 1-exp. 4 (see Sect. 2) during one drying-out experiment. Individual data of $m_{\mathrm{NO}}$,in, $m_{\mathrm{NO}, \text { cham }}, J_{\mathrm{NO}}\left(\theta_{0}, T_{0}, m_{\mathrm{NO}, \text { cham }}\right)$, and $J_{\mathrm{NO}}\left(\theta_{0}, T_{1}, m_{\mathrm{NO}, \text { cham }}\right)$ for exp. 1-exp. 4 are listed in Table 2. Results of net NO release rates from an arid, but agriculturally fertilised and irrigated wheatfield of Kucha (Kuche) oasis, northern Taklimakan desert (Uighur Autonomous Region Xinjiang, P.R. China) are shown in Fig. 10. Comparing Fig. 10 with Fig. 4 of Sect. 2, the results from this arid soil provide a textbookstyle illustration of the methodical concept described in Sect. 2. Net NO release rates observed for conditions exp. 1exp. 4 reveal a mean optimum value at $\theta_{0}=0.063 \pm 0.0026$; agreement of individual $\theta_{0}$ values is statistically highly significant. The same is valid for $\theta_{\mathrm{g}},{ }_{1}$, the second value to determine the gravimetric soil moisture's shape coefficient $\left(\theta_{\mathrm{g}, 1}=0.19 \pm 0.008\right.$ for $R_{J}=2$, see Eq. 8c). For this soil sample, it was not necessary to slow down the drying-out process by humidification of the incoming air. Hence the error of the incoming water-vapour signal $s_{\text {in }}$ was negligible. Only the error of the water-vapour signal $s_{\text {cham }}$ (measured in the chamber's headspace; see Sect. 3.5.2) contributed to the $\theta_{\mathrm{g}}$ error of all data points, which are very small (error bars of $\theta_{\mathrm{g}}$ in Fig. 10 are smaller than the size of symbols). Analogously, the same is valid for the $J_{\mathrm{NO}}$ error bars in Fig. 10 for conditions of exp. 1 and exp. 3 (i.e. $m_{\mathrm{NO} \text {,in_1 }}$, $\left.m_{\mathrm{NO}, \text { in_ } 1} \approx 0 \mathrm{ppb}\right)$. Only when $m_{\mathrm{NO}, \text { in_3 } 3}$ and $m_{\mathrm{NO}, \text { in_4 }}$ were around $137 \mathrm{ppb}$ (exp. 2 and exp. 4), the error of both mixing ratios $\left(m_{\mathrm{NO}}\right.$,in and $m_{\mathrm{NO} \text {, cham }}$; see Eq. 1$)$ contribute to a larger error of $J_{\mathrm{NO}}$. All NO net release rates for the arid soil sample are positive. As described in Sect. 2 (cf. Fig. 4), this is equivalent to the fact that the corresponding $\mathrm{NO}$ compensation point mixing ratio $m_{\mathrm{NO}}$,comp must be higher then $m_{\mathrm{NO}, \text { cham_3 } 3}$ and $m_{\mathrm{NO}, \text { cham_ } 4}$, respectively; indeed, $m_{\mathrm{NO}, \text { comp }}$ of this soil sample has been determined to $>500 \mathrm{ppb}$.

Net NO release rates from a soil sample which has been taken from the $\mathrm{O}$ horizon of an 80 year old spruce forest soil (Fichtel Mountains, SE Germany) are shown in Fig. 11. The understory of the sampling patch consisted of young spruce $(0.3-0.8 \mathrm{~m})$. A mean optimum value of $\theta_{0}=2.12( \pm 0.148)$ 
Table 2. Summary of results necessary to characterise NO consumption and NO consumption for the mid-latitude forest soils, mid-latitude grassland soil, and the arid and hyper-arid soils from Xinjiang and Mongolia used in this study. For the four experimental conditions exp. 1exp. 4 (see Sect. 2$)$, only those NO mixing ratios of the incoming $\left(m_{\mathrm{NO}}\right.$,in_x $)$ and chamber's headspace air $\left(m_{\mathrm{NO}, \text { cham_x }, 0}\right)$ are listed which have been observed at $\theta_{\mathrm{g}}=\theta_{0} . J_{\mathrm{NO}}$ data have been calculated with Eq. (1), $\bar{k}_{\mathrm{NO}}$ data with Eqs. (12b) and (14b), $P_{\mathrm{NO}}$ data with Eqs. (13b) and (15b), $Q_{10 \_U}\left(=Q_{10 \_k}\right)$ data with Eq. (16), and $Q_{10 \_} P$ data with Eq. (17). NO compensation point mixing ratios, $m_{\mathrm{NO}, \mathrm{comp}}$, are defined by the corresponding ratio of $P_{\mathrm{NO}}$ and $k_{\mathrm{NO}}$. The value $Q_{10 \_} J, \mathrm{mNO}$, in_ $1 / 3$ is defined by the ratio $J_{\mathrm{NO}}\left(\theta_{0}, T_{1}, m_{\mathrm{NO}, \text { cham }} 3,0\right): J_{\mathrm{NO}}\left(\theta_{0}, T_{0}\right.$, $m_{\mathrm{NO}, \text { cham_1,0). }}$.

\begin{tabular}{|c|c|c|c|c|c|c|c|c|c|c|c|}
\hline \multirow[b]{2}{*}{ Quantity } & \multicolumn{2}{|c|}{ EGER blueberry } & \multicolumn{2}{|c|}{ EGER spruce } & \multicolumn{2}{|c|}{ FINTHEN grassland } & \multicolumn{2}{|c|}{ KUCHE wheat } & \multicolumn{2}{|c|}{ MONGOLIA desert } & \multirow[b]{2}{*}{ unit } \\
\hline & avg & $\mathrm{SD}$ & avg & $\mathrm{SD}$ & avg & SD & avg & $\mathrm{SD}$ & avg & $\mathrm{SD}$ & \\
\hline exp.1: $m_{\mathrm{NO}, \text { cham_ } 1,0}$ & 1.5 & 0.15 & 13.2 & 0.17 & 3.0 & 0.15 & 17.5 & 0.18 & 4.1 & 0.15 & $\mathrm{ppb}$ \\
\hline $\exp .1: m_{N O, i n \_1}$ & 0.16 & 0.150 & 0.17 & 0.150 & 0.30 & 0.150 & 0.08 & 0.150 & 0.30 & 0.150 & ppb \\
\hline exp.2: $m_{\mathrm{NO}, \text { cham } \_2,0}$ & 459.7 & 2.30 & 478.8 & 2.39 & 128.9 & 0.65 & 148.9 & 0.75 & 133.2 & 0.67 & $\mathrm{ppb}$ \\
\hline $\exp .2: m_{\mathrm{NO}, \text { in_2 }}$ & 471.9 & 2.36 & 472.4 & 2.36 & 130.1 & 0.65 & 136.2 & 0.68 & 129.7 & 0.65 & $\mathrm{ppb}$ \\
\hline exp.3: $m_{\mathrm{NO}, \text { cham_ } 3,0}$ & 2.7 & 0.15 & 22.0 & 0.19 & 4.2 & 0.15 & 26.7 & 0.20 & 8.3 & 0.16 & $\mathrm{ppb}$ \\
\hline $\exp 3: 3: m_{N O, i n \_3}$ & 0.19 & 0.150 & 0.19 & 0.150 & 0.36 & 0.150 & 0.15 & 0.150 & 0.63 & 0.151 & ppb \\
\hline exp.4: $m_{\mathrm{NO}, \text { cham } 4,0}$ & 457.9 & 2.29 & 484.1 & 2.42 & 125.2 & 0.63 & 162.2 & 0.81 & 133.7 & 0.67 & $\mathrm{ppb}$ \\
\hline exp.4: $m_{\mathrm{NO}, \text { in } \_4}$ & 469.7 & 2.35 & 471.0 & 2.35 & 124.5 & 0.62 & 137.3 & 0.69 & 126.2 & 0.63 & $\mathrm{ppb}$ \\
\hline$J\left(\theta_{0}, T_{0}, m_{\mathrm{NO}, \text { cham } 1,0}\right)$ & 2.01 & 0.316 & 21.11 & 0.367 & 1.09 & 0.088 & 6.99 & 0.094 & 1.51 & 0.086 & $\mathrm{ng} \mathrm{kg}^{-1} \mathrm{~s}^{-1}$ \\
\hline$J\left(\theta_{0}, T_{0}, m_{\mathrm{NO}, \text { cham } \_2,0}\right)$ & -18.0 & 4.88 & 10.4 & 5.45 & -0.49 & 0.375 & 5.11 & 0.406 & 1.4 & 0.37 & $\mathrm{ng} \mathrm{kg}^{-1} \mathrm{~s}^{-1}$ \\
\hline$J\left(\theta_{0}, T_{1}, m_{\mathrm{NO}, \mathrm{cham} \_3,0}\right)$ & 3.66 & 0.318 & 35.28 & 0.392 & 1.58 & 0.088 & 10.7 & 0.101 & 3.07 & 0.088 & $\mathrm{ng} \mathrm{kg}^{-1} \mathrm{~s}^{-1}$ \\
\hline$J\left(\theta_{0}, T_{1}, m_{\mathrm{NO}, \text { cham } 4,0}\right)$ & -17.5 & 4.86 & 21.3 & 5.47 & $0.00^{\mathrm{a}}$ & 0.361 & 9.99 & 0.427 & 3.0 & 0.37 & $\mathrm{ng} \mathrm{kg}^{-1} \mathrm{~s}^{-1}$ \\
\hline$k\left(\theta_{0}, T_{0}\right) \times 10^{-5}$ & -7.642 & 1.865 & -4.032 & 2.049 & -2.192 & 0.5339 & -2.502 & 0.5539 & $-0.120^{\mathrm{b}}$ & $0.5188^{\mathrm{b}}$ & $\mathrm{m}^{3} \mathrm{~kg}^{-1} \mathrm{~s}^{-1}$ \\
\hline$k\left(\theta_{0}, T_{1}\right) \times 10^{-5}$ & -8.110 & 1.869 & -5.288 & 2.073 & -1.895 & 0.5371 & -0.852 & 0.5662 & $-0.091^{\mathrm{b}}$ & $0.5294^{\mathrm{b}}$ & $\mathrm{m}^{3} \mathrm{~kg}^{-1} \mathrm{~s}^{-1}$ \\
\hline$P\left(\theta_{0}, T_{0}\right)$ & 2.07 & 0.321 & 21.41 & 0.401 & 1.13 & 0.089 & 7.24 & 0.111 & 1.51 & 0.087 & $\mathrm{ng} \mathrm{kg}^{-1} \mathrm{~s}^{-1}$ \\
\hline$P\left(\theta_{0}, T_{1}\right)$ & 3.79 & 0.324 & 35.94 & 0.475 & 1.63 & 0.090 & 10.78 & 0.134 & 3.07 & 0.092 & $\mathrm{ng} \mathrm{kg}^{-1} \mathrm{~s}^{-1}$ \\
\hline$m_{\mathrm{NO}, \mathrm{comp}}\left(\theta_{0}, T_{0}\right)$ & 47 & 13.7 & 928 & 471.6 & 90 & 23.0 & 506 & 112 & $6590^{c}$ & - & $\mathrm{ppb}$ \\
\hline$m_{\mathrm{NO}, \mathrm{comp}}\left(\theta_{0}, T_{1}\right)$ & 82 & 20.0 & 1187 & 465.8 & 150 & 43.3 & 2211 & 1471 & $6590^{c}$ & - & $\mathrm{ppb}$ \\
\hline$Q_{10 \_\mathrm{U}}$ & $1.061^{\mathrm{d}}$ & 0.3562 & 1.311 & 0.8416 & $1.366^{\mathrm{e}}$ & - & $1.278^{\mathrm{e}}$ & - & n.d. & - & {$[1]$} \\
\hline$Q_{10 \_\mathrm{P}}$ & 1.826 & 0.3234 & 1.679 & 0.0385 & 1.443 & 0.1395 & 1.488 & 0.0293 & 2.034 & 0.1327 & {$[1]$} \\
\hline$Q_{10 \_\mathrm{J}, \mathrm{mNO}, \text { in_} \_1 / 3}$ & 1.825 & 0.3284 & 1.671 & 0.0345 & 1.450 & 0.1416 & 1.523 & 0.0250 & 2.035 & 0.1308 & {$[1]$} \\
\hline$\theta_{0}$ & 1.16 & 0.102 & 2.12 & 0.148 & 0.20 & 0.025 & 0.06 & 0.003 & 0.023 & 0.002 & {$[1]$} \\
\hline$\theta_{\mathrm{g}, 1}$ & 2.80 & 0.211 & 4.71 & 0.447 & 0.40 & 0.118 & 0.19 & 0.008 & 0.040 & 0.000 & [1] \\
\hline$R_{J}$ & 2.0 & - & 2.0 & - & 2.0 & - & 2.0 & - & 2.0 & - & [1] \\
\hline$a$ & 1.2907 & - & 1.6377 & - & 2.5339 & - & 0.7721 & - & 3.5559 & - & [1] \\
\hline
\end{tabular}

${ }^{a}$ Calculated value is lower than the corresponding minimum detectable $J_{\mathrm{NO}}$ value (see Fig. 9 ) and significantly not different from zero (see Fig. 12); consequently, $J_{\mathrm{NO}}=0$ is being assumed here

${ }^{\mathrm{b}}$ Calculated data are statistically not significantly different from zero. ${ }^{\mathrm{c}}$ Data have been calculated using the respective $P_{\mathrm{NO}}$ value and the respective minimum detectable $k_{\mathrm{NO}}$ value

$\left(=-4 \times 10^{-7} \mathrm{~m}^{3} \mathrm{~kg}^{-1} \mathrm{~s}^{-1}\right.$, see Fig. 17). ${ }^{\mathrm{d}}$ Data is just at the corresponding minimum detectable $Q_{10 \_} U$ level (see Fig. 18). ${ }^{\mathrm{e}}$ Data falls short of minimum detectable values and has been replaced by minimum detectable $Q_{10 \_ \text {U value. }}$

has been identified for all net NO release rates observed for conditions exp. 1-exp. 4 (highly significant agreement between individual $\theta_{0}$ values). The observed optimum gravimetric soil moisture, which exceed unity, are due to the high content of soil organic matter (indicated by total $\mathrm{C}$ content of $44 \%$, see Table 1) which has a strong capability to absorb water. The mean of individual $\theta_{g, 1}$ value is $4.71 \pm 0.447$ (for $R_{J}=2$ ); agreement between them is highly significant. For this forest soil sample, it was necessary to slow down the drying-out process by humidification of the incoming air (in order to yield enough data points for quasi-constant $\theta_{\mathrm{g}}$ conditions during each switching cycle between different temperatures and incoming mixing ratios, see Sect. 3). Hence both, the errors of $s_{\text {in }}$ and $s_{\text {cham }}$ contributed to the $\theta_{\mathrm{g}}$ error of all data points, which are considerably larger than those for the arid soil sample (see Fig. 10). This spruce covered forest soil revealed highest net NO release rates of all soils investigated in this study (21 and $35 \mathrm{ng} \mathrm{kg}^{-1} \mathrm{~s}^{-1}$ for $T_{\text {soil }}=20^{\circ} \mathrm{C}$ and $30^{\circ} \mathrm{C}$, respectively). As already mentioned for the arid soil sample, considerable $J_{\mathrm{NO}}$ errors in Fig. 11 are due to larger errors of (non-zero) NO mixing ratios measured in both, the incoming and the chamber's headspace air (see Sect. 3.5.4). As for the arid soil sample, all NO net release rates are positive. This means that $m_{\mathrm{NO} \text {,cham } \_3}$ as well as $m_{\mathrm{NO} \text {,cham } \_4}$ are lower than the corresponding NO compensation point mix-

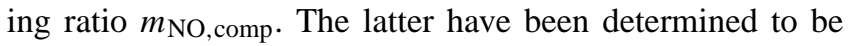
$928 \mathrm{ppb}\left(T_{\text {soil }}=20^{\circ} \mathrm{C}\right)$ and $1187 \mathrm{ppb}\left(T_{\text {soil }}=20^{\circ} \mathrm{C}\right)$, respectively.

Net NO release rates from a mid-latitude natural grassland, shown in Fig. 12, are in considerable contrast to those from the arid, but agriculturally managed soil from NW China. Net NO release rates from this grassland at Finthen (W Germany) are the lowest observed for all five soils investigated in this study. This is certainly due to the low nutrient status of this soil (see Table 1). For conditions exp. 1-exp. 4, individual values of optimum value of $\theta_{0}$ are statistically not different from each other, their mean is $\theta_{0}=0.20( \pm 0.025)$. The mean of $\theta_{\mathrm{g}, 1}$, however, reveals higher scatter $(0.40 \pm 0.118$ 
KUCHE, wheat covered arid soil (fertilized \& irrigated)

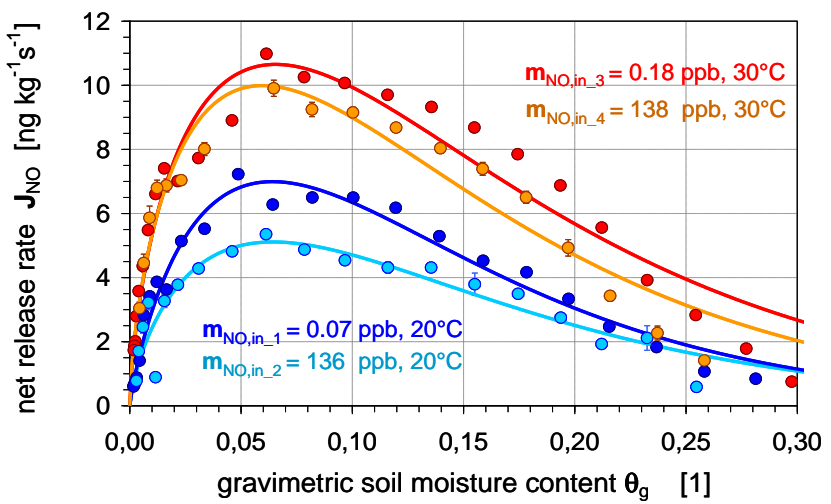

Figure 10. Net NO release rates of a sample taken from an arid, but agriculturally managed (fertilised and irrigated) wheat covered soil in southern Xinjiang, P. R. China. Measurements under the four conditions of exp. 1-exp. 4 (see Sect. 2) have been performed on one single soil sample; the colour code represents these four conditions.

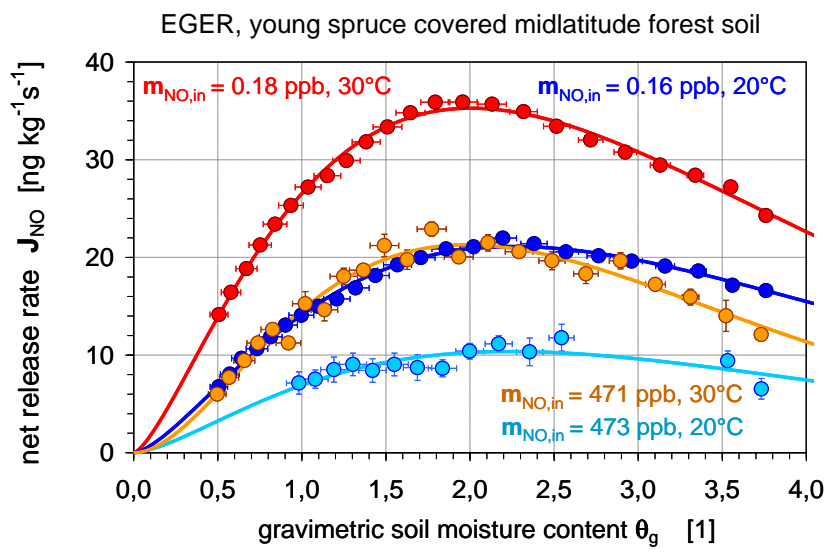

Figure 11. As Fig. 10, but for a sample taken from an organic-rich forest soil covered with young spruce (Fichtel Mountains, SE Germany).

for $R_{J}=2$, see Eq. 8c). Like for the spruce covered forest soil, it was necessary to slow down the drying-out process by humidification of the incoming air. Consequently, the $\theta_{\mathrm{g}}$ error of all data points is correspondingly larger. Net NO release rates observed for $m_{\mathrm{NO}, \text { in_ } 2}=131 \mathrm{ppb}\left(T_{\text {soil }}=20^{\circ} \mathrm{C}\right)$ are negative and very small (less than $-0.6 \mathrm{ng} \mathrm{kg}^{-1} \mathrm{~s}^{-1}$ ), but still exceeding the minimum detectable net $\mathrm{NO}$ release rate. Since they are negative, the corresponding NO compensation point mixing ratio $m_{\mathrm{NO}, \text { comp }}(90 \pm 23.0 \mathrm{ppb})$ is smaller than $m_{\mathrm{NO}, \text { cham } \_2}(129 \pm 0.6 \mathrm{ppb})$. For $m_{\mathrm{NO}, \text { in_4 }}=125 \mathrm{ppb}\left(T_{\mathrm{soil}}=\right.$ $30^{\circ} \mathrm{C}$ ), however, all data points are lower than the corresponding minimum detectable net $\mathrm{NO}$ release rate and they scatter around $J_{\mathrm{NO}}=0$. This is a logical consequence that $m_{\mathrm{NO}, \text { cham } \_4}(125 \pm 0.6 \mathrm{ppb})$ was close to the corresponding
FINTHEN, midlatitude natural grassland soil

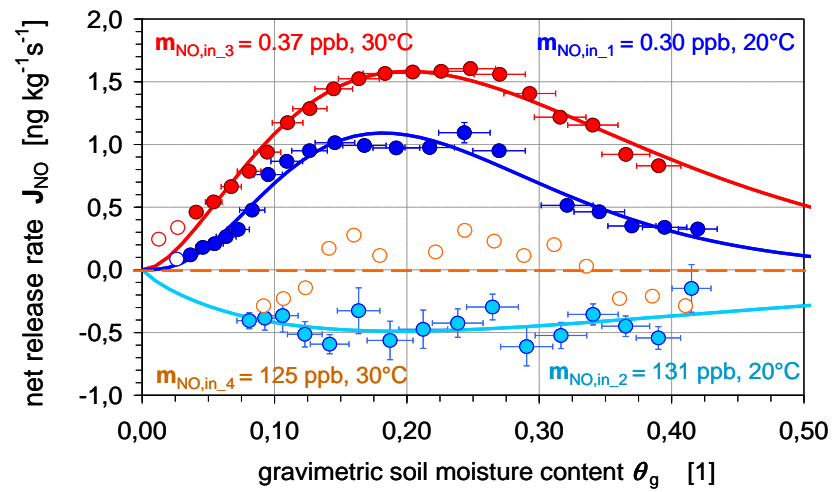

Figure 12. As Fig. 10, but for a sample taken from a grassland soil (Finthen, W Germany). Data points marked by empty circles fall within the "deadband" of non-detectable $J_{\mathrm{NO}}$ values (defined by \pm minimum detectable net NO release rate; see Sect. 4.2).

NO compensation point mixing ratio $m_{\mathrm{NO}}$,comp, which has been determined to be $150 \pm 43.3 \mathrm{ppb}$.

The soil sample from the blueberry covered forest soil has been taken close to that from the young spruce covered soil. Therefore, indicated by its high total $\mathrm{C}$ content (41\%, see Table 1), its soil organic matter content is also high and optimum gravimetric soil moisture content of this soil also exceed unity (see Fig. 13). The mean optimum gravimetric soil moisture content for conditions exp. 1-exp. 4 is $\theta_{0}=1.16( \pm 0.102)$, individual values are indistinguishable from each other on a highly significant level, which is also valid for corresponding $\theta_{\mathrm{g}, 1}$ values (mean $\theta_{\mathrm{g}, 1}=2.80 \pm 0.211$ for $\left.R_{J}=2\right)$. Whereas the net $\mathrm{NO}$ release rates of this sample are positive for $m_{\mathrm{NO}, \text { in_1 }}=0.17 \mathrm{ppb}\left(T_{\text {soil }}=20^{\circ} \mathrm{C}\right)$ and $m_{\mathrm{NO} \text {,in_3 }}=0.18 \mathrm{ppb}\left(T_{\text {soil }}=30^{\circ} \mathrm{C}\right)$, they are negative for $m_{\mathrm{NO}, \text { in } \_2}=470 \mathrm{ppb}\left(T_{\text {soil }}=20^{\circ} \mathrm{C}\right)$ and $m_{\mathrm{NO}, \text { in } \_4}=472 \mathrm{ppb}$ $\left(T_{\text {soil }}=30^{\circ} \mathrm{C}\right)$. Compared with the remainder of the soils in this study, the positive values are rather low (2.01 and $3.66 \mathrm{ng} \mathrm{kg}^{-1} \mathrm{~s}^{-1}$ ). Negative net NO release rates (obtained at ca. $470 \mathrm{ppb}$ of the incoming air), are as low as -17.5 and $-18.0 \mathrm{ng} \mathrm{kg}^{-1} \mathrm{~s}^{-1}$, respectively. Moreover, these net NO release rates are hardly distinguishable, despite the fact that they have been obtained at different soil temperatures.

Out of the five investigated soil samples, the one taken from the Gobi desert (Mongolia) is the most exotic one. The mean optimum gravimetric soil moisture content, $\theta_{0}$, for conditions exp. 1-exp. 4 is as low as $0.02( \pm 0.002)$, the mean $\theta_{\mathrm{g}, 1}$ value is 0.04 . Even at these very low $\theta_{\mathrm{g}}$ levels, individual $\theta_{0}$ and $\theta_{\mathrm{g}, 1}$ values are indistinguishable from each other on a highly significant level. Surprisingly, all net NO release rates from this hyper-arid soil (see Fig. 14) are higher than the values observed for the mid-latitude grassland soil (see Fig. 12). The most striking result, however, is that there is no significant difference between net NO release rates obtained for $T_{\text {soil }}=20^{\circ} \mathrm{C}$ and $T_{\text {soil }}=20^{\circ} \mathrm{C}$, neither for low $(0.27$ and 


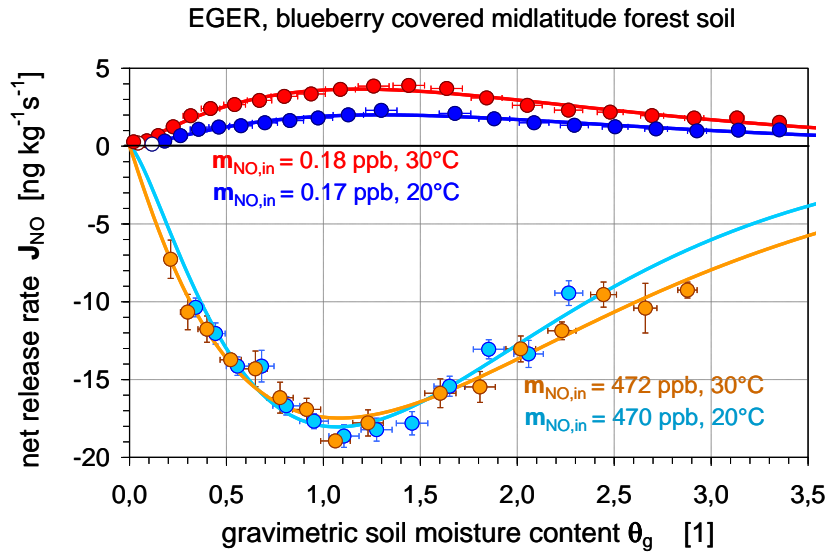

Figure 13. As Fig. 10, but for a sample taken from an organic-rich forest soil covered with blueberries (Fichtel Mountains, SE Germany). Data points marked by empty circles fall within the "deadband" of non-detectable $J_{\mathrm{NO}}$ values (defined by \pm minimum detectable net NO release rate; see Sect. 4.3).

$0.64 \mathrm{ppb})$ nor for high (133 and $134 \mathrm{ppb}) \mathrm{NO}$ mixing ratios of the incoming air.

\section{5 $\mathbf{P}_{\mathrm{NO}}, \mathrm{k}_{\mathrm{NO}}$, and $m_{\mathrm{NO}}$, comp for five contrasting soils}

In Table 2 , individual data of NO production rate $\left(P_{\mathrm{NO}}\right)$ and NO consumption rate coefficients $\left(k_{\mathrm{NO}}\right)$ are listed for conditions of respective optimum gravimetric soil moisture content $\left(\theta_{0}\right), T_{\text {soil }}=20^{\circ} \mathrm{C}$, and $T_{\text {soil }}=30^{\circ} \mathrm{C}$. Dependencies of $P_{\mathrm{NO}}$ and $k_{\mathrm{NO}}$ over the entire range of gravimetric soil moisture content are shown in Figs. 19 and 20, respectively. Double logarithmic scaling has to be chosen to illustrate the wide ranges of $P_{\mathrm{NO}}, k_{\mathrm{NO}}$, and $\theta_{\mathrm{g}}$, ( 2 orders of magnitude for each quantity), which have been observed in this study. This also demonstrates the obvious large contrast of microbial activities within these five soil samples. The wide range of observed $\theta_{\mathrm{g}}$ values is certainly due to the wide range of individual soil textures and soil organic matter, which in turn determine the water-holding capacity (i.e. sandy soils usually exhibit $\theta_{\mathrm{g}}$ values $\ll 1$, while organic-rich soils easily exceed unity; Bargsten et al., 2010; Wickland and Neff, 2008). However, the fact that the distribution of optimum gravimetric water content is quite similar (i.e. $\theta_{0}>1$ for the mid-latitude forest soils, $\theta_{0} \ll 1$ for the remainder of soil samples) may point to different microbial communities acting in these contrasting soils; different contribution of these communities to NO production and NO consumption might be due to microbial ecology which results in diverse microbial adaptation to prevailing field conditions, niche differentiation, and habitat preference. Considering the wide range of observed $k_{\mathrm{NO}}$ values for $T_{\text {soil }}=20^{\circ} \mathrm{C}$ (see Fig. 20), similar ecosystems seem to exhibit similar behaviour, i.e. KUCHE wheat and FINTHEN grassland versus EGER blueberry and "EGER spruce"; but this is obviously not the case if the maxima of

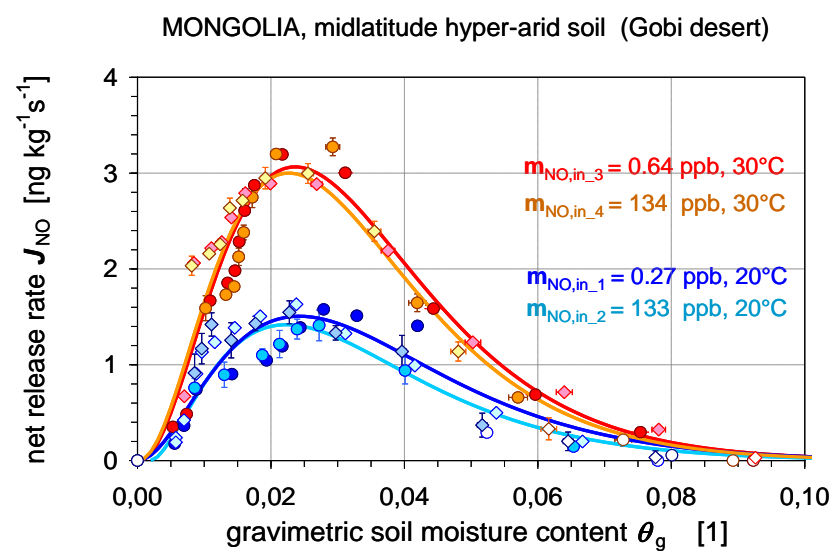

Figure 14. As Fig. 10, but for a sample taken from a hyper-arid soil in the Gobi desert, Mongolia. Data points originated from two replicate measurements (two different sub-samples) which are identified by corresponding circles and diamonds. Data points marked by empty circles and diamonds fall within the "deadband" of nondetectable values (defined by \pm minimum detectable net NO release rate).

$P_{\mathrm{NO}}$ at $T_{\text {soil }}=20^{\circ} \mathrm{C}$ are considered (see Fig. 19). However, the high maximum $P_{\mathrm{NO}}$ value of the arid wheat-field soil is certainly a result of agricultural management, which includes fertilisation and irrigation by flooding every 14 days in the growing season. Frequent flooding (i.e. water saturation of the soil), followed by nearly complete dry out (within a couple of days) should be considered to explain the relative large shape width of the $\theta_{\mathrm{g}}$ curve: soil microbial communities might be adapted to and being active within this wide range of $\theta_{\mathrm{g}}$. In Figs. 19 and 20, the response of $P_{\mathrm{NO}}$ and $k_{\mathrm{NO}}$ of all five soils to other soil temperatures $\left(10\right.$ and $\left.30{ }^{\circ} \mathrm{C}\right)$ is indicated by respective thinner lines. It should be noted that these curves are calculated according to Eq. (4) using $P_{\mathrm{NO}}\left(\theta_{0}\right.$, $\left.T_{0}\right)$ and $k_{\mathrm{NO}}\left(\theta_{0}, T_{0}\right)$ and those $Q_{10 \_\mathrm{P}, \mathrm{NO}}$ and $Q_{10 \_\mathrm{k}, \mathrm{NO}}$ values which are listed in Table $2\left(Q_{10 \_\mathrm{k}, \mathrm{NO}}=Q_{10 \_\mathrm{U}, \mathrm{NO}}\right.$; see Sect. 2). $Q_{10 \_U, N O}$ for FINTHEN grassland and KUCHE wheat represent data of lower detectable limit of $Q_{10 \_ \text {U,NO, }}$ rather than data from respective measurements. With increasing soil temperature all soils show corresponding increase in $P_{\mathrm{NO}}$ as well as in $k_{\mathrm{NO}}$. The hyper-arid desert soil from Mongolia exhibits by far the largest temperature response: the relative increase of $P_{\mathrm{NO}}\left(\theta_{0}, T_{\text {soil }}=20^{\circ} \mathrm{C}\right)$ to $P_{\mathrm{NO}}\left(\theta_{0}\right.$, $T_{\text {soil }}=30^{\circ} \mathrm{C}$ ) exceeds $200 \%$ (note, there are no corresponding $k_{\mathrm{NO}}$-curves in Fig. 20 , since the respective $Q_{10 \_\mathrm{U}, \mathrm{NO}}$ value could not be calculated due to non-significant $k_{\mathrm{NO}}\left(\theta_{0}\right.$, $\left.T_{0}\right)$ and $k_{\mathrm{NO}}\left(\theta_{0}, T_{1}\right)$-data). There is also a remarkable temperature response of the NO consumption rate coefficient for the KUCHE wheat soil. Observed $P_{\mathrm{NO}}$ and $k_{\mathrm{NO}}$ values are considered with respect to the soil property data given in Table 1. Both mid-latitude forest soils (EGER spruce and EGER blueberry) are characterised by high $\mathrm{CO}_{2}$ release rates suggesting the dominance of heterotrophic processes. High 
KUCHE, corn covered arid soil (fertilized \& irrigated)

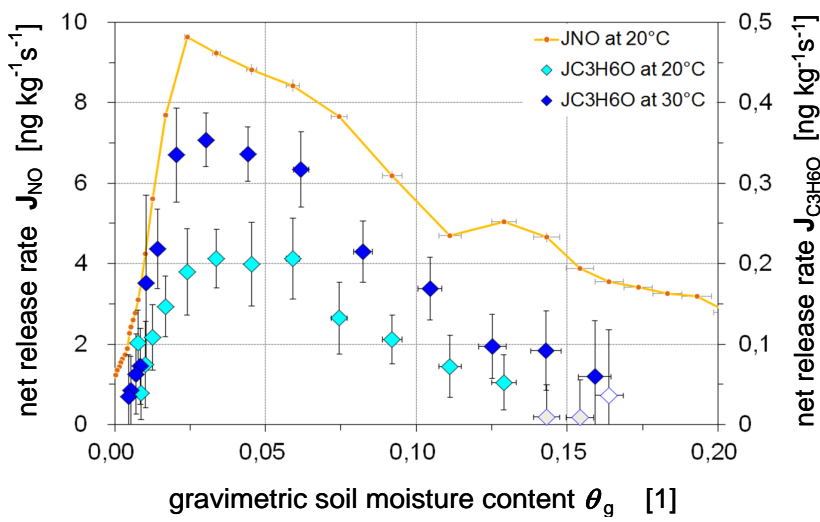

Figure 15. Net NO release rate $\left(T_{\text {soil }}=20^{\circ} \mathrm{C}\right)$ and net acetaldehyde $\left(\mathrm{C}_{3} \mathrm{H}_{6} \mathrm{O}\right)$ release rates $\left(T_{\text {soil }}=20^{\circ} \mathrm{C}\right.$ and $\left.30^{\circ} \mathrm{C}\right)$ at fumigation with zero air of a sample taken from an arid, but agriculturally managed (fertilised and irrigated) corn covered soil in southern Xinjiang, P. R. China. Data points marked by empty diamonds fall within the "deadband" of non-detectable values. Note that net NO release rates are expressed in terms of mass of nitrogen $(\mathrm{N})$, while those of $\mathrm{C}_{3} \mathrm{H}_{6} \mathrm{O}$ in terms of mass of carbon (C).

ammonium and nitrate contents of EGER spruce suggest that heterotrophic nitrification might be the relevant process for the observed higher $P_{\mathrm{NO}}$ rates in that soil, while comparatively lower ammonium and nitrate contents (ca. fourand twofold, respectively) point to heterotrophic denitrification in the EGER blueberry soil. However, it should be noted that potentially a small-scale difference in soil $\mathrm{N}$ mineral content might explain the observed large discrepancy in

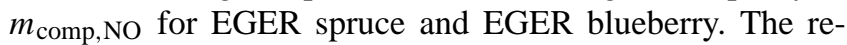
markably high ammonium and nitrate contents in both midlatitude soils are due to (i) high ability of organic matter constituents to absorb these nutrients, and (ii) very large $\mathrm{NH}_{4}^{+}$ and $\mathrm{NO}_{3}^{-}$inputs to this ecosystem by atmospheric $\mathrm{N}$ deposition (Wolff et al., 2010). Due to low nitrate $\left(2.2 \mathrm{mg} \mathrm{kg}^{-1}\right.$ ) content heterotrophic denitrification seems to prevail also in the FINTHEN grassland soil. In the arid and hyper-arid soils (KUCHE wheat and MONGOLIA desert) autotrophic nitrification might be the dominating process for NO production, since these soils are obviously ammonium limited, enriched in nitrate, low in total carbon, and both experience most of the time very low soil moisture. Both mid-latitude forest soils exhibit very low $\mathrm{pH}$ (ca. 3). Under these acidic conditions the activity of bacteria is usually limited and the activity of archaea (Gubry-Rangin et al., 2010) and fungi (Pennanen et al., 1998) dominates. Therefore, it might be possible that codenitrification of fungi, as found in an earlier study (Kumon et al., 2002), might be of relevance for NO emission from these soils. However, whether NO is produced and/or consumed by this process needs still further investigation.

In this study, NO compensation point mixing ratios were found to be dependent on soil temperature, but not on soil
KUCHE, wheat covered arid soil (fertilized \& irrigated)

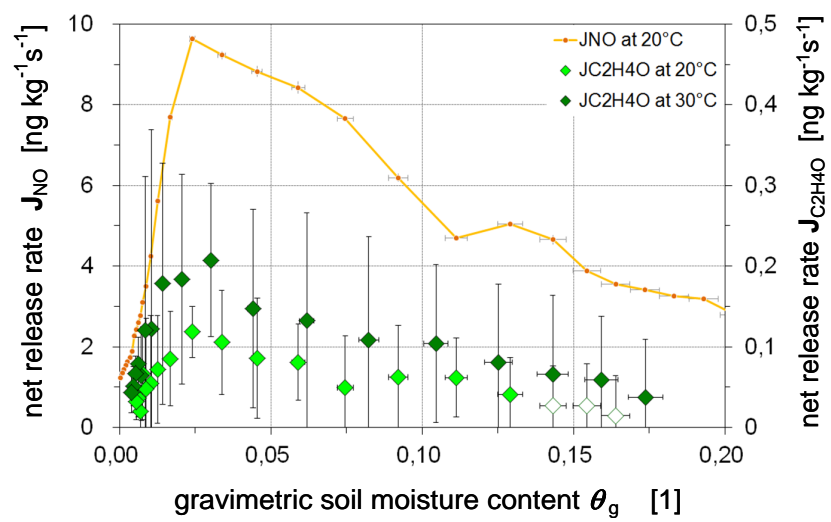

Figure 16. Net NO release rate $\left(T_{\text {soil }}=20^{\circ} \mathrm{C}\right)$ and net acetone $\left(\mathrm{C}_{2} \mathrm{H}_{4} \mathrm{O}\right)$ release rates $\left(T_{\text {soil }}=20^{\circ} \mathrm{C}\right.$ and $\left.30^{\circ} \mathrm{C}\right)$ at fumigation with zero air of a sample taken from an arid, but agriculturally managed (fertilised and irrigated) corn covered soil in southern Xinjiang, P. R. China. Data points marked by empty diamonds fall within the "deadband" of non-detectable values. Note that net NO release rates are expressed in terms of mass of nitrogen $(\mathrm{N})$, while those of $\mathrm{C}_{3} \mathrm{H}_{6} \mathrm{O}$ in terms of mass of carbon (C).

moisture (s. Table 2). Among all quantities characterising biogenic NO release, $m_{\mathrm{NO}}$,comp values cover the widest range (from $47 \mathrm{ppb}$ to $>6000 \mathrm{ppb}$ ). For the mid-latitude forest soils (EGER blueberry and EGER spruce) corresponding $m_{\mathrm{NO}, \text { comp }}$ values are $47 \pm 13.7$ and $928 \pm 472 \mathrm{ppb}\left(T_{\text {soil }}=\right.$ $\left.20^{\circ} \mathrm{C}\right)$, and $82 \pm 20$ and $1187 \pm 466 \mathrm{ppb}\left(T_{\text {soil }}=30^{\circ} \mathrm{C}\right)$, respectively. This is contrasting $m_{\mathrm{NO}, \mathrm{comp}}=380 \mathrm{ppb}$ (blueberry) and $m_{\mathrm{NO}, \text { comp }}=510 \mathrm{ppb}$ (spruce) which have been reported by Bargsten et al. (2010) for the same ecosystem $\left(T_{\text {soil }}=10^{\circ} \mathrm{C}, \theta_{\mathrm{g}}=1\right)$. Since Bargsten et al. (2010) observed only very weak relationships to soil properties, the potential of ectomycorrhiza as a major contributor to NO production has been suspected. However, since (i) soil samples of this study as well as by Bargsten et al. (2010) have been taken on very small spatial scales (within some tens of metres), and (ii) ectomycorrhiza is found in symbiosis with both, the roots of spruce and blueberries, it is unlikely that ectomycorrhiza should entirely explain the large differences of $m_{\mathrm{NO} \text {,comp }}$ found in both studies. However, the data of Bargsten et al. (2010) have been observed by a former version of the laboratory dynamic chamber system, initial non-standardised wetting of soil samples, $\geq 3 \mathrm{~h}$ preincubation, and performing exp. 1-exp. 4 with four individual sub-samples each. NO compensation point mixing ratios for FINTHEN grassland, classified as steppe-like grassland, are $90 \pm 23 \mathrm{ppb}\left(T_{\text {soil }}=20^{\circ} \mathrm{C}\right)$ and $150 \pm 43 \mathrm{ppb}\left(T_{\text {soil }}=\right.$ $\left.30^{\circ} \mathrm{C}\right)$. This is in agreement with $m_{\mathrm{NO} \text {,comp }}=157 \pm 16 \mathrm{ppb}$ for the savannah grassland ecosystem of Nylsvley (Otter et al., 1990). For $T_{\text {soil }}=20^{\circ} \mathrm{C}$, NO compensation point mixing ratio for KUCHE wheat, an arid agriculturally managed soil, is $506 \pm 112 \mathrm{ppb}$ and very close to $m_{\mathrm{NO}, \text { comp }}=600 \mathrm{ppb}$ 


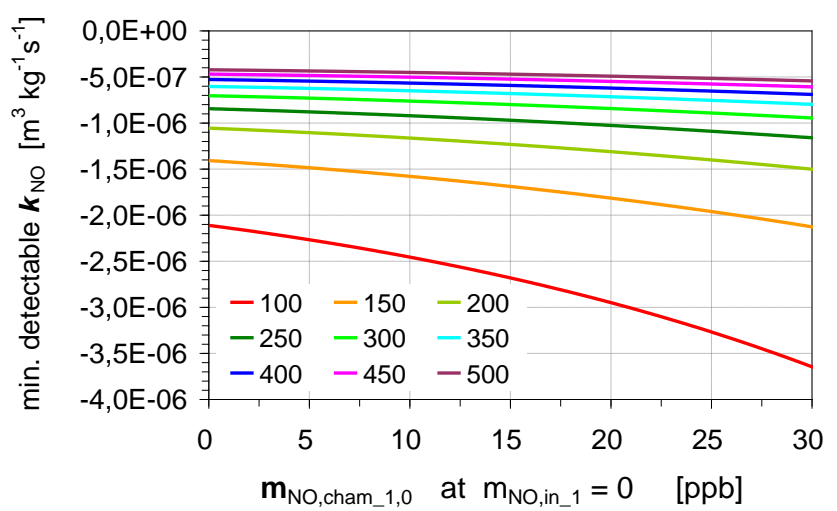

Figure 17. Minimum detectable NO consumption coefficient (at $\theta_{0}$ and $T_{0}$ ) as function of the NO mixing ratio in the soil chamber's headspace $\left(\theta_{\mathrm{g}}=\theta_{0} ; m_{\mathrm{NO}}\right.$,in_1/3 $\left.=0\right)$. Data have been calculated for $m_{\text {soil, dry }}=0.06 \mathrm{~kg}$ and $\mathrm{LOD}_{\mathrm{NO}}=0.15 \mathrm{ppb}$ on the basis of the $\mathrm{NO}_{\mathrm{X}}$-analyser's precision. Colour code indicates different $\mathrm{NO}$ compensation point mixing ratios, $m_{\mathrm{NO}}$, comp.

$\left(20^{\circ} \mathrm{C}\right)$ which has been reported for a dryland farming soil in Egypt by Saad and Conrad (1993). However, in this study a decrease of the NO compensation point mixing ratio from 20 to $30^{\circ} \mathrm{C}$ has been observed, which could not be confirmed by our study (because corresponding $Q_{10}$ data fall short of the minimum detectable value for $Q_{10 \_\mathrm{U}, \mathrm{NO}}$; see Table 2 ). Since the calculated $k_{\mathrm{NO}}$ values of the hyper-arid Mongolian desert soil have been found to be statistically indistinguishable from zero, corresponding $m_{\mathrm{NO}}$,comp $(6590 \mathrm{ppb})$ has been derived using the minimum detectable $k_{\mathrm{NO}}$ value instead (see Table 2). This is in great contrast to $m_{\mathrm{NO} \text {,comp }}<100 \mathrm{ppb}$ for soils from the Namib, Kalahari, and Sahara deserts reported by Feig (2009). However, also these data have been observed by a former version of the laboratory dynamic chamber system, initial non-standardised wetting of soil samples, $48 \mathrm{~h}$ pre-incubation, and performing exp. 1-exp. 4 with four individual sub-samples each. As already mentioned, the NO compensation point mixing ratio is defined by $m_{\mathrm{NO} \text {,comp }}=$ $f_{\mathrm{C}, \mathrm{NO}}^{-1} P_{\mathrm{NO}}\left(\theta_{\mathrm{g}}, T_{\text {soil }}\right) / k_{\mathrm{NO}}\left(\theta_{\mathrm{g}}, T_{\text {soil }}\right)$. Since both, NO production and NO consumption exhibit the same shapes of optimum curves with respect to $\theta_{\mathrm{g}}$ (see Sect. 2), $m_{\mathrm{NO} \text {,comp is a }}$ sole function of soil temperature, but only if $P_{\mathrm{NO}}$ and $k_{\mathrm{NO}}$ will own different dependencies on soil temperature. According to Eqs. (4) and (5) this is equivalent that $Q_{10 \_ \text {P,NO }}$ and $Q_{10 \_\mathrm{U}, \mathrm{NO}}\left(=Q_{10 \_\mathrm{k}, \mathrm{NO}}\right)$ must be different. For the two midlatitude forest soils, the dependency of $m_{\mathrm{NO}}$,comp on soil temperature is shown in Fig. 21 for the soil temperature range $10-35^{\circ} \mathrm{C}$. NO compensation point mixing ratios of EGER spruce are 10-fold higher than those from EGER blueberry; however, the increase of $m_{\mathrm{NO}}$,comp from $T_{\text {soil }}=10^{\circ} \mathrm{C}$ to $T_{\text {soil }}=35^{\circ} \mathrm{C}$ is fourfold for EGER blueberry and only about twofold for EGER spruce. Up to now, increasing NO compensation point mixing ratios with increasing soil temperature has only been reported by Gödde and Conrad (1999).

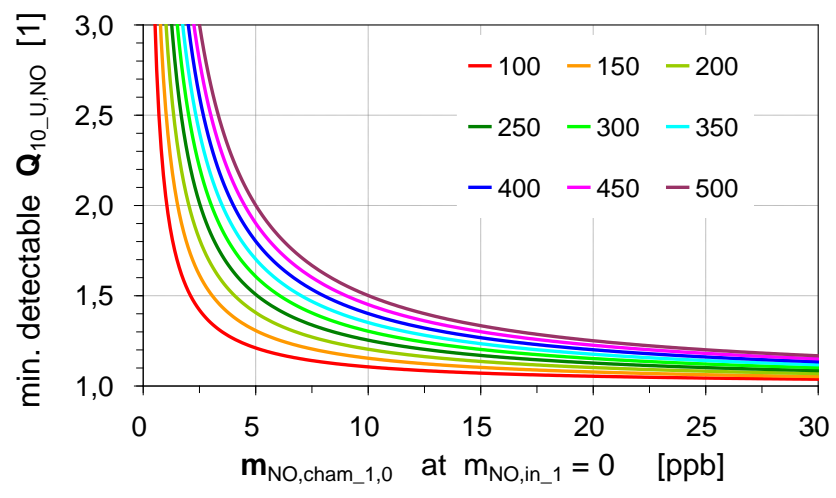

Figure 18. Minimum detectable $Q_{10}$ value of NO consumption rate $U_{\mathrm{NO}}$ as function of the NO mixing ratio in the soil chamber's headspace $\left(\theta_{\mathrm{g}}=\theta_{0} ; m_{\mathrm{NO}, \text { in_1/3 }}=0\right)$. Data have been calculated for $m_{\text {soil, dry }}=0.06 \mathrm{~kg}$ and LOD $\mathrm{NO}=0.15 \mathrm{ppb}, T_{0}=20^{\circ} \mathrm{C}$, and $T_{1}=30^{\circ} \mathrm{C}$ on the basis of the $\mathrm{NO}_{\mathrm{x}}$ analyser's precision (see Fig. 8). Colour code indicates different NO compensation point mixing ratios, $m_{\mathrm{NO}, \mathrm{comp}}$.

Moreover, for two mid-latitude soil samples (grassland and arable land), they have shown that with increasing soil temperature the ratio of nitrifiers to denitrifiers (both contributing to the net release of NO) was decreasing. High $m_{\mathrm{NO}}$,comp values of KUCHE wheat and MONGOLIA desert soils are characterological low in total carbon, high in nitrate, and are fast drying-out under field conditions. Since these factors hinder the development of anaerobic conditions, denitrification might be limited in these soils. That is confirmed by a very recent study of Orlando et al. (2012), who found a very low abundance of nirS-type denitrifiers and lack of denitrification activity for a desert soil from Atacama Desert, Chile. Due to very low ammonium and organic $\mathrm{C}$ contents, limited NO production within those soils is most likely by autotrophic nitrification. Compared to EGER spruce, the nitrate content of the EGER blueberry sample is lower and its $m_{\mathrm{NO}}$,comp value is comparable with that of the FINTHEN grassland soil, which has a low nitrate content, too. Therefore, it is suggested that even small differences of $\mathrm{pH}$ and total carbon of the EGER blueberry soil, compared with the EGER spruce soil, might promote denitrification by fungi in EGER blueberry, which results in a considerable low $m_{\mathrm{NO} \text {,comp value. }}$ The $\mathrm{pH}$ value of the FINTHEN grassland soil is 6.2 ; most likely, the activity of denitrifying bacteria might cause its low $m_{\mathrm{NO}}$,comp value. Already Pennanen et al. (1998) have shown that $\mathrm{pH}$ is an important factor that controls the activity of bacteria and fungi. More than two decades ago, Saad and Conrad (1993) investigated the temperature dependence of both, NO production and NO consumption. However, the results have shown a rather inconsistent pattern, namely either an optimum response (about $25-30^{\circ} \mathrm{C}$ ) or a continuous increase with soil temperature for $P_{\mathrm{NO}}$ and $k_{\mathrm{NO}}$, which led to complex responses of $m_{\mathrm{NO}}$ comp to soil temperature. Gödde and Conrad (1999), however, assumed that nitrifiers 


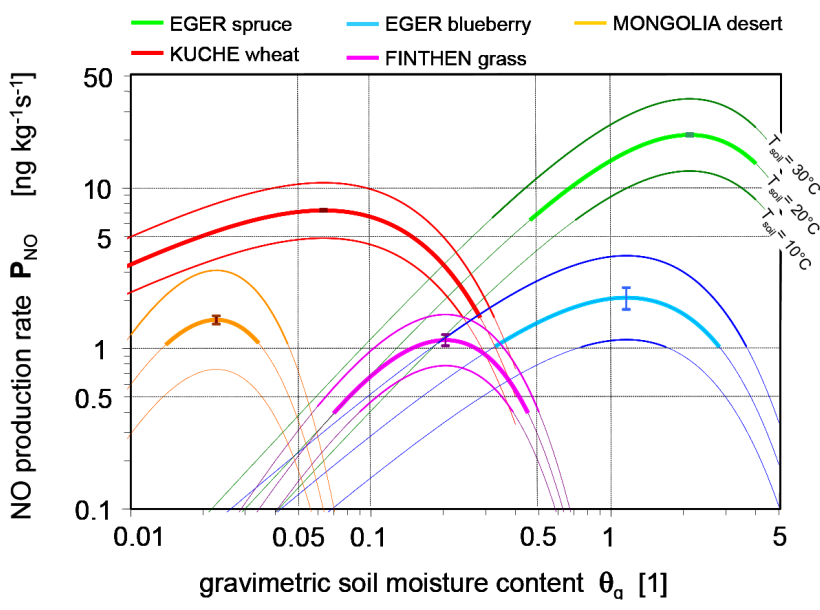

Figure 19. Summary of NO production rate $\left(P_{\mathrm{NO}}\right)$ results of the five soil samples in this study. The curves have been calculated using the $P_{\mathrm{NO}}\left(\theta_{0}, T_{0}\right), \theta_{0}, \theta_{\mathrm{g}, 1}$, and $Q_{10 \_\mathrm{P}, \mathrm{NO}}$ data listed in Table 2 . Thick solid lines represent conditions at $T_{\text {soil }}=20^{\circ} \mathrm{C}$, thinner solid lines above and below conditions of $T_{\text {soil }}=10^{\circ} \mathrm{C}$ and $T_{\text {soil }}=30^{\circ} \mathrm{C}$, respectively. Solid lines cover the range of those values which have passed corresponding rejection criterion $(=$ minimum detectable $P_{\mathrm{NO}}$, see Sect. 5.2). Error bars of $P_{\mathrm{NO}}\left(\theta_{0}, T_{0}\right)$ are from Table 2 and indicate respective optimum gravimetric soil moisture contents $\left(\theta_{0}\right)$.

and denitrifiers differ in their ability to adapt to different temperatures within different soils and with different incubation conditions. It is well known that nitrifiers and denitrifiers use different enzymes to produce and consume NO (Braker and Conrad, 2011). Since the enzymes of nitrifiers and denitrifiers differ in their $K_{\mathrm{m}}$ and $V_{\max }$ values (Koper et al., 2010; Betlach and Tiedje, 1981) and thereby in their efficiency, it seems reasonable to assume that both processes, NO production and consumption, show different response to changing soil temperatures. As mentioned at the beginning of this section, the amount of errors of measured NO mixing ratio is entirely due to the precision of our $\mathrm{NO}_{\mathrm{x}}$ analyser. Since six individual differences of NO mixing ratios have to be used for the calculation of $Q_{10 \_ \text {U,NO }}$ (see Eq. 16), this quantity is the most error prone and propagation of $\mathrm{NO}$ mixing ratio errors generates considerably large errors of $Q_{10 \_ \text {U,NO, which in }}$ turn determine the minimum detectable value of $Q_{10 \_ \text {U,NO. }}$. Only the $Q_{10}$ U,NO values of the EGER blueberry and EGER spruce soil samples passed this criterion.

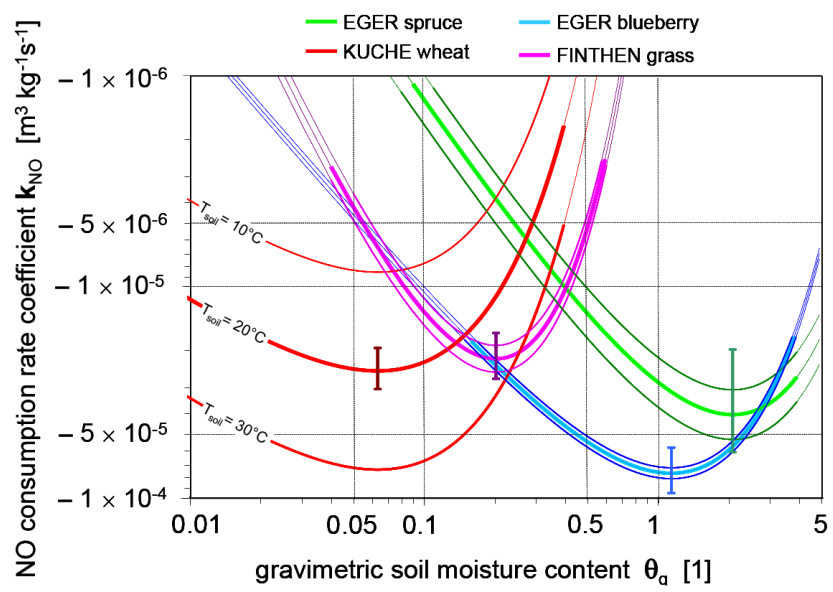

Figure 20. Summary of NO consumption rate coefficient $\left(k_{\mathrm{NO}}\right)$ results of the five soil samples in this study. The curves have been calculated using the $k_{\mathrm{NO}}\left(\theta_{0}, T_{0}\right), \theta_{0}, \theta_{\mathrm{g}, 1}$, and $Q_{10 \_\mathrm{U}, \mathrm{NO}}$ data listed in Table 2. Thick solid lines represent conditions at $T_{\text {soil }}=20^{\circ} \mathrm{C}$, thinner solid lines above and below conditions of $T_{\text {soil }}=10^{\circ} \mathrm{C}$ and $T_{\text {soil }}=30^{\circ} \mathrm{C}$, respectively. Solid lines cover the range of those values which have passed corresponding rejection criterion $(=\mathrm{min}-$ imum detectable $k_{\mathrm{NO}}$, see Sect. 5.2). Error bars of $k_{\mathrm{NO}}\left(\theta_{0}, T_{0}\right)$ are from Table 2 and indicate respective optimum gravimetric soil moisture contents $\left(\theta_{0}\right)$. Note that there is no $k_{\mathrm{NO}}$ curve for "MONGOLIA desert" soil, since the respective $Q_{10}$ U,NO value could not be calculated due to non-significant $k_{\mathrm{NO}}\left(\theta_{0}, T_{0}\right)$ and $k_{\mathrm{NO}}\left(\theta_{0}, T_{1}\right)$ data, see Table 2).

\subsection{NO production rate $\left(\boldsymbol{P}_{\mathrm{NO}}\right)$ versus NO consumption rate $\left(U_{\mathrm{NO}}\right)$}

As mentioned in Sect. 2, the net release of NO is the result of simultaneous NO production and $\mathrm{NO}$ consumption in the top layers of every soil ( $J_{\mathrm{NO}}=P_{\mathrm{NO}}-U_{\mathrm{NO}}$, Eq. 2 ). All parameters are known to calculate two-dimensional distributions of $P_{\mathrm{NO}}$ (as function of $\theta_{\mathrm{g}}$ and $T_{\text {soil }}$ ). The NO consumption rate $U_{\mathrm{NO}}$, however, is the product of the NO consumption rate coefficient $\left(k_{\mathrm{NO}}\right)$ and the chamber's headspace NO concentration ( $\left.=m_{\mathrm{NO} \text {, cham }} f_{\mathrm{C}, \mathrm{NO}}\right)$. While $m_{\mathrm{NO} \text {, cham }}$ is an intrinsic quantity of the applied chamber technique, it has a definite relevance for ambient (field) conditions. Generally, the NO flux across the soil-atmosphere interface is proportional to the difference between NO compensation point and atmospheric NO mixing ratios (cf. Galbally and Johansson, 1989), where the proportionality coefficient is the integral diffusion coefficient of the interface layer (which may be defined as the top soil layer) and the so-called quasi-laminar boundary layer (some few millimetres above soil surface). Since the well-mixed laboratory dynamic chamber is characterised by very high turbulent diffusion, measured data of $m_{\mathrm{NO}}$,cham are very close to those found at the top of the quasilaminar boundary layer in the field (cf. Pape et al., 2009). Using (temperature dependent) values of those $m_{\mathrm{NO}}$,cham which have been observed under zero-air fumigation at optimum 


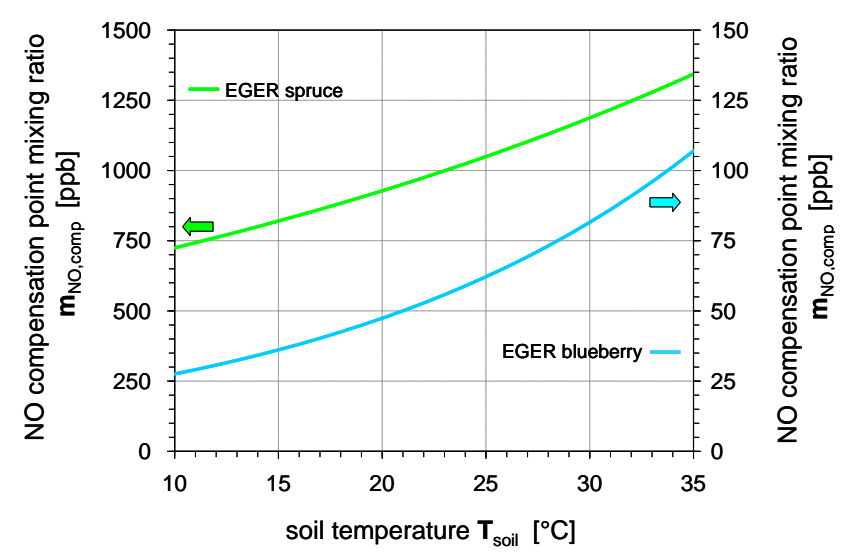

Figure 21. Soil temperature dependence of NO compensation point mixing ratio ( $\left.m_{\mathrm{NO}, \mathrm{comp}}\right)$ for EGER blueberry and EGER spruce samples. The curves have been calculated using the $P_{\mathrm{NO}}\left(\theta_{0}, T_{0}\right)$, $k_{\mathrm{NO}}\left(\theta_{0}, T_{0}\right), Q_{10 \_\mathrm{P}, \mathrm{NO}}$, and $Q_{10 \_\mathrm{U}, \mathrm{NO}}$ data listed in Table 2.

gravimetric soil moisture content, two-dimensional distributions of $U_{\mathrm{NO}}\left(\theta_{\mathrm{g}}, T_{\text {soil }}\right)$ have been calculated. In Figures 22 and 23, two-dimensional distributions of both, $P_{\mathrm{NO}}$ and $U_{\mathrm{NO}}$ are shown for the EGER blueberry and the KUCHE wheat soil sample, respectively.

Expressed by the (negatively) highest $k_{\mathrm{NO}}$ value of all investigated soils, the EGER blueberry soil has the highest potential to consume NO. However, $P_{\mathrm{NO}}$ values of this soil are comparatively low (2.07 and $3.79 \mathrm{ng} \mathrm{kg}^{-1} \mathrm{~s}^{-1}$ for $T_{\text {soil }}=20$ and $30^{\circ} \mathrm{C}$, respectively), chamber's headspace NO mixing ratios are also low (1.5 and $2.7 \mathrm{ppb}$ for $T_{\text {soil }}=20$ and $30^{\circ} \mathrm{C}$, respectively). Consequently, this results in $U_{\mathrm{NO}}$ values which are not exceeding $-0.12 \mathrm{ng} \mathrm{kg}^{-1} \mathrm{~s}^{-1}$ for all conditions of $\theta_{\mathrm{g}}$ and $T_{\text {soil }}$ (see Fig. 22). Obviously, this soil is characterised by well-balanced $P_{\mathrm{NO}}$ and $U_{\mathrm{NO}}$ resulting in low soil-atmosphere NO fluxes. In contrast, the $k_{\mathrm{NO}}$ value of the KUCHE wheat soil is only one third of the EGER blueberry soil; its potential to consume NO is correspondingly lower. However, maximum $U_{\mathrm{NO}}\left(-1.2 \mathrm{ng} \mathrm{kg}^{-1} \mathrm{~s}^{-1}\right)$ is about 10-fold higher than that of the EGER blueberry soil, which is caused by much higher values of $P_{\mathrm{NO}}$ and $m_{\mathrm{NO}}$,cham (see Table 2). For the KUCHE wheat soil fivefold higher $P_{\mathrm{NO}}$ values lead to 10 -fold higher $U_{\mathrm{NO}}$ values compared with the EGER blueberry soil, despite of lower $k_{\mathrm{NO}}$ values for the KUCHE wheat soil. In the field, where atmospheric turbulence causes strong vertical mixing within the lower troposphere, near-surface NO mixing ratios are of the order of a few ppb (or even fractions of ppb). Under these conditions, $U_{\mathrm{NO}}$ is expected to be quite low, and NO production will dominate the NO flux across the soil-atmosphere interface. Under very stable atmospheric conditions, which preferably occur within deep canopies, atmospheric turbulence might be very low or even be intermitting (e.g. Foken et al., 2012); then quite high NO mixing ratios (>10 ppb) could be present very close $(<3 \mathrm{~mm})$ to the soil surface facilitating enhanced impact of NO consumption to the NO flux.

\subsection{Soil temperature parameterisation of net potential NO fluxes - a caveat}

Using the algorithm of Galbally and Johansson (1989), the net potential NO flux from soil to the atmosphere (in units of $\mathrm{ng} \mathrm{m}^{2} \mathrm{~s}^{-1}$ ) is derived from observed $P_{\mathrm{NO}}$ and $k_{\mathrm{NO}}$ values, as well as from data of soil bulk density and effective soil diffusion coefficient of NO. Bargsten et al. (2102), Feig et al. (2008a), van Dijk et al. (2002), Yu et al. (2008, 2010), Kirkman et al. (2001), and Otter et al. (1999) parameterised the net potential NO flux with respect to soil temperature by applying a constant $Q_{10}$ value. This value has been determined as the ratio of optimum net NO release rates obtained under zero-air fumigation at $T_{\text {soil }}=30^{\circ} \mathrm{C}$ and $T_{\text {soil }}=20^{\circ} \mathrm{C}$, respectively (i.e. $Q_{10 \_\mathrm{J}, \mathrm{mNO}, \mathrm{in}_{-} 1 / 3}=J_{\mathrm{NO}}\left(\theta_{0}\right.$, $\left.\mathrm{T}_{1}, m_{\mathrm{NO}, \text { in_3,0 }}\right) / J_{\mathrm{NO}}\left(\theta_{0}, T_{0}, m_{\mathrm{NO}, \text { in_1, } 0}\right)$; see Table 2$)$. The NO mixing ratio in the chamber's headspace, $m_{\mathrm{NO}}$,cham, is usually in the range of a few tenths to a few ppb. Hence, the contribution of NO consumption (linearly increasing with $\left.m_{\mathrm{NO} \text {, cham }}\right)$ to the observed net NO release is rather small, and it is justified to assume $Q_{10 \_\mathrm{J}, \mathrm{mNO}, \mathrm{in} \_1 / 3}=Q_{10 \_\mathrm{P}, \mathrm{NO}}$. However, as (negatively) larger $k_{\mathrm{NO}}$ values (lower $m_{\mathrm{NO}}$,comp values) occur, as larger becomes the contribution of NO consumption to $J_{\mathrm{NO}}$, and the temperature dependence of $J_{\mathrm{NO}}$ is more and more determined by both, $Q_{10 \_ \text {P,NO }}$ and $Q_{10 \_ \text {U,NO. }}$. Whereas the number of samples is limited in our study, the attempt is made to estimate the potential impact of these find-

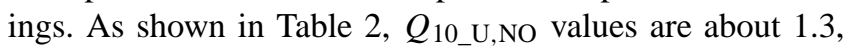
while corresponding $Q_{10 \_\mathrm{P}, \mathrm{NO}}$ values are consistently higher (1.44-2.03). This is equivalent to the fact that - with increasing soil temperature - NO production will increasingly dominate $\mathrm{NO}$ consumption, which in turn will lead to the increase of the net potential NO flux. However, verification of this effect, particularly by field experiments, is missing. A first indication, however, has been provided by the recent and comprehensive study of Laville et al. (2009). Performing both, laboratory and field measurements by chamber techniques on a mid-latitude fertilised agricultural soil, they have identified two different $Q_{10}$ values for the temperature dependence of their NO fluxes, namely $Q_{10}=4.3\left(0-20^{\circ} \mathrm{C}\right)$ and $Q_{10}=1.39\left(20-45^{\circ} \mathrm{C}\right)$.

It should be stated that non-consistent temperature response of NO net release rates and/or NO fluxes obviously require individual parameterisation of the temperature dependence of both, NO production and NO consumption. Largest impact is expected for fertilised soils and higher soil temperatures. 
EGER, blueberry covered midlatitude forest soil

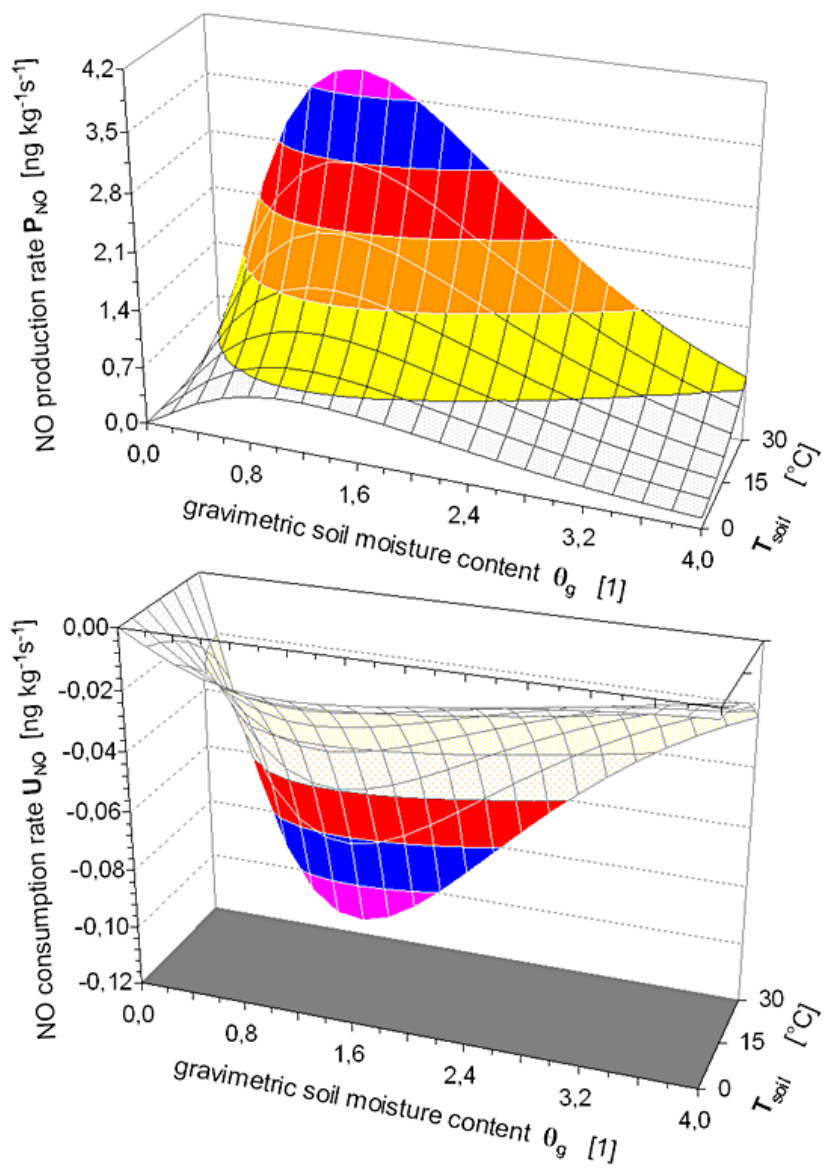

Figure 22. Two-dimensional illustration of NO production rate $P_{\mathrm{NO}}\left(\theta_{\mathrm{g}}, T_{\text {soil }}\right)$ and $\mathrm{NO}$ consumption rate $U_{\mathrm{NO}}\left(\theta_{\mathrm{g}}, T_{\text {soil }}\right)$ for the EGER blueberry soil. Light shaded areas represent $P_{\mathrm{NO}}$ and $U_{\mathrm{NO}}$ values which fall short of corresponding data rejection criteria (i.e. minimum detectable levels of $P_{\mathrm{NO}}$ and $U_{\mathrm{NO}}$; see Sect. 5.2). $P_{\mathrm{NO}}\left(\theta_{0}, T_{0}\right), k_{\mathrm{NO}}\left(\theta_{0}, T_{0}\right), Q_{10 \_\mathrm{P}, \mathrm{NO}}$, and $Q_{10} \_\mathrm{U}, \mathrm{NO}$ data listed in Table 2.

\subsection{Net release rates of acetone $\left(\mathrm{C}_{2} \mathrm{H}_{4} \mathrm{O}\right)$, acetaldehyde $\left(\mathrm{C}_{3} \mathrm{H}_{6} \mathrm{O}\right)$}

The improved laboratory dynamic chamber system was also used to measure net release rates of volatile organic compounds (VOC). Here, release rates of only two VOC compounds are shown, namely acetone $\left(\mathrm{C}_{2} \mathrm{H}_{4} \mathrm{O}\right)$ and acetaldehyde $\left(\mathrm{C}_{3} \mathrm{H}_{6} \mathrm{O}\right)$, because soil net release rates of VOCs (detectable by PTR-TOF-MS) are dominated by $\mathrm{C}_{2} \mathrm{H}_{4} \mathrm{O}$ and $\mathrm{C}_{3} \mathrm{H}_{6} \mathrm{O}$. Results of net $\mathrm{C}_{2} \mathrm{H}_{4} \mathrm{O}$ and $\mathrm{C}_{3} \mathrm{H}_{6} \mathrm{O}$ release rates from an arid, but agriculturally managed soil are shown in Figs. 15 and 16, respectively. Soil samples have been taken from the first $5 \mathrm{~cm}$ of a fertilised and irrigated cornfield of Kucha (Kuche) oasis, northern Taklimakan desert (Uighur Autonomous Region Xinjiang, P.R. China). Net $\mathrm{C}_{2} \mathrm{H}_{4} \mathrm{O}$ release rates fumigated with zero-air exhibit identical values

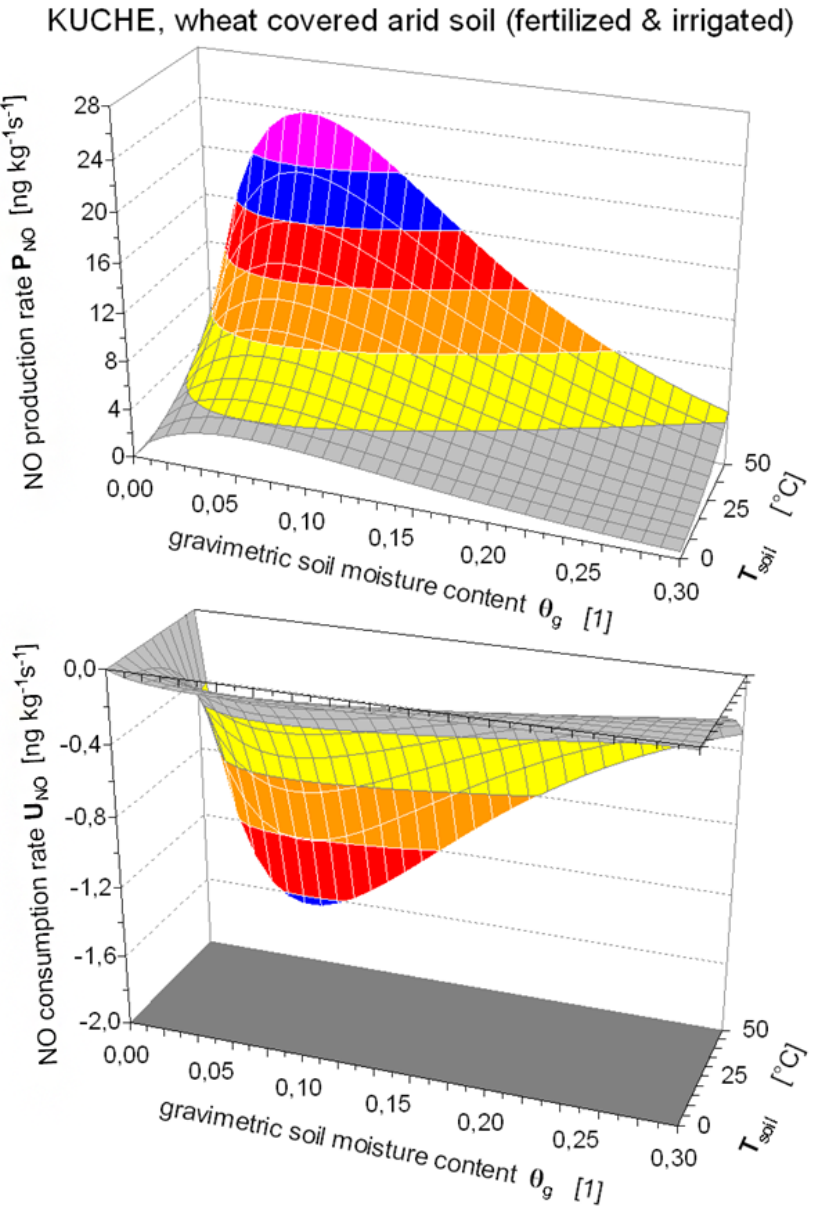

Figure 23. Two-dimensional illustration of NO production rate $P_{\mathrm{NO}}\left(\theta_{\mathrm{g}}, T_{\text {soil }}\right)$ and $\mathrm{NO}$ consumption rate $U_{\mathrm{NO}}\left(\theta_{\mathrm{g}}, T_{\text {soil }}\right)$ for the KUCHE wheat soil. Data have been calculated using $P_{\mathrm{NO}}\left(\theta_{0}, T_{0}\right)$, $k_{\mathrm{NO}}\left(\theta_{0}, T_{0}\right), Q_{10 \_\mathrm{P}, \mathrm{NO}}$, and $Q_{10 \_\mathrm{U}, \mathrm{NO}}$ data listed in Table 2.

of $\theta_{0}(0.027)$ and $\theta_{\mathrm{g}, 1}(0.10)$ at $T_{\text {soil }}=20^{\circ} \mathrm{C}$ as well as at $T_{\text {soil }}=30^{\circ} \mathrm{C}$ (see Fig. 15 ), while corresponding optimum net $\mathrm{C}_{3} \mathrm{H}_{6} \mathrm{O}$ release rates occur for $\theta_{0}=0.025$ and $\theta_{\mathrm{g}, 1}=0.08$ (see Fig. 16). For the entire range of gravimetric soil moisture, net $\mathrm{C}_{2} \mathrm{H}_{4} \mathrm{O}$ release rates are ca. double as much than $\mathrm{C}_{3} \mathrm{H}_{6} \mathrm{O}$ release rates. In both cases, net release rates are about 20-fold lower than those for nitric oxide. Remarkably, the shape of the $\theta_{\mathrm{g}}$-function of all three release rates is identical. Compared to the $J_{\mathrm{NO}}$ data; however, $\mathrm{C}_{2} \mathrm{H}_{4} \mathrm{O}$ and $\mathrm{C}_{3} \mathrm{H}_{6} \mathrm{O}$ data points own much larger errors. This is due to the fact that the make-up of corresponding zero air could not provide an incoming airstream which was $100 \%$ free

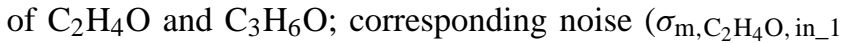

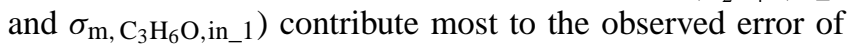

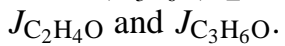

To our knowledge, net VOC release rates have been studied with respect to soil temperature (Asensio et al., 2007), but never for the entire range of gravimetric soil moisture content of soil samples. However, experimental proof for a release of 
VOCs by microbes in soil is very difficult. This is due to the fact that bacteria can lead to the increase of the net release of a certain VOC compound by indirect effects, e.g. increase in surface area (Schulz and Dickschat, 2007). Distinguishing between abiotic and biotic controls of net VOC release is surprisingly difficult since current methods for sterilising the soil can (i) affect the abiotically active moieties, and (ii) kill the organisms present. The analysis of an autoclaved reference sample is not recommended, since the process of autoclaving may cause the release VOCs (Schulz and Dickschat, 2007). Therefore, the possibility of abiotic release of $\mathrm{C}_{2} \mathrm{H}_{4} \mathrm{O}$ and $\mathrm{C}_{3} \mathrm{H}_{6} \mathrm{O}$ from soil particles - such as soil organic matter - cannot be excluded. However, it has been shown for the first time in this study that (at least) the net release of $\mathrm{C}_{2} \mathrm{H}_{4} \mathrm{O}$ and $\mathrm{C}_{3} \mathrm{H}_{6} \mathrm{O}$ follows the gravimetric soil moisture content in the form of an optimum curve, as it is generally observed for NO. This might point to biological processes responsible for the release of $\mathrm{C}_{2} \mathrm{H}_{4} \mathrm{O}$ and $\mathrm{C}_{3} \mathrm{H}_{6} \mathrm{O}$. Acetone was identified as an intermediate in aerobic acetylene metabolism (Kanner and Bartha, 1982). $\mathrm{C}_{3} \mathrm{H}_{6} \mathrm{O}$ is known as intermediate of fermentation (Jones and Woods 1986). From the results presented in Figs. 15 and 16, $Q_{10}$ values of $1.830 \pm 0.243$ for the release of $\mathrm{C}_{2} \mathrm{H}_{4} \mathrm{O}$ and $1.562 \pm 0.218$ for the release of $\mathrm{C}_{3} \mathrm{H}_{6} \mathrm{O}$ have been calculated. These values are in considerably good agreement with the $\mathrm{Q}_{10}$ values of net $\mathrm{NO}$ release rates in this study (data of $Q_{-} J$, mNO,in_1/3, see Table 2). This provides strong indication for microbial release of $\mathrm{C}_{2} \mathrm{H}_{4} \mathrm{O}$ and $\mathrm{C}_{3} \mathrm{H}_{6} \mathrm{O}$, because abiotic processes exhibit usually higher $\mathrm{Q}_{10}$ values (>3), as reported for the release of methyl chloride and methyl bromide from different plant materials (Yassaa et al., 2009; Wishkerman et al., 2008).

\subsection{Measurement of net $\mathrm{CO}_{2}$ release rates - a proxy for heterotrophic activity}

Net release rates for $\mathrm{CO}_{2}$ were measured in the static mode of the laboratory chamber system (see Sect. 3). Highest $J_{\mathrm{CO}_{2}}$ values have been observed from the organic-rich forest soils (5641 $\mathrm{ng} \mathrm{kg}^{-1} \mathrm{~s}^{-1}$ for EGER spruce; $2824 \mathrm{ng} \mathrm{kg}^{-1} \mathrm{~s}^{-1}$ for EGER blueberry), the lowest $J_{\mathrm{CO}_{2}}$ value, $105.6 \mathrm{ng} \mathrm{kg}^{-1} \mathrm{~s}^{-1}$ (in terms of C), has been calculated for the hyper-arid desert soil; however, statistically not different from zero, see Table 1 . Total organic carbon contents and $\mathrm{C} / \mathrm{N}$ ratios correlate well with $J_{\mathrm{CO}_{2}}$ (see Table 1). The described improved laboratory dynamic chamber system provides the facility to switch into the static chamber mode, which permits the measurement of net $\mathrm{CO}_{2}$ release rates $\left(J_{\mathrm{CO}_{2}}\right)$. For the organic-rich soils of this study, namely EGER spruce. EGER blueberry, and "SURINAME rainforest", $J_{\mathrm{CO}_{2}}$ values are 5641, 2824, and $417 \mathrm{ng} \mathrm{kg}^{-1} \mathrm{~s}^{-1}$ (in terms of C), respectively. These values are in a similar range as those for raw peat soils (Howard and Howard, 1993). According to Stark et al. (2002), soils which are characterised by high organic carbon contents and high $\mathrm{C}: \mathrm{N}$ ratios exhibit lower NO emissions. Following Dunfield and Knowles (1998), there is evidence that the organic carbon content of soil and the concomitant evolution of $\mathrm{CO}_{2}$ are good predictors for soil NO consumption. Gödde and Conrad (2000), found significant correlation between the NO consumption rate coefficient $\left(k_{\mathrm{NO}}\right)$ and the heterotrophic activity in the soil samples. This confirms our finding for the EGER blueberry soil, where high heterotrophic activity (indicated by high $J_{\mathrm{CO}_{2}}$ value) is related to high $k_{\mathrm{NO}}$, but low $P_{\text {NO }}$ values. The EGER spruce soil sample is contrasting; here its high $J_{\mathrm{CO}_{2}}$ value opposes a very high $J_{\mathrm{NO}}$. Our results indicate that the composition and degradability of organic matter might be of greater importance in driving both, the net $\mathrm{CO}_{2}$ release and the NO release, than the total $\mathrm{C}$ content alone. Therefore, total $\mathrm{C}$ content seems to be a good predictor for $J_{\mathrm{CO}_{2}}$, but not necessarily for $J_{\mathrm{NO}}$. Furthermore, it is certainly meaningful to assume that limited organic carbon contents of arid and hyper-arid soils result in very low (if any) NO consumption.

\section{Conclusions}

Obvious and large discrepancies have been found between the postulated response of net NO release rates to soil moisture, soil temperature, and NO mixing ratio and that observed by earlier versions of the laboratory dynamic chamber system. Therefore, an improved laboratory incubation system - consisting of six individual soil chambers - is described with respect to design and function, benchmark tests have been performed, and the overall performance of the system has been demonstrated by a series of experiments on five soil samples which are characterised by very contrasting soil properties. The methodical concept of the improved system is focussed on the precise measurement of NO mixing ratio (a) in the airstream flushing the soil chambers, and (b) in the chambers' headspace. The difference of these NO mixing ratios define the net NO release rate, from which a series of further quantities for the characterisation of NO production and consumption are derived (NO production rate, NO consumption rate coefficient, NO compensation point mixing ratio, $Q_{10}$ values of NO production and consumption). Finally, for calculation of all these quantities, a set of only four pairs of precisely measured NO mixing ratios is necessary. The actual gravimetric soil moisture content of each soil sample was precisely determined by a mass balance approach of the chamber's headspace water vapour concentration. The response of net NO release rates to soil temperature and NO mixing ratio has been studied by step-wise changing (i) the temperature of the entire chamber system, and (ii) using prescribed NO mixing ratios (from a standard gas diluting system). Proper control and automation of the chamber system with respect to these step-wise changes has been designed such that all experiments for characterisation of NO production and consumption could be performed on one soil sample and during one drying-out process only. Thorough quantification of the NO analyser's precision over a large range of 
NO mixing ratios ( 0.15 to $500 \mathrm{ppb}$ ) is substantial (a) to quantify corresponding errors of NO mixing ratio, (b) to enable quantitative error assessment of all derived quantities by consequent error propagation, (c) to establish significant, statistically based criteria, particularly limits of detection for all measured and derived quantities, and (d) to enable rigorous tests for data rejection.

Finally, it has been found that the NO compensation point mixing ratio of a given soil sample (defined as the quotient of $\mathrm{NO}$ production rate and NO consumption rate coefficient) is independent of the gravimetric soil moisture content, but explicitly on soil temperature, because NO production and NO consumption are characterised by different $Q_{10}$ values. As already reported by Gödde and Conrad (1999), there is strong evidence that the temperature dependence of the NO compensation point mixing ratio might be caused by different contribution of different microbial groups to the net release of NO, e.g. denitrifiers/nitrifiers or heterotrophs/autotrophs. With former versions of the laboratory dynamic chamber system these experiments have to be performed with four different sub-samples; corresponding sub-sample variability has been identified to lead quite often to non-consistent results, particularly of NO consumption rate coefficients and $Q_{10}$ values.

Only with the improved laboratory dynamic chamber system, which eliminates any effects of sub-sample variability, it was possible to show that the NO consumption rate coefficient of arid and hyper-arid soils is statistically indistinguishable from zero, but at least less than $-4 \times 10^{-7} \mathrm{~m}^{3} \mathrm{~kg}^{-1} \mathrm{~s}^{-1}$ (= minimum detectable limit). Using this minimum detectable limit, the NO compensation point mixing ratio would be $6590 \mathrm{ppb}$. From these result we hypothesise that (at least) in these hyper-arid soils the abundance of denitrifiers might be (very) low and denitrifiers even might lack the corresponding enzyme, NO reductase (NOR), which is used for detoxification of NO, or consumption of NO (cf. Falk et al., 2010). Then, it would be justified to assume that autotrophic nitrifier activity dominate biogenic NO emissions from drylands.

In order to study the impact of heterotrophic microbial activity on the net NO release, knowledge of a suitable proxy, the $\mathrm{CO}_{2}$ release, is important. Therefore, the improved laboratory dynamic chamber system has been extended by a facility which temporarily "switches" the system into the static chamber mode which has shown as necessary to measure net $\mathrm{CO}_{2}$ release rates. Using a PTR-TOF-MS in parallel to the $\mathrm{NO}_{\mathrm{x}}, \mathrm{CO}_{2}$, and $\mathrm{H}_{2} \mathrm{O}$ analysers, a first attempt has been made to determine net release rates of volatile organic compounds (VOCs) from soil samples. Surprisingly, net release rates of acetone $\left(\mathrm{C}_{2} \mathrm{H}_{4} \mathrm{O}\right)$ and acetaldehyde $\left(\mathrm{C}_{3} \mathrm{H}_{6} \mathrm{O}\right)$ share with $\mathrm{NO}$ identical shapes of optimum curves (with respect to gravimetric soil moisture), and $\mathrm{Q}_{10}$ values of the three compounds are also quite similar. These analogies between $\mathrm{NO}$ and $\mathrm{C}_{2} \mathrm{H}_{4} \mathrm{O} / \mathrm{C}_{3} \mathrm{H}_{6} \mathrm{O}$ strongly support the hypothesis that biological processes are responsible for the soil release of
$\mathrm{C}_{2} \mathrm{H}_{4} \mathrm{O}$ and $\mathrm{C}_{3} \mathrm{H}_{6} \mathrm{O}$ rather than abiotic processes. Knowledge of soil release rates of VOCs is of high interest for tropospheric chemistry, particularly for remote regions. Finally, complete characterisation of VOC production and VOC consumption with the improved laboratory dynamic chamber system may enable soil specific fingerprinting of corresponding microbial activities is certainly of great importance for the new emerging field of soil volatilomics.

\section{The Supplement related to this article is available online at doi:10.5194/bg-11-5463-2014-supplement.}

Acknowledgements. The authors want to thank the Max Planck Graduate Centre with Johannes Gutenberg-University Mainz (MPGC) and the MPG for their financial support. This work was part of the German Research Foundation (DFG) funded project "DEQNO - Desert Encroachment in Central Asia - Quantification of soil biogenic Nitric Oxide" (DFG-MA 4798/1-1) and has also been supported by the DFG research unit 763 (HALOPROC). Soil sampling has been supported by C. Becker, N. Hempelmann, M. Ermel, and G. Khorsha. We are grateful to Z. Wu, B. Kraft, and S. Thiele for fruitful discussions. Our deep gratitude goes to the "ancestors" of the laboratory dynamic chamber system (former versions): W. X. Yang, L. Otter, S. van Dijk, I. Trebs, M. Kortner, M. Welling, G. Feig, J. Yu, and A. Bargsten.

The service charges for this open access publication have been covered by the Max Planck Society.

Edited by: T. Laurila

\section{References}

Asensio, D., Penuelas, I. F., and Llusia, J.: On-line screening of soil VOCs exchange responses to moisture, temperature and root presence, Plant Soil, 291, 249-261, 2007.

Ashuri, F. A.: Der Austausch von Stickstoffmonoxid zwischen Boden und Atmosphäre unter besonderer Berücksichtigung des Bodenwassergehaltes, Einfluss kulturlandschaftlicher Verhältnisse auf den Umsatz eines Spurengases, PhD thesis, Johannes Gutenberg University Mainz, Germany, 1-169, 2009.

Bargsten, A., Falge, E., Pritsch, K., Huwe, B., and Meixner, F. X.: Laboratory measurements of nitric oxide release from forest soil with a thick organic layer under different understory types, Biogeosciences, 7, 1425-1441, doi:10.5194/bg-7-1425-2010, 2010.

Betlach, M. R. and Tiedje, J. M.: Kinetic Explanation for Accumulation of Nitrite, Nitric Oxide, and Nitrous Oxide During Bacterial Denitrification, Appl. Environ. Microbiol., 42, 1074-1084, 1981.

Braker, G. and Conrad, R.: Diversity, Structure, and Size of $\mathrm{N}_{2} \mathrm{O}$ Producing Microbial Communities in Soils - What Matters for Their Functioning?, Adv. Appl. Microbiol., 75, 33-70, 2011. 
Bronstein, I. N. and Semendjajew, K. A.: Taschenbuch der Mathematik, Empirische Formeln und Interpolation, 515-527. BSB B. G. Teubner Verlagsgesellschaft Leipzig, 1970.

Chameides, W. L., Fehsenfeld, F., Rodgers, M. O., Cardelino, C., Martinez, J., Parrish, D., Lonneman, W., Lawson, R., Rasmussen, R. A., Zimmerman, P., Greenberg, J., Middleton, P., and Wang, T.: Ozone Precursor Relationships in the Ambient Atmosphere, J. Geophys. Res., 97, 6037-6055, 1992.

Conrad, R.: Compensation concentration as critical variable for regulating the flux of trace gases between soil and atmosphere, Biogeochemistry, 27, 155-170, 1994.

Conrad, R.: Soil Microorganisms as controllers of atmospheric trace gases $\left(\mathrm{H}_{2}, \mathrm{CO}, \mathrm{CH}_{4}, \mathrm{~N}_{2} \mathrm{O}\right.$ and $\left.\mathrm{NO}\right)$, Microbiol. Rev., 60, 4, 609640, 1996

Crutzen, P. J., Lawrence, M., and Pöschl, U.: On the background photochemistry of tropospheric ozone, Tellus A-B, 51, 123-146, 1999.

Denman, K. L., Brasseur, G., Chidthaisong, A., Ciais, P., Cox, P. M., Dickinson, R. E., Hauglustaine, D. Heinze, C., Holland, E., Jacob, D., Lohmann, U., Ramachandran, S., da Silva Dias, P. L., Wofsy, S. C., and Zhang, X.: Couplings Between Changes in the Climate System and Biogeochemistry, in: Climate Change 2007: The Physical Science Basis, Contribution to Working Group I to the Fourth Assessment Report of the Intergovernmental Panel on Climate Change, 499-587, 2007.

Dunfield P. F. and Knowles, R.: Organic matter, heterotrophic activity, and NO consumption in soils, Glob. Change Biol., 4, 199207, 1998 .

Falk, S., Liu, B., and Braker, G.: Isolation, genetic and functional characterization of novel soil nirK-type denitrifiers, Syst. Appl. Microbiol., 33, 337-347, 2010.

Feig, G. T.: Soil Biogenic Emissions of Nitric Oxide from Arid and Semi-Arid Ecosystems, $\mathrm{PhD}$ thesis, Johannes Gutenberg University Mainz, Germany, 1-222, 2009.

Feig, G. T., Mamtimin, B., and Meixner, F. X.: Soil biogenic emissions of nitric oxide from a semi-arid savanna in South Africa, Biogeosciences, 5, 1723-1738, doi:10.5194/bg-5-17232008, 2008a.

Feig, G. T., Mamtimin, B., and Meixner, F. X.: Use of laboratory and remote sensing techniques to estimate vegetation patch scale emissions of nitric oxide from an arid Kalahari savanna, Biogeosciences Discuss., 5, 4621-4680, doi:10.5194/bgd-5-4621-2008, 2008b.

Foken, T., Meixner, F. X., Falge, E., Zetzsch, C., Serafimovich, A., Bargsten, A., Behrendt, T., Biermann, T., Breuninger, C., Dix, S., Gerken, T., Hunner, M., Lehmann-Pape, L., Hens, K., Jocher, G., Kesselmeier, J., Lüers, J., Mayer, J.-C., Moravek, A., Plake, D., Riederer, M., Rütz, F., Scheibe, M., Siebicke, L., Sörgel, M., Staudt, K., Trebs, I., Tsokankunku, A., Welling, M., Wolff, V., and Zhu, Z.: Coupling processes and exchange of energy and reactive and non-reactive trace gases at a forest site - results of the EGER experiment, Atmos. Chem. Phys., 12, 1923-1950, doi:10.5194/acp-12-1923-2012, 2012.

Garrido, F., Henault, C., Gaillard, H., Perez, H., and Germon, J. C.: $\mathrm{N}_{2} \mathrm{O}$ and $\mathrm{NO}$ emissions by agricultural soils with low hydraulic potentials, Soil Biol. Biochem., 34, 559-575, 2002.

Galbally, I. E. and Johansson, C.: A model relating laboratory measurements of rates of nitric oxide production and field measure- ments of nitric oxide emission from soils, J. Geophys. Res., 94, 6473-6480, 1989.

Galbally, I. E. and Roy, C. R.: Loss of fixed nitrogen from soil by nitric oxide exhalation, Nature, 275, 734-735, 1978.

Gelfand, I., Feig, G., Meixner, F. X., and Yakir, D.: Afforestation of semi-arid shrubland reduces biogenic NO emission from soil, Soil Biol. Biochem., 41, 1561-1570, 2009.

Gödde, M. and Conrad, R.: Simultaneous Measurement of Nitric Oxide Production and Consumption in Soil Using a Simple Static Incubation System, and the Effect of Soil Water Content on the Contribution of Nitrification, Soil Biol. Biochem., 30, 439-442, 1998.

Gödde, M. and Conrad, R.: Immediate and adaptational temperature effects on nitric oxide production and nitrous oxide release from nitrification and denitrification in two soils, Biol. Fertil. Soils, 30 , 33-40, 1999.

Gödde, M. and Conrad, R.: Influence of soil properties on the turnover of nitric oxide and nitrous oxide by nitrification and denitrification at constant temperature and moisture, Biol. Fertil. Soils, 32, 120-128, 2000.

Grauss, M., Müller, M., and Hansel, A.: High resolution PTR-TOF: quantification and formula confirmation of VOC in real time, $\mathrm{J}$. Am. Soc. Mass Sp., 21, 1037-1044, 2010.

Gubry-Rangin, C., Nicol, G. W., and Prosser, J. I.: Archaea rather than bacteria control nitrification in two agricultural acidic soils, FEMS Microbiol. Ecol., 74, 566-574, 2010.

Gut, A., Blatter, A., Farni, M., Lehmann, B. E., Neftel, A., and Staffelbach, T.: A new membrane tube technique (METT) for continuous gas measurements in soils, Plant Soil, 198, 79-88, 1998.

Howard, D. M. and Howard, P. J. A.: Relationships between $\mathrm{CO}_{2}$ evolution, moisture content and temperature for a range of soil types, Soil Biol. Biochem., 25, 1537-1546, 1993.

Insam, H. and Seewald, M. S. A.: Volatile organic compounds (VOCs) in soils, Biol. Fertil. Soils, 46, 199-213, 2010.

Jones, D. T. and Woods, D. R.: Acetone-Butanol Fermentation Revisited. Microbiological Reviews, 50, 484-524, 1986.

Kanner, D. and Bartha, R.: Metabolism of acetylene by Nocardia rhodochros, J. Bacteriol., 150, 989-992, 1982.

Kirkman, G. A., Yang, W. X., and Meixner, F. X.: Biogenic nitric oxide emissions upscaling: An approach for Zimbabwe, Global Biogeochem. Cy., 15, 1005-1020, 2001.

Koper, T. E., Stark, J. M., Habteselassie, M. Y., and Norton, J. M.: Nitrification exhibits Haldane kinetics in an agricultural soil treated with ammonium sulfate or dairy-waste compost, FEMS Microbiol. Ecol., 74, 316-322, 2010.

Kumon, Y., Sasaki, Y., Kato, I., Takaya, N., Shoun, H., and Beppu, T.: Codenitrification and Denitrification are dual metabolic Pathways through which dinitrogen evolves from nitrate in Streptomyces antibioticus, J. Bacteriol., 184, 2963-2968, 2002.

Laville, P., Flura, D., Gabrielle, B., Loubet, B., Fanucci, O., Rolland, M.-N., and Cellier, P.: Characterisation of soil emissions of nitric oxide at field and laboratory scale using high resolution method, Atmos. Environ., 43, 2648-2658, 2009.

Lindinger, W., Hansel, A., and Jordan, A.: Proton-transfer-reaction mass spectrometry (PTR-MS): On-line monitoring of volatile organic compounds at pptv levels, Chem. Soc. Rev., 27, 347-354, 1998. 
Ludwig, J., Meixner, F. X., Vogel, B., and Forstner, J.: Soil-air exchange of nitric oxide: An overview of processes, environmental factors, and modelling studies, Biogeochemistry, 52, 225-257, 2001.

MacDougall, D. and Crummett, W. B.: Guidelines for Data Acquisition and Data Quality Evaluation in environmental chemistry, Anal. Chem., 52, 2242-2249, doi:10.1021/ac50064a004, 1980.

Mayer, J. C., Bargsten, A., Rummel, U., Meixner, F. X., and Foken, T.: Distributed Modified Bowen Ratio method for surface layer fluxes of reactive and non-reactive trace gases, Agr. Forest Meteorol., 151, 655-668, 2011.

Meixner, F. X. and Yang, W. X.: Biogenic emissions of nitric oxide and nitrous oxide from arid and semiarid land, in: Dryland Ecohydrology, 233-255, Springer, Netherlands, 2006.

Müller, M., Graus, M., Ruuskanen, T. M., Schnitzhofer, R., Bamberger, I., Kaser, L., Titzmann, T., Hörtnagl, L., Wohlfahrt, G., Karl, T., and Hansel, A.: First eddy covariance flux measurements by PTR-TOF, Atmos. Meas. Tech., 3, 387-395, doi:10.5194/amt-3-387-2010, 2010.

Müller, M., George, C., and D'Anna, B.: Enhanced Spectral Analysis of C-TOF Aerosol Mass Spectrometer Data: Iterative Residual Analysis and Cumulative Peak Fitting, Int. J. Mass Spectrom., 306, 1-8, doi:10.1016/j.ijms.2011.04.007, 2011.

Müller, M., Mikoviny, T., Jud, W., D’Anna, B., and Wisthaler, A.: A New Software Tool for the Analysis of High Resolution PTR-TOF Mass Spectra, Chemometr. Intell. Lab., 127, 158-165, doi:10.1016/j.chemolab.2013.06.011, 2013.

Orlando, J., Caru, M., Pommerenke, B., and Braker, G.: Diversity and Activity of Denitrifiers of Chilean Arid Soil Ecosystems, Front. Microbiol., 3, 101, doi:10.3389/fmicb.2012.00101, 2012.

Otter, L. B., Yang, W. X., Scholes, M. C., and Meixner, F. X.: Nitric Oxide emissions from a southern African Savannah, J. Geophys. Res., 104, 18471-18485, 1999.

Pape, L., Ammann, C., Nyfeler-Brunner, A., Spirig, C., Hens, K., and Meixner, F. X.: An automated dynamic chamber system for surface exchange measurement of non-reactive and reactive trace gases of grassland ecosystems, Biogeosciences, 6, 405429, doi:10.5194/bg-6-405-2009, 2009.

Pennanen, T., Fritze, H., Vanhala, P., Kiikkila, O., Neuvonen, S., and Baath, E.: Structure of a Microbial Community in Soil after Prologed Addition of Low Levels of Simulated Acid Rain, Appl. Environ. Microbiol., 64, 2173-2180, 1998.

Remde, A., Slemr, F., and Conrad, R.: Microbial production and uptake of nitric oxide in soil, FEMS Microbiol. Ecol., 62, 221230, 1989.

Remde, A., Ludwig, J., Meixner, F. X., and Conrad, R.: A Study to Explain the Emission of Nitric Oxide from a Marsh Soil, J. Atmos. Chem., 17, 249-275, 1993.

Rudolph, J. and Conrad, R.: Flux between Soil and Atmosphere, Vertical Concentration Profiles in Soil, and Turnover of Nitric Oxide: 2. Experiments with Naturally Layered Soil Cores, J. Atmos. Chem., 23, 275-300, 1996.

Rudolph, J., Rothfuss, F., and Conrad, R.: Flux between Soil and Atmosphere, Vertical Concentration Profiles in Soil, and Turnover of Nitric Oxide: 1. Measurements on a Model Soil Core, J. Atmos. Chem., 23, 253-273, 1996.

Rütting, T., Boeckx, P., Müller, C., and Klemedtsson, L.: Assessment of the importance of dissimilatory nitrate reduction to am- monium for the terrestrial nitrogen cycle, Biogeosciences, 8 , 1779-1791, doi:10.5194/bg-8-1779-2011, 2011.

Saad, O. A. L. O. and Conrad, R.: Temperature dependence of nitrification, denitrification and turnover of nitric oxide in different soils, Biol. Fert. Soils, 15, 21-27, 1993.

Schulz, S. and Dickschat, J. S.: Bacterial volatiles: the smell of small organisms, Nat. Prod. Rep., 24, 814-842, 2007.

Schuster, M. and Conrad, R.: Metabolism of nitric oxide and nitrous oxide during nitrification and denitrification in soil at different incubation conditions, FEMS Microbiol. Ecol., 101, 133143, 1992.

Sillman, S.: The relation between ozone, NOx, and hydrocarbons in urban and polluted rural environments, Atmos. Environ., 33, 1821-1845, 1999.

Skopp, J., Jawson, M. D., and Doran, J. W.: Steady-State Aerobic Microbial Activity as a Function of Soil Water Content, Soil Sci. Soc. Am. J., 54, 1619-1625, 1990.

Slemr, F. and Seiler, W.: Field study of environmental variables controlling the NO emission from soil and the NO compensation point, J. Geophys. Res., 96, 13017-13031, 1991.

Stark, J. M., Smart, D. R., Hart, S. C., and Haubensack, K. A.: Regulation of nitric oxide emissions from forest and rangeland soils of Western North America, Ecology, 83, 2278-2292, 2002.

Steinkamp, J. and Lawrence, M. G.: Improvement and evaluation of simulated global biogenic soil NO emissions in an AC-GCM, Atmos. Chem. Phys., 11, 6063-6082, doi:10.5194/acp-11-60632011, 2011.

Stotzky, G., Goos, R. D., and Timonin, M. I.: Microbial changes occurring in soil as a result of storage, Plant Soil, 16, 1-18, 1962.

Titzmann, T., Graus, M., Müller, M., Hansel, A., and Ostermann, A.: Improved peak analysis of signals based on counting systems: Illustrated for proton-transfer-reaction time-of-flight mass spectrometry, Int. J. Mass Spectrom., 295, 72-77, 2010.

Thomson, B. C., Ostle, N. J., McNamara, N. P., Whiteley, A. S., and Griffiths, R. I.: Effects of sieving, drying and rewetting upon soil bacterial community structure and respiration rates, J. Microbiol. Meth., 83, 69-73, 2010.

UNEP: World Atlas of Desertification, Edward Arnold, Sevenoaks, 1-182, 1997.

Van Cleemput, O. and Samater, A. H.: Nitrite in soils: accumulation and role in the formation of gaseous $\mathrm{N}$ compounds, Fertilizer Res., 45, 81-89, 1996.

Van Dijk, S. and Meixner, F. X.: Production and consumption of NO in forest and pasture soils from the amazon basin, Water, Air, and Pollution: Focus, 1, 119-130, 2001.

Van Dijk, S. M., Gut, A., Kirkman, G. A., Meixner, F. X., Andreae, M. O., and Gomes, B. M.: Biogenic NO emissions from forest and pasture soils: Relating laboratory studies to field measurements, J. Geophys. Res., 107, 8058, doi:10.1029/2001JD000358, 2002.

Wang, R., Willibald, G., Feng, Q., Zheng, X., Liao, T. Brüggemann, N., and Butterbach-Bahl, K.: Measurement of $\mathrm{N}_{2}, \mathrm{~N}_{2} \mathrm{O}, \mathrm{NO}$ and $\mathrm{CO}_{2}$ Emissions from Soil with the Gas-Flow-Soil-Core Technique, Environ. Sci. Technol., 45, 6066-6072, 2011.

Wickland, K. P. and Neff, J. C.: Decomposition of soil organic matter from boreal black spruce forest: environmental and chemical controls, Biogeochemistry 87, 29-47, 2008. 
Williams, E. J., Hutchinson, G. L., and Fehsenfeld, F. C.: $\mathrm{NO}_{\mathrm{x}}$ and $\mathrm{N}_{2} \mathrm{O}$ emissions from soil, Global Biogeochem. Cy., 6, 351-388, 1992.

Wishkerman, A., Gebhardt, S., McRoberts, C. W., Hamilton, J. T. G., Williams, J., and Keppler, F.: Abiotic methyl bromide formation from vegetation and its strong dependence on temperature, Environ. Sci. Tech., 42, 6837-6842, 2008.

Wolff, V., Trebs, I., Foken, T., and Meixner, F. X.: Exchange of reactive nitrogen compounds: concentrations and fluxes of total ammonium and total nitrate above a spruce canopy, Biogeosciences, 7, 1729-1744, doi:10.5194/bg-7-1729-2010, 2010.

Yang, W. X. and Meixner, F. X.: Laboratory studies on the release of nitric oxide from sub-tropical grassland soils: The effect of soil temperature and moisture, in: Gaseous Nitrogen emissions from grasslands, 67-70, Wallingford, England, 1997.
Yassaa, N., Wishkerman, A., Keppler, F., and Williams, J.: Fast determination of methyl chloride and methyl bromide emissions from dried plant matter and soil samples using HS-SPME and GC-MS: method and first results, Environ. Chem., 6, 311-318, doi:10.1071/EN09034, 2009.

Yu, J., Meixner, F. X., Sun, W., Liang, Z., Chen, Y., Mamtimin, B., Wang, G., and Sun, Z.: Biogenic nitric oxide emission from saline sodic soils in a semiarid region, northeastern China: A laboratory study, J. Geophys. Res., 113, G04005, doi:10.1029/2007JG000576, 2008.

Yu, J., Meixner, F. X., Sun, W., Mamtimin, B., Wang, G., Qi, X., Xia, C., and Xie, W.: Nitric oxide emissions from black soil, northeastern China: A laboratory study revealing significantly lower rates than hiterto reported, Soil Biol. Biochem., 42, 1784$1792,2010$. 